CIBRARY

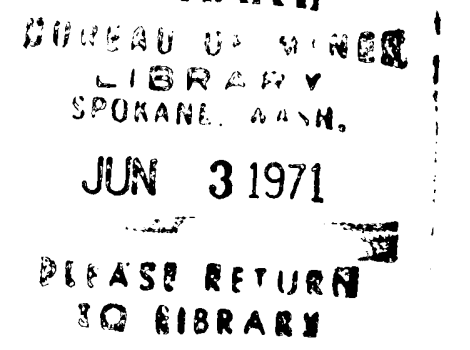

Los Angeles Basin

California-an

\title{
Introduction
}

GEOLOGIGAL SURVEY PROFESTIONAL PAPER 420-A
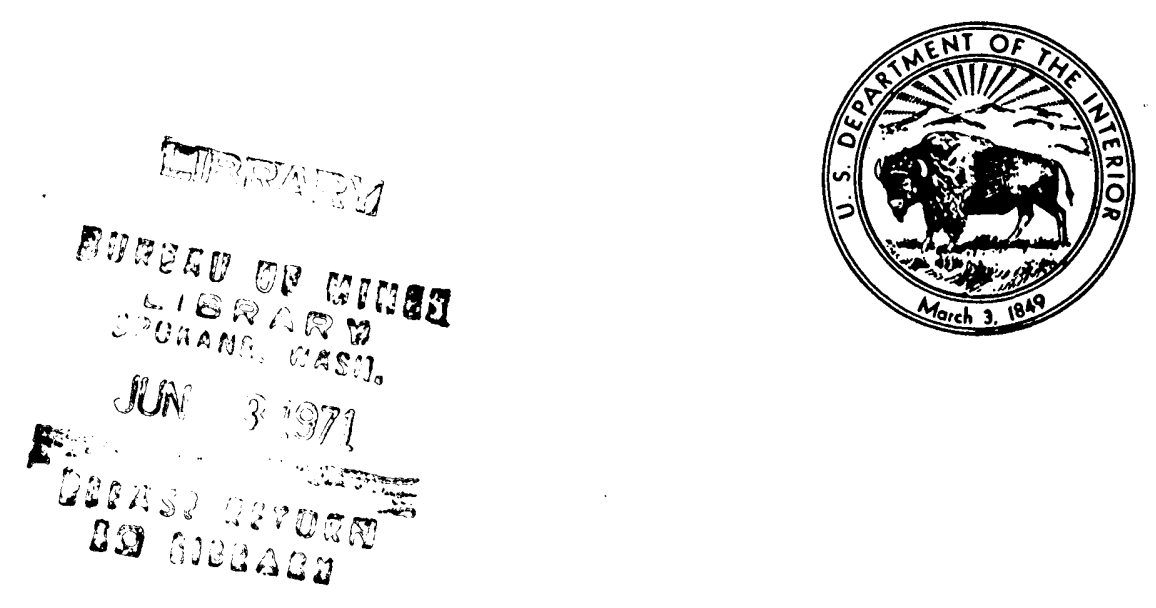
GEOLOGY OF THE LOS ANGELES BASIN 


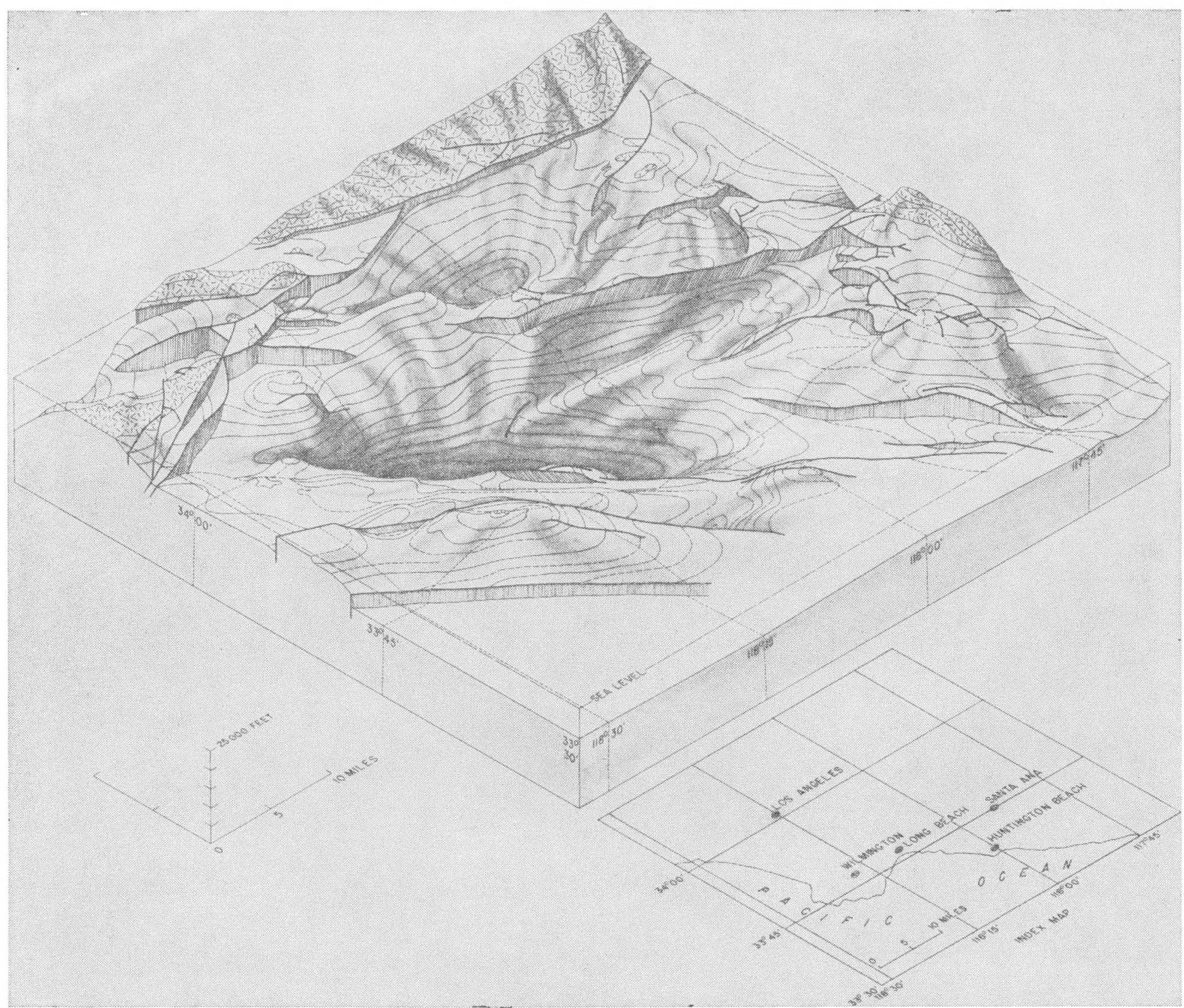

Isometric block diagram, basement surface of the Los Angeles basin. Contour interval is 1,000 feet; exposures of basement rocks are patterned; fault surfaces are hachured. 


\section{Geology of the}

\section{Los Angeles Basin}

\section{California-an}

\section{Introduction}

By R. F. YERKES, T. H. McCULLOH, J. E. SCHOELLHAMER, and J. G. VEDDER GEOLOGY OF THE EASTERN LOS ANGELES BASIN SOUTHERN CALIFORNIA

GEOLOGICAL SURVEY PROFESSIONAL PAPER 420-A

The evolution of a most prolific

oil district and the framework for

several detailed reports on its

geology and gravitational aspects

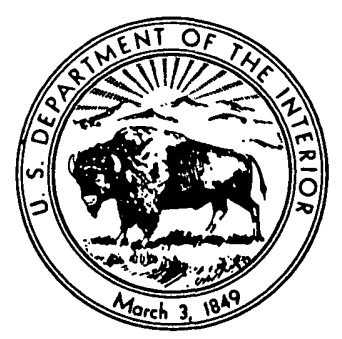

UNITED STATES GOVERNMENT PRINTING OFFICE, WASHINGTON: 1965 LIBRARY.

BUREAU OF MINES

LIBRARY SPOKANE. WASH.

JUN 31971 


\section{UNITED STATES DEPARTMENT OF THE INTERIOR \\ STEWART L. UDALL, Secretary \\ GEOLOGIGAL SURVEY \\ Thomas B. Nolan, Director}

For sale by the Superintendent of Documents, U.S. Government Printing Office Washington, D.C. 20402 


\section{CONTENTS}

Abstract

Introduction. . . . . .

Los Angeles basin-definition. . . . . . . . . . . . .

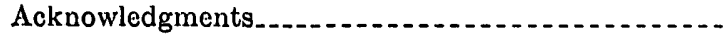

Stratigraphic nomenclature. . . . . . . . . . . . . .

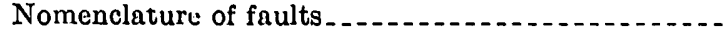

Bibliography of previous work

Regional setting of the basin

Peninsular Ranges province........................

Transverse Ranges province....................

Geographic and geologic elements of the basin . . . . .

Southwestern block. . .

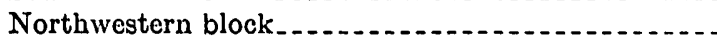

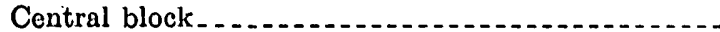

Northeastern block . . . . . .

Evolution of the basin

Predepositional phase-rocks of the basement complex.

Prebasin phase of deposition-Upper Cretaceous to lower Miocene rocks. . . . . . . .

Basin-inception phase-middle Miocene rocks.......

Principal phase of subsidence and deposition-upper Miocene to lower Pleistocene rocks............

Basin-disruption phase-upper Pleistocene to Recent strata - . - . -

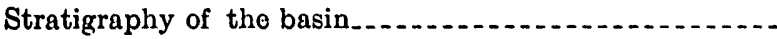

Basement rocks.

Southwestern block......................

Northwestern block. . . . . . . .

Central block................................

Northeastern block . . . . .

Superjacent rocks_...................

Upper Cretaceous rocks. . . . . . . . . . . . . . . .

Paleocene rocks

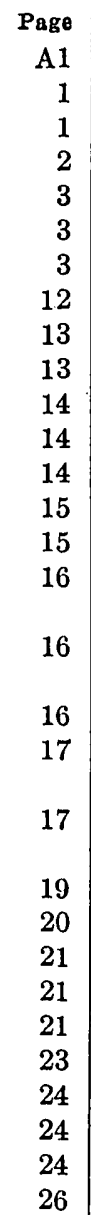

Page

Stratigraphy of the basin-Continued

Superjacent rocks-Continued

Eocene rocks.-.

Upper Eocene(?) to lower Miocene rocks.......

Middle Miocene rocks..........................

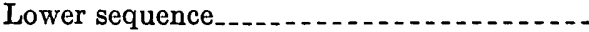

Upper sequence...........................

Intrusive rocks . . .

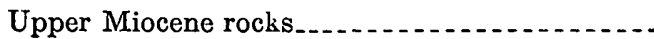

Eastern facies. .

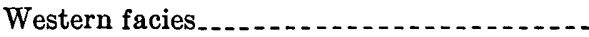

Intrusive rocks. . . . . .

Pliocene rocks.

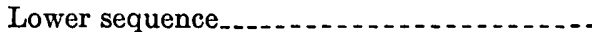

Upper sequence

Lower Pleistocene deposits...................

Upper Pleistocene deposits...............

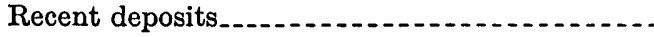

Structure of the basin

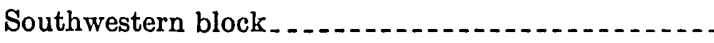

Newport-Inglewood zone of deformation ...........

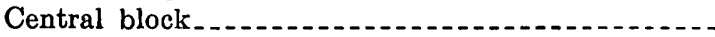

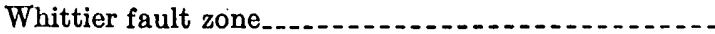

Northeastern block . . . . . . . . . . . . . . . . . . . . .

Santa Monica-Raymond Hill-Sierra Madre-Cuca-

monga fault zone.

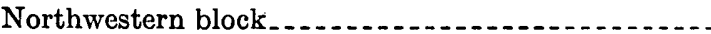

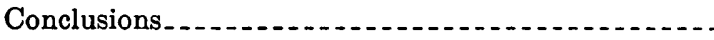

Oil in the basin

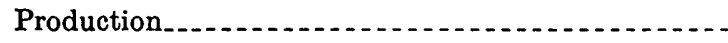

Occurrence

Reserves..............

References cited.
A28

28

30

32

34

34

34

37

37

37

38

41

44

$4 \dot{4}$

47

47

47

48

50

50

51

51

52

52

52

53

53

55

\section{ILLUSTRATIONS}

\section{[Plates are in pocket]}

Frontispiece. Isometric block diagram, basement surface of the Los Angeles basin.

Plate 1. Correlation chart of stratigraphic units, Los Angeles basin.

2. Diagram of composite sections, Los Angeles basin.

3. Panel diagram of the Los Angeles basin.

4. Generalized structure sections, Los Angeles basin.

Fiaune 1. Map of area covered by this investigation.

2. Map of major structural features and contours on the basement surface

basement surface

3. Key to major structural features...

4. Outline map of southern California showing geomorphic provinces 
FIGURE 5-11. Distribution maps of rock units:

5. Basement rocks.

6. Upper Cretaceous rocks.

7. Paleocene and Eocene rocks.

8. Upper Eocene(?) to lower Miocene rocks

9. Middle Miocene rocks.

10. Upper Miocene rocks

11. Lower Pliocene rocks

12. Map showing lithofacies and thickness relations of lower Pliocene rocks.

13. Diagram showing relation between thickness, water depth, and time during deposition of superjacent rocks.

14. Map showing distribution of upper Pliocene rocks.

\section{TABLES}

TABLE 1. Relation between thickness, water depth, and subsidence during deposition of the superjacent rocks in the deep part of the central block, Los Angeles basin . .

2. Crude-oil production data and estimated reserves and ultimate recovery for the Los Angeles basin and the State of California

3. Crude-oil production data and estimated reserves and ultimate recovery, by geologic age of reservoir rocks, for 46 known Los Angeles basin oil fields. 


\title{
GEOLOGY OF THE EASTERN LOS ANGELES BASIN, SOUTHERN CALIFORNIA
}

\section{GEOLOGY OF THE LOS ANGELES BASIN, GALIFORNIA-AN INTRODUGTION}

\author{
By R. F. Yerkes, T. H. McCulloh, J. E. Schoellhamer, and J. G. Vedder
}

\begin{abstract}
The present-day Los Angeles basin is a northwest-trending alluviated lowland plain about 50 miles long and 20 miles wide on the coast of southern California approximately between lat $33^{\circ} 30^{\prime}$ and $34^{\circ} \mathrm{N}$. and long $117^{\circ} 45^{\prime}$ and $118^{\circ} 30^{\prime} \mathrm{W}$. On the north, northeast, east, and southeast, the lowland plain is bounded by mountains and hills that expose Mesozoic or older basement rocks and sedimentary and igneous rocks of Late Cretaceous to late Pleistocene age.

The physiographic basin is underlain by a deep structural depression; the burled basement surface has relief of as much as 4.5 miles in a distance of 8 miles. Parts of this depression have been the sites of discontinuous deposition since Late Cretaceous time and of continuous subsidence and deposition since middle Mlocene time. In middle Miocene time this depositional basin extended well beyond the margins of the present-day physlographic basin. The term "Los Angeles basin" refers herein to the larger area.
\end{abstract}

The geology is described in terms of four primary structural blocks, which, in part, have contrasting basement rocks and superjacent sections and whose contacts are zones of faulting and flexure on which vertical and lateral movement has occurred intermittently since middle Miocene time.

The evolution of the basin is interpreted in five major phases, each of which is represented by a distinctive rock assemblage: the predepositional phase and basement rocks, the prebasin phase of deposition and Upper Cretaceous to lower Mlocene rocks, the basin-inception phase and middle Miocene rocks, the principal phase of subsidence and deposition and upper Mlocene to lower Pleistocene rocks, and the basin disruption phase and upper Pleistocene to Recent deposits.

As many as 13 successive marine platforms were cut into the seaward slopes of rising hills during late Pleistocene deformation. Upper Pleistocene strata in many parts of the basin have been elevated, arched, and locally overturned. Continuing deformation is indicated by warped Recent deposits, uplift and subsidence, and numerous earthquakes.

- The Los Angeles basin is California's most prolific oil-producing district in proportion to its size: at the end of 1961, its cumulative production $(5,035$ billion barrels) was nearly half that of Callfornia's. Petroliferous sediment accumulated rapidly in stagnant cool water more than 1,600 feet deep durIng the advancing and maximum phases of the last marine transgression, after which rapid fllling of the basin preserved the organic content of the sediment and provided load compression. Great thicknesses of intercalated source and reservoir rocks include numerous permeable conduits, through which the fluid hydrocarbons were expelled toward preexisting or developing structural traps.

\section{INTRODUCTION}

\section{LOS ANGELES BASIN-DEFINITION}

The present-day Los Angeles physiographic basin (index map, fig. 1) of coastal southern California is an alluviated lowland, sometimes called the coastal plain (Mendenhall, 1905, p. 11), which is bounded on the north by the Santa Monica Mountains and the Elysian, Repetto, and Puente Hills and on the east and southeast by the Santa Ana Mountains and San Joaquin Hills. The lowland surface slopes gently south or seaward, but it is interrupted by the Coyote Hills near the northeast margin, by a line of elongated low hills and mesas to the south and west that extends from Newport Bay northwest to Beverly Hills, and by the Palos Verdes peninsula at the southwest extremity.

The physiographic basin is underlain by a structural depression (figs. 2 and 3), parts of which have been the sites of discontinuous deposition since Late Cretaceous time and of continuous subsidence and chiefly marine deposition since middle Miocene time. The term "Los Angeles basin" is also used for this depositional basin, which in middle and late Miocene time extended northwestward to merge with the Ventura basin. The Miocene basin included the Santa Monica Mountains, the San Fernando Valley, the southern foothills of the San Gabriel Mountains, much of the northern Santa Ana Mountains, and the San Joaquin and Palos Verdes Hills. Unless specifically qualified, "Los Angeles basin" refers in this report to the larger area included in the middle and upper Miocene basin.

The Los Angeles basin is notable for its great structural relief and complexity in relation to its geologic youth and small size and for its prolific oil production. In this chapter of Professional Paper 420, the stratigraphy, structure, and geologic history of the basin are reviewed and the oil production, occurrence, and reserves are summarized; other chapters (see Durham and Yerkes, 1964) present detailed geologic studies of the eastern part of the basin and a basin-wide study 


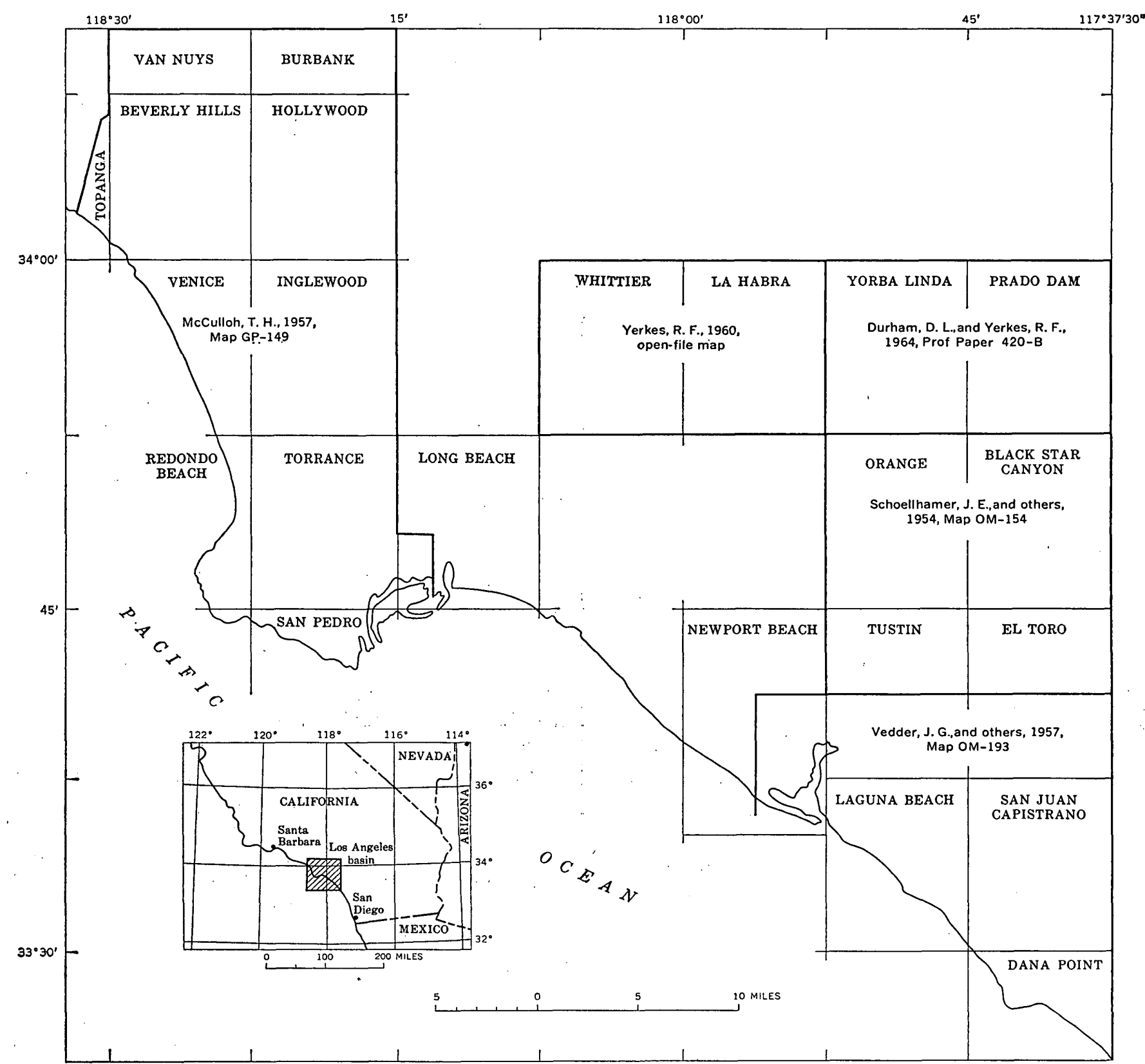

Figure 1.-Outline map of the Los Angeles basin. The areas covered by geologic maps of this investigation are bounded by the heavy lines, and names of pertinent 71/2-minute quadrangles are shown.

of the relation between observed and theoretical gravitational effects of the rocks and structural features (see fig. 1).

\section{ACKNOWLEDGMENTS}

This investigation was planned and initiated by A. O. Woodford, now of Pomona College, and we are most indebted to him for continued advice and criticism. W. P. Woodring contributed much geologic and paleontologic information. Many fossil identifications, ecologic interpretations, and faunal correla- tions were supplied by Ralph Stewart, M. C. Israelsky, and Patsy B. Smith of the U.S. Geological Survey; L. G. Hertlein of the California Academy of Sciences; W. P. Popenoe of the University of California at Los Angeles and the U.S. Geological Survey, and Theodore Downs of the Los Angeles County Museum. Assistance in analysis and interpretation of gravimetric data was given by C. E. Corbato of the University of California, G. P. Eaton of the University of California and U.S. Geological Survey, and D. R. Mabey of the U.S. Geological Survey. N. R. Smith of 
Pomona College aided in the design and construction of laboratory equipment and D. B. McIntyre and A. K. Baird of Pomona College aided in the interpretation of structural features in the field. D. L. Lamar of the Rand Corporation permitted the use of unpublished data. The manuscript greatly benefited from the suggestions of J. T. McGill, P. B. King, and R. H. Campbell of the U.S. Geological Survey. We are especially indebted to the many oil company employees who generously furnished valuable and significant surface and subsurface data.

During the period that $\mathrm{McCulloh}$ was a member of the staff of the University of California, he received important supplemental funds from the Institute of Geophysics at the Los Angeles campus, from the Intramural Research Committee at the Riverside campus, and from the Research Corporation of America.

\section{STRATIGRAPHIC NOMENCLATURE}

Owing in part to widespread lateral variations in lithology and thickness, the nomenclature of the superjacent succession of the Los Angeles basin includes several formal names for many units that are partly or wholly equivalent; for this reason the succession is here described informally in chronologic order. The classification of the Cenozoic is based on correlation of marine invertebrate faunas of western North America with those of the European standard section as proposed by Weaver and others (1944) and Durham (1954). Summaries of the formal stratigraphic nomenclature and brief descriptions of the rocks for selected areas of the basin are shown on the correlation chart (pl. 1) and on the diagram of composite sections (pl.2).

\section{NOMENOLATURE OF FAOLTS}

The names used herein for faults in the Los Angeles basin are largely well established; exceptions are discussed below. Priority and current usage were both considered in naming those exceptions. Because of established usage (Driver, 1948, p. 109; Barbat, 1958, p. 64) as well as priority (McLaughlin and Waring, 1914, p. 353), the name Santa Monica is used for the fault zone along the south margin of the Santa Monica Mountains rather than such other names as Hollywood (Hoots, 1931, p. 126) and Malibu Coast (Durrell, 1956, p. 3). Several names have been applied to different segments of this fault zone in areas east of the Santa Monica Mountains. The name Sierra Madre (Clark, 1930, pl. 16) is now frequently used for the segment of the zone that forms the frontal fault of the San Gabriel Mountains, although this segment was earlier figured and named San 708-887-65-2
Gabriel by English (1926, pl. 3). The name San Gabriel is now commonly applied to a fault zone within the mountain mass. The name Raymond Hill fault, in current use for the largely buried intervening segment of this fault zone, was first published by Johnson and Warren (1927). The easternmost segment of this fault zone, between the Sierra Madre and San Andreas fault zones, is named Cucamonga, after Eckis (1928).

Most early workers used the name Inglewood for the northwest-trending zone of deformation in the southwestern part of the basin. The more descriptive and preferred name Newport-Inglewood was introduced by Hoots (1931, p. 129) and is well established.

The fault along the northeastern margin of the Palos Verdes Hills was figured by several early workers (Ferguson and Willis, 1924, fig. 1; English, 1926, pl. 3) and was first named San Pedro by Clark (1930, pl. 16). Although lacking priority, the name Palos Verdes Hills fault (Schoellhamer and Woodford, 1951) is preferred for this feature because it is geographically more appropriate, and because the name "San Pedro" was once applied to a nearby, but separate, fault zone (Willis, 1938, fig. 1, p. 1018).

\section{BIBLIOGRAPEY OF PREVIOUS WORK}

The following selected annotated bibliography indicates the quantity and diversity of geologic work in the Los Angeles basin area. The papers were selected on the basis of their general applicability to parts of the basin or its margins, their basinwide significance, or their general historic interest. More comprehensive later papers were selected rather than an earlier report on the same topic. Abstracts succeeded by full reports on the same subject are omitted, as are most specialized reports on engineering geology, hydrology, paleontology, and physiography and reports on individual oil fields.

1856. Blake, W. P., General report on the geological collections [made on Whipple's reconnaissance near the 35th parallel from Fort Smith, Ark., to Los Angeles] : U.S. War Dept., Explor. and Surveys for Railroad, Mississippi River to Paciflc Ocean Repts., v. 3, pt. 4, no. 1, $164 \mathrm{p}$.

Describes fossil assemblages collected from (Palos Verdes?) sand at San Pedro, the Tertiary strata of the area, and the tar springs near Los Angeles (Rancho La Brea). Includes a strip map and section of the route showing the Los Angeles basin area.

1856. Blake, W. P., Observations on the physical geography and geology of the coast of California from Bodega Bay to San Diego: U.S. Coast Survey Rept. 1855, p. 376-398.

Describes the geology of the San Pedro area. 


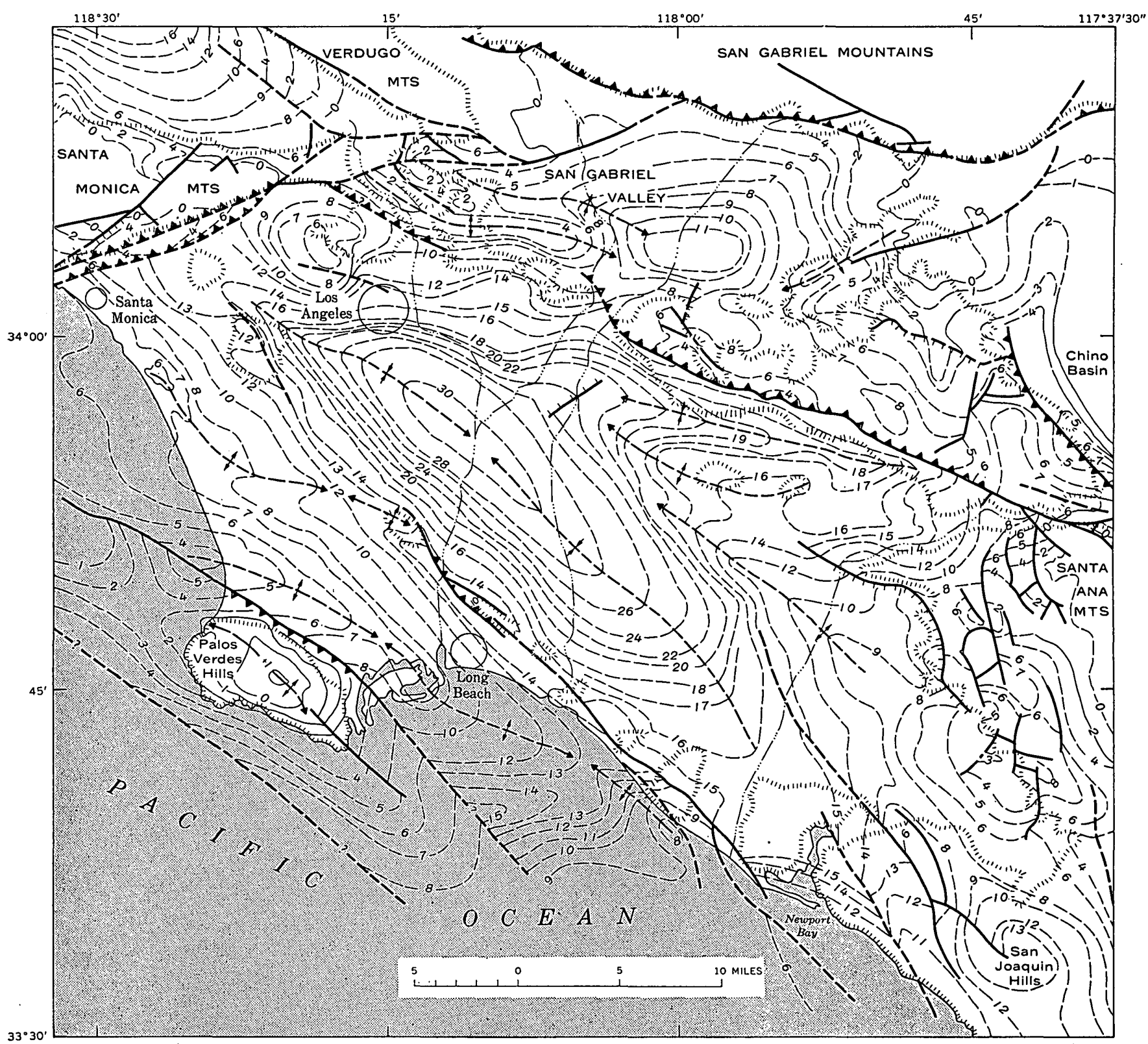

$33^{\circ} 30^{\prime}$

\section{EXPLANATION}
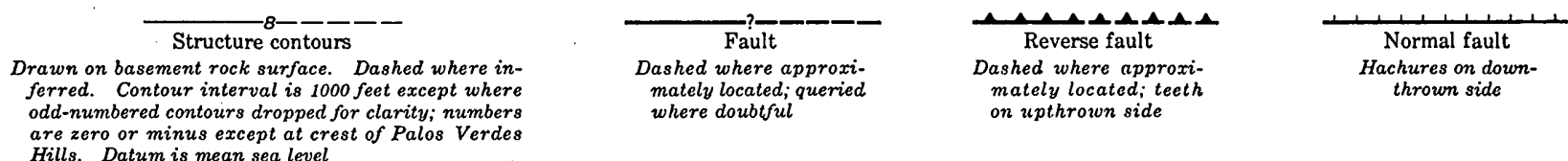
are zero or minus except at cre
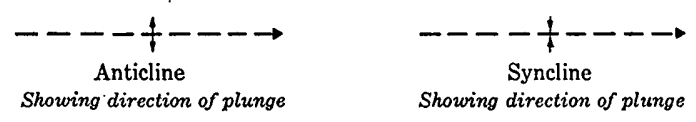

FIGURE 2.-Major structural features and structure contours on the basement surface of the Los Angeles basin. 


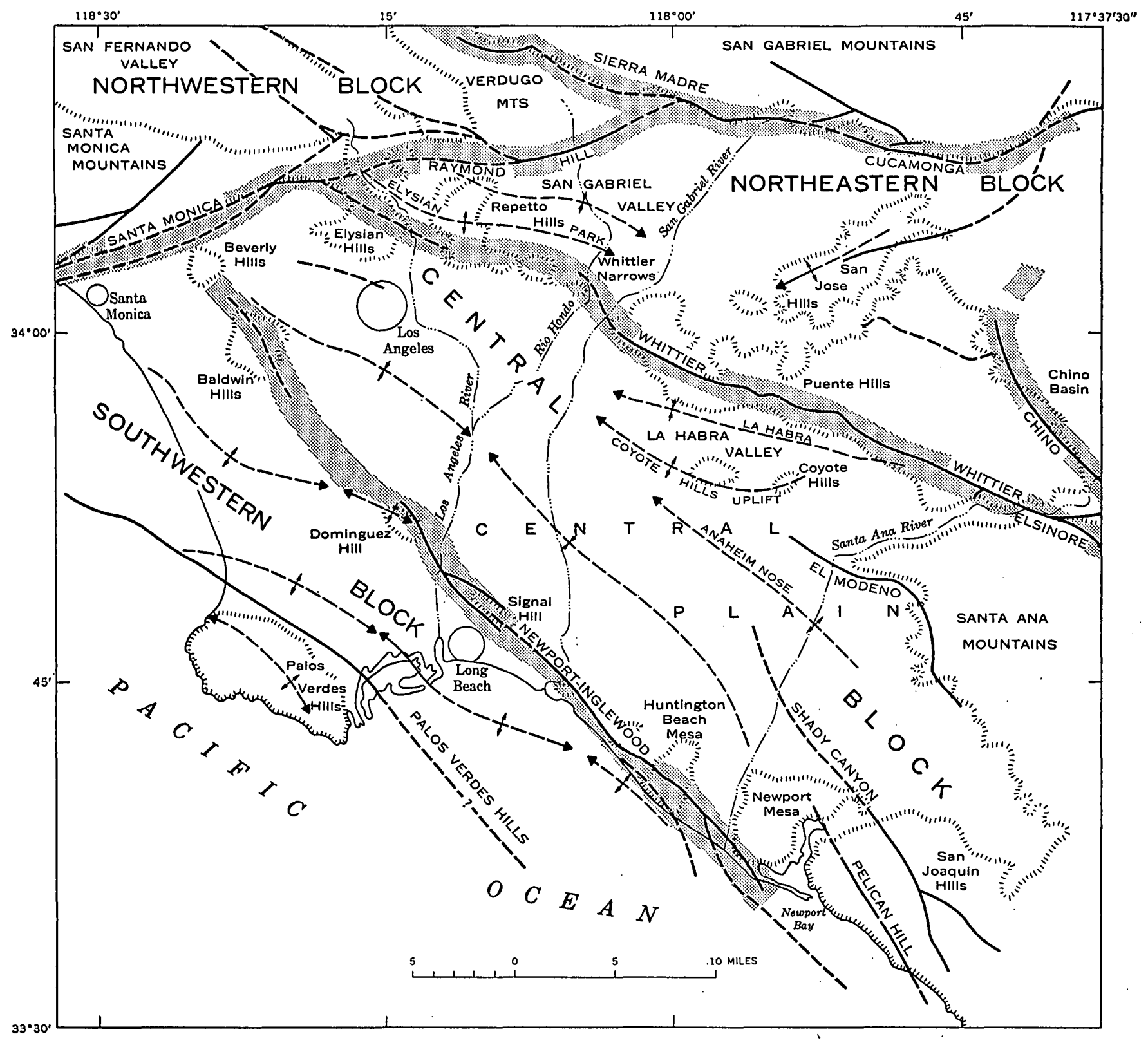

EXPLANATION

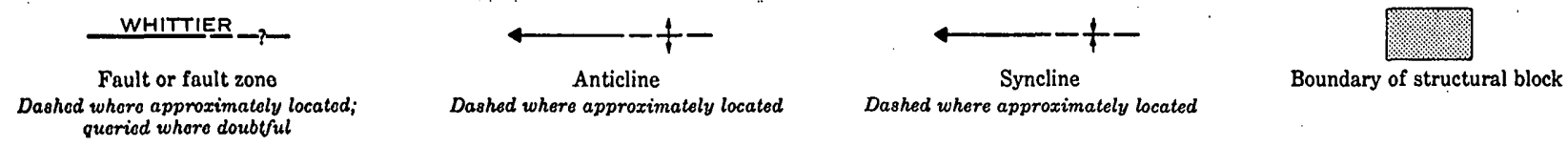

Fiaure 3.-Key to physiographic features, and major structural features on the basement surface, Los Angeles basin. 
1857. Antisell, Thomas, Geological report [Parke's surveys in California and near the 32d parallel]: U.S. War Dept., Explor. and Surveys for Railroad, Mississippi River to Pacific Ocean Repts., v. 7, pt. 2, 204 p. Describes geological observations in the Los Angeles area. Includes a map of Los Angeles basin area, scale 1 inch to 24 miles.

1857. Blake, W. P., Geological report [Williamson's reconnaissance in California] : U.S. War Dept., Explor. and Surveys for Railroad, Mississippi River to Pacific Ocean Repts., v. 5, pt. 2, 370 p.

Includes numerous geographical and geological observations in the Los Angeles and San Pedro areas. A geological map at end of report shows coastal southern California, scale 1 inch to about 30 miles.

1865. : Whitney, J. D., Report of progress and synopsis of the fieldwork from 1860 to 1864: California Geol. Survey, Geology, v. 1, 498 p.

Describes oil possibilities of areas in coastal California covered by the "bituminous slate formation of Tertiary age" (Monterey Shale) and geological observations of the Santa Monica, San Gabriel, and Santa Ana Mountains. Notes the uses of tar from the springs (Rancho La Brea) west of Los Angeles and that the springs contain bones of entrapped cattle and birds.

1888. Goodyear, W. A., Los Angeles County: California Mining Bur., 8th Ann. Rept. State Mineralogist, p. 335342.

Describes the Miocene and Pliocene strata of the San Juan Capistrano area and nearby parts of the Santa Ana Mountains in the southeastern part of the Los Angeles basin.

1890. Bowers, Stephen, Orange County: California Mining Bur., 10th Ann. Rept. State Mineralogist, p. 399-409.

A generalized description of the geography and geology of the Santa Ana Mountains-San Joaquin Hills area and detailed local observations. Recognizes the presence of Miocene and Cretaceous strata in the area and lists about 60 Upper Cretaceous and Tertiary fossils presumably identified by Bowers.

1893. Fairbanks, H. W., Geology of San Diego County; also of portions of Orange and San Bernardino Counties: California Mining Bur., 11th Ann. Rept. State Mineralogist, p. 76-120.

Describes geologic observations in the northwestern Santa Ana Mountains (p. 114-118). Map shows Cretaceous strata and volcanic rocks of that area.

1893. Lawson, A. C., The post-Pliocene diastrophism of the coast of southern California: California Univ., Dept. Geology Bull., v. 1, no. 4, p. 115-160.

The marine terraces of Palos Verdes Hills are described, and their relative youth is recognized. Fossiliferous strata referred to the Pliocene by Lawson are now considered to be lower Pleistocene.

1897. Watts, W. L., Oil and gas yielding formations of Los Angeles, Ventura, and Santa Barbara Counties: California Mining Bur. Bull. 11, p. 1-72.

A brief description of the geology of Los Angeles County and a list of oil wells and their production.
Introduces the name Sespe Formation. For present usage, see 1924 entry for Kew.

1901. Watts, W. L., Oll and gas yielding formations of Callfornia: California Mining Bur. Bull. 19, 236 p.

One of the earliest systematic geologic reports on the Puente Hills-San Joaquin Hills area. Includes geologic maps, scale 1 inch to 2 miles. Notes the occurrence of glaucophane schist breccia and intrusive rocks in coastal areas. Includes fossil lists (p. 218-224) for Cretaceous, Tertiary, and Quaternary strata. Fossils were identified by J. C. Merriam.

1902. Arnold, Delos, and Arnold, Raiph, The marine Pliocene and Pleistocene stratigraphy of the coast of southern California: Jour. Geology, v. 10, p. 117-138.

Describes the Pleistocene strata of the San Pedro area and proposes the terms "lower San Pedro series" (San Pedro Sand) and "upper San Pedro series" (Palos Verdes Sand and nonmarine deposits on lowest emergent terrace).

1903. Arnold, Ralph, The paleontology and stratigraphy of the marine Pliocene and Pleistocene of San Pedro, Callfornia: California Acad. Sci. Mem., v. 3, 420 p.

This monograph on the Pleistocene strata of the San Pedro area established that section as the :standard for California by demonstrating its faunal succession. Shows how marine Pleistocene sequences can be correlated on the basis of warm- or cool-water types in their faunal assemblages. Arnold's Pliocene is now considered to be lower Pleistocene.

1905. Mendenhall, W. C., Development of underground waters in the eastern coastal plain region of southern California: U.S. Geol. Survey Water-Supply Paper 137, $140 \mathrm{p}$.

This and the following two papers form a baslc reference on ground water of the Los Angeles basin area; they name and describe some of the geomorphic features of the basin area.

1905. Mendenhall, W. C., Development of underground waters in the central coastal plain region of southern California: U.S. Geol. Survey Water-Supply Paper 138, $162 \mathrm{p}$.

1905. Mendenhall, W. C., Development of underground waters in the western coastal plain region of southern Callfornia: U.S. Geol. Survey Water-Supply Paper 139, $105 \mathrm{p}$.

1907. Eldridge, G. H., and Arnold, Ralph, The Santa Clara Valley, Puente Hills, and Los Angeles oll districts, southern California: U.S. Geol. Survey Bull. 309, $266 \mathrm{p}$.

Earliest publication of detailed geologic mapping in Los Angeles basin area by U.S. Geological Survey. Recognizes Whittier fault zone (pl. 11) and introduces the terms Fernando, Puente, and Modelo Formations. Includes a geologic map, scale 1:62,500.

1908. Mendenhall, W. C., Ground waters and irrigation enterprises in the foothill belt, southern California: U.S. Geol. Survey Water-Supply Paper 219, 180 p.

Describes the geography and physiography of the northern margin of the basin area and includes a brief account of geological and structural features. 
1914. Dickerson, R. E., The Martinez and Tejon Eocene and assoclated formations of the Santa Ana Mountains: Californla Univ., Dept. Geology Bull., v. 8, p. 257A274A.

Describes a blostratigraphic study of northwestern Santa Ana Mountains; recognizes faunal zones in the Upper Cretaceous sequence, Paleocene and Eocene strata, and two divisions of the Miocene on the basis of fossils. Includes a map, scale 1 inch to 2 miles.

1914. McLaughlin, R. P., and Waring, C. A., Petroleum industry of Callfornia: Callfornia Mining Bur. Bull. 69, 519 p., map follo.

The map follo contains a brief summary of the general stratigraphy and small-scale geologic maps of parts of Los Angeles basin area.

1916. Packard, E. L., Faunal studies in the Cretaceous of the Santa Ana Mountains of southern California: California Univ., Dept. Geology Bull., v. 9, p. 137-159.

Descrlbes and names the Trabuco Formation. Correlates Santa Ana Mountains Cretaceous fauna with that of the Chico Formation of Chico Creek in central California. Recognizes three faunal zones and describes new species of mollusks.

1923. Kew, W. S. W., Geologlc evidence bearing on the Inglewood earthquake of June 21, 1920: Seismol. Soc. America Bull., v. 13, p. 155-158.

Describes the geology of the Baldwin Hills (Inglewood oil field area) and the evidence for an active fault at depth (evidently the earliest reference to Newport-Inglewood fault zone).

1923-24. Eaton, J. E., Structure of Los Angeles basin and environs: Oll Age, v. 20 , no. 6, p. 8-9, 52 (1923); v. 21, no. 1, p. 16-18, 52, 54 (1924).

Maps and names the Newport-Beverly Hills fault zone (Newport-Inglewood zone) and hypothesizes that the series of en echelon anticlines that mark its trend was formed as a result of predominantly lateral movement along a deep-seated fracture. Applies same reasoning to the structures along the Whittler fault zone. Includes the earliest reference to the Anaheim nose (p. 52).

1924. Ferguson, R. N., and Willis, C. G., Dynamics of oil-field structure in southern California: Am. Assoc. Petroleum Geologists Bull., v. 8, no. 5, p. 576-583.

Illustrates in analytical detail the hypothesis that the en echelon anticlines along the Inglewood (Newport-Inglewood) zone are due to lateral shearing at depth. Includes a small-scale map that shows and names the major faults of the basin area.

1924. Kew, W. S. W., Geology and oll resources of a part of Los Angeles and Ventura counties, California: U.S. Geol. Survey Bull. 753, 202 p.

Although concerned primarily with an area north of the Santa Monica Mountains, this report describes the Topanga Formation (named in 1923) and establishes the present-day usage of the term Sespe Formation.

1924. Woodford, A. O., The Catalina metamorphic facles of the Franciscan series: California Univ., Dept. Geol. Scl. Bull., จ. 15, no. 3, p. 49-68.
Describes and names the glaucophane-bearing schists exposed on Santa Catalina Island and in the Palos Verdes Hills.

1925. Woodford, A. O., The San Onofre breccia; its nature and origin: California Univ., Dept. Geol. Sci. Bull., v. 15 , no. 7 , p. $159-280$.

Describes the San Onofre Breccia as a facies of the Temblor (Topanga) Formation and postulates a source and possible mode of deposition. Introduces term Capistrano Formation for a Miocene (?) sequence in the San Joaquin Hills area. Includes a geologic map of vicinity of Capistrano, scale 1 inch to 2 miles.

1926. Eaton, J. E., A contribution to the geology of Los Angeles basin, California: Am. Assoc. Petroleum Geologists Bull., v. 10 , no. 8 , p. $753-767$.

An amplification of the theory published in 1924. Includes the earliest geologic map of the basin area that shows the Tertiary sequence subdivided.

1926. English, W. A., Geology and oil resources of the Puente Hills region, southern, California, with a section on the chemical character of the oil, by P. W. Prutzman: U.S. Geol. Survey Bull. 768, 110 p.

Includes the first detailed map of the Whittler fault zone and the earliest large-scale map of Puente Hills-northern Santa Ana Mountains area, scale $1: 62,500$.

1926. Tieje, A. J., The Pliocene and Pleistocene history of the Baldwin Hills, Los Angeles County, California : Am. Assoc. Petroleum Geologists Bull., v. 10, no. 5, p. 502512.

Describes the upper Pliocene and Pleistocene sequence of Baldwin Hills (Inglewood oil field) and the evidence for very late Pleistocene uplift of the hills. Introduces term Palos Verdes Sand for the upper part of the marine Pleistocene and restricts the older name San Pedro to the lower part.

1927. Johnson, H. R., and Warren, V. C., Geological and structural conditions of the San Gabriel Valley region: California Div. Water Rights Bull. 5, p. 73-100.

Includes a generalized description of landforms and geology of the San Gabriel Valley and its margins. Introduces term Raymond Hill fault for the central, largely buried segment of the northern boundary fault of the present-day Los Angeles basin.

1927. Vickery, F. P., The interpretation of the physiography of the Los Angeles coastal belt [Callfornia]: Am. Assoc. Petroleum Geologists Bull., v. 11, no. 4, p. 417424.

Describes the relations between "anticlinally warped surfaces" (along the Newport-Inglewood zone) and the underlying petroliferous structural features and traces their physiographic development. Recognizes as antecedent such streams as the Los Angeles River and Coyote Creek, which crosses the Coyote Hills uplift.

1928. Vickery, F. P., Geology of the Los Angeles basin: Oil Bull., v. 14, no. 4, p. 355-361.

One of the earliest comprehensive syntheses of the stratigraphy and structure of the Los Angeles basin. Includes a description of the structural environment and geologic age of the oil measures. 
1930. Hill, M. L., Structure of the San Gabriel Mountains north of Los Angeles, Callfornia: Callfornia Univ., Dept. Geol. Sci. Bull., v. 19, no. 6, p. 137-170.

Describes the structure and fault mechanics of part of the south margin of the San Gabriel Mountains, which are shown to have been uplifted in Pliocene or post-Pliocene time along north-dipping reverse faults.

1930. Stock, Chester, Rancho La Brea; a record of Pleistocene life in California: Los Angeles Mus. Pub. 1, $82 \mathrm{p}$.

A comprehensive and well-illustrated account of the fossil forms that have been collected from the asphalt pits at Rancho La Brea. Includes an exhaustive bibliography.

1931. Grant, U. S., 4th, and Gale, H. R., Catalogue of the marine Pliocene and Pleistocene Mollusca of California and adjacent regions: San Diego Soc. Nat. History Mem., v. 1; $1036 \mathrm{p}$.

Part 1 (by Gale) includes a discussion of the stratigraphy and temperature facies of the marine Pleistocene formations in the San Pedro area.

1931. Hoots, H. W., Geology of the eastern part of the Santa Monica Mountains, Los Angeles County, California : U.S. Geol. Survey Prof. Paper 165-C, p. 83-134.

Earliest detailed map and systematic description of the geology of the eastern Santa Monica Mountains.

1932. Gale, H. S., ed., Southern California, in Internat. Geol. Cong., 16th, Washington, D.C., 1933, Guidebook 15, Excursion C-1: 68 p.

Contains nine papers on the geology, stratigraphy, and oil development of the Los Angeles basin area by Gale, Hoots, Kew, Reed, Stock, and Woodring. Hoots and Kew present a small-scale geologic map (pl. 6) of the basin area that is more detailed than any previously published.

1932. Loel, Wayne, and Corey, W. H., The Vaqueros formation, lower Miocene of California; [pt.] I, Paleontology: California Univ., Dept. Geol. Sci. Bull., v. 22, no. 3, p. 31-410.

A comprehensive monograph on the marine invertebrate faunas of the Vaqueros Formation throughout California and their regional correlation and zonal distribution. Includes chapters on the assemblages from the Santa Ana Mountains-San Joaquin Hills area and the Santa Monica Mountains.

1932. Soper, E. K., and Grant, U. S., 4th, Geology and paleontology of a portion of Los Angeles, California: Geol. Soc. America Bull., v. 43, no. 4, p. 1041-1067.

Describes the geology of downtown Los Angeles area and includes a map, scale 1 inch to about 1,000 feet. Discusses Pliocene molluscan faunas and their correlation.

1933. Eaton, J. E., Long Beach, California, earthquake of March 10, 1933: Am. Assoc. Petroleum Geologists Bull., v. 17, p. 732-738.

Describes the geology of the Newport-Inglewood zone, to which the earthquake is attributed. About 1 mile of post-Miocene right-lateral offset is postulated.
1933. Reed, R. D., Geology of Callfornia : Tulsa, Okla., Am. Assoc. Petroleum Geologists, 355 p.

Discusses petrologic, paleogeographic, and other features of formations in southern California. A basic reference work on the interpretation of geologic history of California.

1934. Eckis, Rollin, Geology and ground water storage capacity of valley fill-South coastal basin investigation: California Div. Water Resources Bull. 45, 279 p.

Contains much data concerning the geologic history of the Los Angeles basin area and the largest scale $(1: 142,560)$ geologic map to date (1934) of the basin and its borders.

1934. Miller, W. J., Geology of the western San Gabriel Mountains of California: California Univ., Pub. Math. and Phys. Sci., v. 1, p. 1-114.

Earliest systematic report on an area in the western San Gabriel Mountains that includes an anorthositic complex now known to be Precambrian in age.

1936. Gutenberg, Beno, and Buwalda, J. P., Seismic reflection profile across Los Angeles basin [abs.]: Geol. Soc. America Proc. 1935, p. 327-328.

Source of the often-quoted statement that the base ment surface is at minus 45,000 feet in the central part of the Los Angeles basin. Actually states that the "** * deepest reflections occur at a maximum depth of 13-14 km (45,000 feet) south of Bellflower beneath the synclinal axis in the upper formations ***."

1936. Reed, R. D., and Hollister, J. S., Structural evolution of southern California: Am. Assoc. Petroleum Geologists Bull., v. 20, no. 12, p. 1529-1704.

Describes the geologic and structural history of southern California. Includes an extended discussion of the Newport-Inglewood zone and a comprehensive tectonic map of southern California, scale $1 \mathrm{inch}$ to 8 miles.

1937. Oakeshott, G. B., Geology and mineral deposits of the western San Gabriel Mountains, Los Angeles County: California Jour. Mines and Geology, v. 33, p. 215-249.

General geology of an area in the western San Gabriel Mountains that contains an anorthositic complex now known to be Precambrian in age.

1937. Popenoe, W. P., Upper Cretaceous Mollusca from southern California: Jour. Paleontology, v. 11, no. 5, p. 379402.

First publication of the stratigraphic nomenclature now in use for the Upper Cretaceous strata of the northern Santa Ana Mountains.

1938. Kleinpell, R. M., Miocene stratigraphy of California: Tulsa, Okla., Am. Assoc. Petroleum Geologists, $450 \mathrm{p}$. Includes discussion of the Miocene strata of the Los Angeles basin area, their correlation, and their foraminiferal faunas and stages.

1938. Woodring, W. P., Lower Pliocene mollusks and echinoids from the Los Angeles basin, California, and their inferred environment: U.S. Geol. Survey Prof. Paper 190, $67 \mathrm{p}$.

Discusses 27 fossil forms from the lower Pliocene strata of the basin area and their inferred habitat. 
Includes an outline of the geology of the basin and a generallzed small-scale geologic map.

1939. Grant, U. S., 4th, and Sheppard, W. E., Some recent changes of elevation in the Los Angeles basin of southern California, and their possible significance: Selsmol. Soc. America Bull., v. 29, no. 2, p. 299-326.

Describes the changes in surface elevation of parts of western Los Angeles basin as determined from lines of repeated first-order leveling. First published account in which subsidence of oil flelds in the Los Angeles area is ascribed to withdrawal of fluids.

1042. Popenoe, W. P., Upper Cretaceous formations and faunas of southern Callfornla: Am. Assoc. Petroleum Geologists Bull., v. 26, no. 2, p. 162-187.

Describes Upper Cretaceous strata and faunas and thelr subdivislons in the Santa Ana and Santa Monica Mountains of the Los Angeles basin and in the Siml Hills to the northwest.

1943. Jenkins, O. P., ed., Geologic formations and economic development of the oil and gas fields of Callfornia : Callfornia Div. Mines Bull. 118, 773 p.

Includes 34 papers, by 28 authors, on geology and oll flelds of the Los Angeles basin area.

1943. Wissler, S. G., Stratigraphic formations [relations] of the producing zones of the Los Angeles basin oil flelds: Callfornia Div. Mines Bull. 118, p. 209-234.

Includes a useful correlation chart and a description of stratigraphy and lithology of the ofl-producing strata.

1945. Woodford, A. O., Shelton, J. S., and Moran, T. G., Geology and oll possibilities of Puente and San Jose Hills, Callfornia, 1944: U.S. Geol. Survey Oil and Gas Inv. Prellm. Map 23, scale 1 inch to about 1 mile.

Planlmetric geologic map of the Puente and San Jose Fills north of the Whittier fault zone. Includes a brlef description of the stratigraphy, structure, and foraminiferal faunas.

1945. Woodring, W. P., and Popenoe, W. P., Paleocene and Eocene stratigraphy of northwestern Santa Ana Mountains, Orange County, Californla: D.S. Geol. Survey Oll and Gas Inv. Prelim. Chart 12.

Presents stratigraphic sections, scale 1 inch to 150 feet, of the Paleocene and Eocene strata exposed along the eastern margin of the Los Angeles basin, which served as basis for defining and renaming units in the succession.

1946. Bramlette, M. N., The Monterey formation of California and the origin of its siliceous rocks: U.S. Geol. Survey Prof. Paper 212, $57 \mathrm{p}$.

Describes the stratigraphy and lithology of selected sections of Miocene strata correlated with the Monterey (Shale) Formation, including sections in southeastern Puente Hills, Palos Verdes Hills, and southeastern San Joaquin Hills.

1946. Shelton, J. S., Geologic map of northeast margin of San Gabriel Basin, Los Angeles County, California : U.S. Geol. Survey Oll and Gas Inv. Prellm. Map 63, scale 1 inch to 2,000 feet.

Geologic map of the Miocene Glendora Volcanics in the northeastern corner of the Los Angeles basin.
1946. White, J. L., The schist surface of the western Los Angeles basin: California Div. Oll and Gas, Summ. Operations, California Oil Fields, v. 32, no. 1, p. 3-11. Describes and maps the configuration of part of the Catalina Schist basement that underlies the coastal area of the western Los Angeles basin as known from drill holes. Suggests (p. 10) that the Newport-Inglewood zone marks the eastern boundary of the schist.

1946. Woodford, A. O., Moran, T. G., and Shelton, J. S., Miocene conglomerates of Puente and San Jose Hills, California: Am. Assoc. Petroleum Geologists Bull., v. 30, no. 4, p. 514-560.

Describes the composition, petrology, and provenance of the numerous conglomerate beds in the Miocene strata of the northeastern Los Angeles basin and their inferred paleogeography.

1946. Woodring, W. P., Bramlette, M. N., and Kew, W. S. W., Geology and paleontology of Palos Verdes Hills, Callfornia: U.S. Geol. Survey Prof. Paper 207, 145 p.; map, scale 1 inch to 2,000 feet.

This study of the Palos Verdes Hills is a basic reference to the Pleistocene stratigraphy and history of the Los Angeles basin. Includes a comprehensive annotated bibliography. Introduction includes a brlef summary of Los Angeles basin stratigraphy.

1948. Alf, R. M., A mylonite belt in the southeastern San Gabriel Mountains, California: Geol. Soc. America Bull., v. 59, no. 11, p. 1101-1119.

Geology and petrography of several thick bands of dense crush rock of probable Mesozoic age. An amplification of a 1943 paper that first reported the mylonites.

1948. Driver, H. L., Genesis and evolution of Los Angeles basin, California: Am. Assoc. Petroleum Geologists Bull., v. 32, no. 1, p. 109-125.

A systematic description of the structural evolution of the basin. Includes an extensive bibliography.

1948. Larsen, E. S. Jr., Batholith and associated rocks of Corona, Elsinore, and San Luis Rey quadrangles, southern California: Geol. Soc. America Mem. 29, $182 \mathrm{p}$.

Monograph on the petrography and petrology of the batholithic rocks.

1948. Parkin, E. J., Vertical movement in the Los Angeles region, 1906-1946: Am. Geophys. Union Trans., v. 29, no. 1, p. 17-26.

Describes areas in the southern part of the basin, most of which are shown to have subsided on the basis of several first-order levelings by the U.S. Coast and Geodetic Survey.

1949. Daviess, S. N., and Woodford, A. O., Geology of the northwestern Puente Hills, Los Angeles County, Callfornia: U.S. Geol. Survey Oil and Gas Inv. Prelim. Map 83, scale 1 inch to 1,000 feet.

A large-scale map of the western Puente Hills north of the Whittier fault zone. Includes a brief summary of the stratigraphy, structure, and paleontology.

1949. Gilluly, James, Distribution of mountain bullding in geologic time: Geol. Soc. America Bull., v. 60, no. 4, p. 561-590.

Includes descriptions of local uplifts in the Los Angeles basin area as revealed by leveling. 
1949. Gilluly, James, and Grant, U.S., 4th, Subsidence in the Long Beach Harbor area, California: Geol. Soc. America Bull., v. 60 , no. 3, p. 461-529.

A description and analysis of pronounced local subsidence attributed to withdrawal of ofl from underlying strata.

1950. Olmsted, F. H., Geology and oil prospects of western San Jose Hills, Los Angeles County, California : California Jour. Mines and Geology, v. 46, no. 2, p. 191212.

Describes the stratigraphy and structure of part of the San Jose Hills.

1951. Schoellhamer, J. E., and Woodford, A. O., The floor of the Los Angeles basin, Los Angeles, Orange, and San Bernardino Counties, California: U.S. Geol. Survey Oil and Gas Inv. Map OM-117, scales 1 inch to 1 mile and 1 inch to 2 miles.

Names, describes, and illustrates the configuration of the buried basement (Catalina Schist) surface of the area southwest of the Newport-Inglewood zone. Includes aeromagnetic profiles and structure sections of inland parts of the basin. Contains a summary of the stratigraphy and structure of the basin area.

1952. Kundert, C. J., Geology of the Whittier-La Habra area, Los Angeles County, California: California Div. Mines Spec. Rept. 18, 22 p.

Geology of an area in the southwestern Puente Hills south of the Whittier fault zone is shown.

1952. Richmond, J. F., Geology of Burruel Ridge, northwestern Santa Ana Mountains, California: California Div. Mines Spec. Rept. 21, 16 p.

A detailed description of an area in the northwesternmost Santa Ana Mountains that is underlain largely by upper Miocene strata.

1952. White, R. T. (chm.), and others, Cenozoic correlation section across Los Angeles basin from Palos Verdes Hills to San Gabriel Mountains, California: Am. Assoc. Petroleum Geologists, Pacific Sec., scale 1 inch to 1,000 feet vertical and 1 inch to 5,000 feet horizontal.

A stratigraphic and structural correlation section across the Torrance, Dominguez, and Montebello ofl fields.

1952. Woodring, W. P., Pliocene-Pleistocene boundary in California Coast Ranges: Am. Jour. Sci., v. 250, no. 6, p. $401-410$.

The basis for drawing the boundary for the Los Angeles basin is the marked faunal discontinuity at the base of the Lomita Marl and Timms Point Silt in the San Pedro area. Includes a correlation chart and list of extinct and locally extinct genera and subgenera in late Pliocene and Pleistocene formations of California.

1953. Neuerberg, G. J., Geology of the Griffith Park area, Los Angeles County, California: California Div. Mines Spec. Rept. 33, 29 p.

Describes the geology of an area in the eastern Santa Monica Mountains.
1954. Jahns, R. H., ed., Geology of southern Callfornia : California Div. Mines Bull. 170, 10 chapters, 5 guidebooks, 34 map sheets.

A symposium on the geology and mineral resources of southern California, including contributions by 103 authors. The following apply especially to the Los Angeles basin area :

Bailey, T. L., and Jahns, R. H., Geology of the Transverse Range province, southern Callfornia: Chap. 2, p. 83-106.

Corey, W. H., Tertiary basins of southern Callfornia: Chap. 3, p. 73-83.

Durham, J. W., The marine Cenozoic of southern Callfornia : Chap. 3, p. 23-31.

Durham, J. W., Jahns, R. H., and Savage, D. E., Marine-nonmarine relationships in the Cenozoic section of California: Chap. 3, p. 59-71.

Durrell, Cordell, Geology of the Santa Monica Mountains, Los Angeles and Ventura Counties: Map sheet 8, scale 1 inch to about 2 miles.

Gray, C. H., Jr., Geology of the Corona-ElsinoreMurrieta area, Riverside County: Map sheet 21 , scale 1 inch to 3 miles.

Hill, M. L., Tectonics of faulting in southern California : Chap. 4, p. 5-13.

Jahns, R. H., Geology of the Peninsular Range province, southern California and Baja California : Chap. 2, p. 29-52.

Natland, M. L., and Rothwell, W. T., Jr., Fossil Foraminifera of the Los Angeles and Ventura regions, California: Chap. 3, p. 33-42.

Parker, F. S., Origin, migration, and trapping of oil in southern California: Chap. 9, p. 11-19.

Popenoe, W. P., Mesozoic formations and faunas, southern California and northern Baja California [Mexico]: Chap. 3, p. 15-21.

Shelton, J. S., Miocene volcanism in coastal southern California: Chap. 7, p. 31-36.

Woodford, A. O., Schoellhamer, J. E., Vedder, J. G., and Yerkes, R. F., Geology of the Los Angeles basin: Chap. 2, p. 65-81.

1954. Schoellhamer, J. E., Kinney, D. M., Yerkes, R. F., and Vedder, J. G., Geologic map of the northern Santa Ana Mountains, Orange and Riverside Counties, Callfornia: U.S. Geol. Survey Oil and Gas Inv. Map OM-154, scale $1: 24,000$.

Map of the western slope of the northern Santa Ana Mountains. Names and describes members of the El Modeno Volcanies and the Puente Formation.

1955. Menard, H. W., Deformation of the northeastern Pacific basin and the west coast of North America: Geol. Soc. America Bull., v. 66, no. 9, p. 1149-1198.

Describes the Murray fracture zone, a primary structural feature of the northeastern Pacific basin, as the offshore continuation of the Transverse Range province, and discusses its possible origin by plastic deformation of the crust.

1955. Shelton, J. S., Glendora volcanic rocks, Los Angeles basin, California: Geol. Soc. America Bull., v. 66, no. 1 , p. 45-89.

Geology, petrography, composition, and age of a thick sequence of middle Miocene volcanic rocks in the northeastern part of the Los Angeles basin. 
1955. Kundert, C. J., compiler, Geologic map of California, Long Beach, Los Angeles, and Santa Ana sheets: Callfornia Div. Mines, scale $1: 250,000$.

Preliminary uncolored edition of three maps, with separate explanatory sheets, that cover the Los Angeles basin area.

1956. Moody, J. D., and Hill, M. J., Wrench-fault tectonics : Geol. Soc. America Bull., v. 67, no. 9, p. 1207-1246.

Includes an analysis of the Newport-Inglewood zone. Indicates that right-lateral movement is shown by the orientation of the associated fold axes.

1956. Poland, J. F., Piper, A. M., and others, Ground-water geology of the coastal zone, Long Beach-Santa Ana area, Callfornia: U.S. Geol. Survey Water-Supply Paper 1109, 162 p.

Map of surface geology of the coastal area between the Palos Verdes and San Joaquin Hills and a description of the water-bearing strata; map scale $1: 31,680$.

1957. McCulloh, T. H., Simple Bouguer gravity and generallzed geologic map of the northwestern part of the Los Angeles basin, California: U.S. Geol. Surrey Geophys. Inv. Map GP-149, scale 1:48,000.

First published detalled gravity map of part of the basin area. Includes a summary of the general geology and discusses the correlation between Bouguer anomalles and geologic structure.

1057. Vedder, J. G., Yerkes, R. F., and Schoellhamer, J. E., Geologic map of the San Joaquin Hills-San Juan Capistrano area, Orange County, California: U.S. Geol. Survey Oil and Gas Inv. Map OM-193, scale 1: 24,000 .

This geologic map of the southeastern part of the Los Angeles basin is the first published record of Paleocene and Eocene strata in the north-central part of the hills. Demonstrates the stratigraphic sequence and facies relations in middle Mlocene and younger strata.

1957. Yerkes, R. F., Volcanic rocks of the El Modeno area, Orange County, Callfornia: U.S. Geol. Survey Prof. Paper 274-L, p. 313-334.

Describes the geology, petrography, and age of a sequence of middle Miocene volcanic rocks on the western slope of the northern Santa Ana Mountains.

1958. Barbat, W. F., The Los Angeles basin area, California, in $\mathrm{A}$ guide to the geology and oil flelds of the Los Angeles and Ventura reglons, Am. Assoc. Petroleum Geologists, Ann. Mtg., Mar. 1958, p. 37-49. Also in Weeks, L. G., ed., Habitat of oil-a symposium: Tulsa, Okla., Am. Assoc. Petroleum Geologists, p. 62-77.

A comprehensive synthesis of the structural evolution of the Los Angeles basin and a discussion of the factors that favored development of the petroleum deposits.

1958. Higgins, J. W., ed., A guide to the geology and oil flelds of the Los Angeles and Ventura regions: Am. Assoc. Petroleum Geologists, Pacific Sec., 204 p.
Includes the following previously unpublished papers of a general nature, besides road logs and reports on 12 Los Angeles basin oil fields by 14 authors:

Conrey, B. L., Depositional and sedimentary patterns of lower Pliocene-Repetto rocks in the Los Angeles basin : p. 51-54

Eaton, G. P., Miocene volcanic activity in the Los Angeles basin : p. 55-58.

Jahns, R. H., The geologic framework of Southern California : p. 1-15

1958. Larsen, E. S., Jr., Gottfried, David, Jaffe, H. W., and Waring, C. L., Lead-alpha ages of the Mesozoic batholiths of western North America: U.S. Geol. Survey Bull. 1070-B, p. 35-62.

Determinations on 25 samples of rocks from the southern California batholith give a mean age of $110 \pm 13$ million years. Geologic evidence indicates an early Late Cretaceous age.

1959. Durham, D. L., and Yerkes, R. F., Geologic map of the eastern Puente Hills, Los Angeles basin, California: U.S. Geol. Survey Oil and Gas Inv. Map OM-195, scale $1: 24,000$.

Geology of the eastern half of the Puente Hills. Reintroduces the name Fernando for Pliocene strata of the Puente Hills area and redefines the continental upper Pleistocene La Habra Formation.

1959. Poland, J. F., Garrett, A. A., and Sinnott, Allen, Geology, hydrology, and chemical character of ground waters in the Torrance-Santa Monica area, California: U.S. Geol. Survey Water-Supply Paper 1461, $425 \mathrm{p}$.

Includes a map (scale $1: 31,680$ ) of the surface geology of the coastal area between the Palos Verdes Hills and the Santa Monica Mountains and describes the water-bearing strata.

1960. Emery, K. O., The sea off southern California; a modern habitat of petroleum: New York, John Wiley \& Sons, $366 \mathrm{p}$.

A comprehensive treatise on the geology and physiography of the area between the mainland coast and the continental slope of southern California. Synthesizes the essential elements from a mass of published and previously unpublished material and implies a comparable development of the Los Angeles basin. Includes a comprehensive bibliography.

1960. McCulloh, T. H., Gravity variations and the geology of the Los Angeles basin of California, in Short papers in the geological sciences: U.S. Geol. Survey Prof. Paper 400-B, p. B320-B325.

A summary of a study based on surface and known subsurface geology of the entire basin area and its margins, and measured gravity variations.

1960. Woodford, A. O., Bedrock patterns and strike-slip faulting in southwestern California: Am. Jour. Șci., v. 258-A (Bradley volume), p. 400-417.

The pre-Turonian rocks of southwestern California are mapped in eight units, which are described and compared. 
1961. Silberling, N. J., Schoellhamer, J. E., Gray, C. H., Jr., and Imlay, R. W., Upper Jurassic fossils from the Bedford Canyon Formation, southern California: Am. Assoc. Petroleum Geologists Bull., v. 45, no. 10, p. 1746-1748.

Previous Triassic determination for the Bedford Canyon Formation is modified and new findings are described. A Late Jurassic age also is indicated by fossils from the Santa Monica Slate.

1961. California Department of Water Resources, Ground water geology, Appendix A of Planned utilization of the ground water basins of the coastal plain of Los Angeles County: California Dept. Water Resources Bull. 104, 181 p.

Geology and geologic history of the Pleistocene and Recent strata in the Los Angeles County part of the central lowland plain and southwest coastal area. Includes colored geologic maps, scale 1 inch to 2 miles, and sections, scale 1 inch to 450 feet vertical and 1 inch to 4,500 feet horizontal.
1962. Knapp, R. R., chm., and others, Cenozoic correlation section across Los Angeles basin from Beverly Hills to Newport, California: Am. Assoc. Petroleum Geologists, Pacific Sec., scale 1 inch to 1,000 feet vertical and 1 inch to 5,000 feet horizontal.

A stratigraphic and structural correlation section based on data from drilling in 13 oil fields along the Newport-Inglewood zone.

\section{REGIONAL SETTING OF THE BASIN}

Coastal southern California includes parts of three geomorphic provinces: the Coast Ranges, north of lat $34^{\circ} 30^{\prime} \mathrm{N}$.; the Transverse Ranges, between lat $34^{\circ} \mathrm{N}$. and lat $34^{\circ} 30^{\prime} \mathrm{N}$; ; and the Peninsular Ranges, south of lat $34^{\circ} \mathrm{N}$. (fig. 4 ). The western parts of all three provinces are submerged under the Pacific Ocean. The Coast Ranges province, which extends north from the Transverse Ranges province into central California,

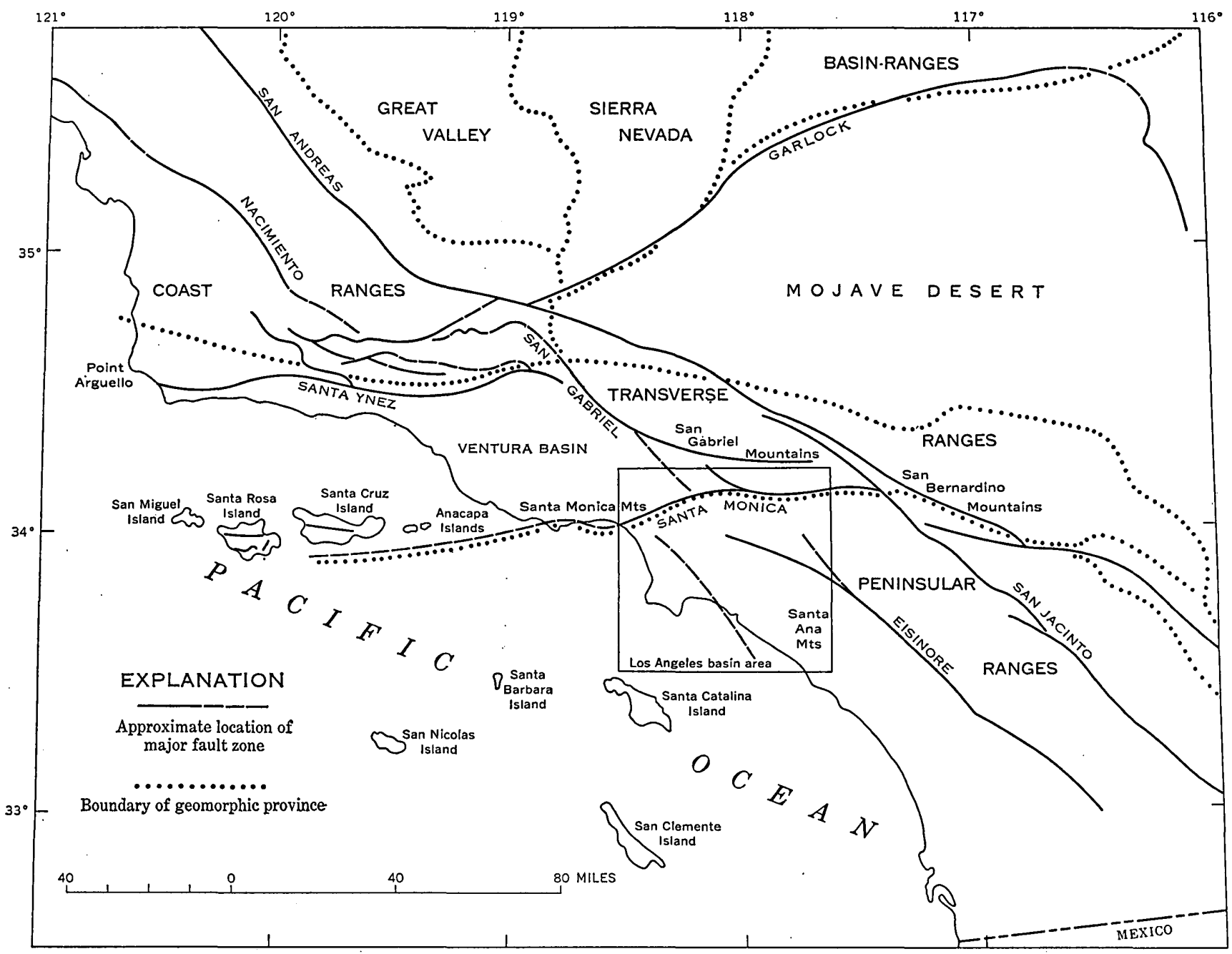

Fraure 4.- Outline map of southern California showing Los Angeles basin area, major fạult zones, and boundaries of geomorphic provinces. Modified from O. P. Jenkins $(1938 \mathrm{a}, \mathrm{b})$. 
and the Peninsular Ranges province, which extends south into Baja California, have conspicuous northwest trends. They are transected by the east-trending ridges and valleys of the Transverse Ranges province.

The present-day Los Angeles basin is at the north end of the Peninsular Ranges province. The physiographic basin is bounded on the east and southeast by the Santa Ana Mountains and San Joaquin Hills; on the northwest, it is bounded by the Santa Monica Mountains of the Transverse Ranges province, and the province boundary is an east-trending zone of faults.

\section{PENINSULAR RANGES PROVINCE}

The backbone of the Peninsular Ranges province, an elongate series of mountainous ridges and peaks rising in places to altitudes of more than 10,000 feet, extends southeastward about 900 miles from near lat $34^{\circ} \mathrm{N}$. in the vicinity of the Los Angeles basin to the tip of Baja California. The largest part of the province is submerged. This part is termed the "continental borderland" by Shepard and Emery (1941) to distinguish it from the continental slope farther seaward. Both the submerged and exposed parts of the province are characterized by elongate northwesttrending mountain ridges separated by straight-sided sediment-floored valleys. Many of the mountainous tracts on land are characterized by extensive areas of subdued topography. Some of the alluviated land valleys are undrained depressions occupied by lakes and dry sinks. Comparable topography exists on the continental borderland; elongate ridges rise thousands of feet above the sea floor to form submarine ranges whose peaks in a few places are islands or banks. Between such submarine ranges are elongate deep basins, most of them closed or silled depressions, in which water depths range from 2,800 to 7,000 feet.

The exposed part of the province is 55 to 80 miles wide; it has been uplifted, tilted seaward, and sliced longitudinally into subparallel blocks by young steeply dipping northwest-trending fault zones. The submerged part of the province is a much wider area, but it is similar except that it has lower relief. (See Jahns, 1954, p. 29-52, for a generalized geologic map and description of the exposed part of the province and Emery, 1960, for a comprehensive description of the continental borderland.)

The geology of the continental borderland is known only from exposures on Santa Barbara, Santa Catalina, San Clemente, and San Nicolas Islands, supplemented by geophysical data and scattered sea-floor samples (Emery, 1960, p. 62-96).
In both the exposed and submerged parts of the province, basement rocks are overlain by marine and nonmarine clastic strata of Late Cretaceous or Cenozoic age. A belt of clastic strata is present along the southern California coast from San Diego to Los Angeles. The width of the belt increases severalfold in the area of the Los Angeles basin and the strata thicken abruptly to a maximum of about 32,000 feet beneath the center of the basin (pl. 2). In the offshore part of the province, known outcrops of basement rocks are confined to a few banks and Santa Catalina Island, and superjacent strata are much more extensive than on land. Superjacent rocks on the islands and banks are mostly middle Miocene or older Tertiary in age (Emery, 1960, p. 67; Vedder and Norris, 1963). The basins are floored by younger Cenozoic strata and are sites of active sedimentation.

The dominant structural features of the Peninsular Ranges province are northwest- to west-northwesttrending fault zones; these zones separate large elongate blocks that stand at different structural elevations. Most of the faults either die out to the northwest or merge with or are terminated by the easttrending steep reverse faults that form the southern margin of the Transverse Ranges province. In the northern part of the province the major faults appear to be late Cenozoic in age, and many are seismically active. Large folds are few in the exposed part of the province; these have west- to northwest-trending axes.

\section{TRANSVERSE RANGES PROVINCE}

The exposed part of the Transverse Ranges province extends about 275 miles eastward from Point Árguello into the Mojave Desert and is as much as 50 miles wide (fig. 4). The submerged part projects westward beyond Point Arguello and San Miguel Island and may merge with the Murray fracture zone (Menard, 1955), a major structural feature of the northeast Pacific Ocean. Anacapa, Santa Cruz, Santa Rosa, and San Miguel Islands (fig. 4) form the seaward extension of the southwesternmost range of the province. Both the southern and northern boundaries of the western part of the province are fault scarps or fault-line scarps situated along important east-trending transcurrent faults, the Santa Monica and Santa Ynez fault zones.

Most of the province is mountainous; many of the higher ridges and peaks rise above 5,000 feet, and the highest mountains rise more than 10,000 feet above sea level. The backbone of the province, in its central and eastern parts, is formed by the San Gabriel and San Bernardino Mountains. These mountains are un- 
derlain largely by suites of pre-Tertiary metamorphic and plutonic igneous rocks. To the west these basement rocks plunge beneath a thick cover of Upper Cretaceous and Cenozoic sedimentary rocks; basement rocks are also exposed in the eastern Santa Monica Mountains and on Santa Cruz Island. The west part of the province is divided into mountainous belts on the north and south; these belts are separated by a topographic and structural depression, the Ventura basin and its seaward extension. About 58,000 feet of Upper Cretaceous and Cenozoic marine and nonmarine sedimentary rocks are present in the axial part of this depression (Bailey and Jahns, 1954, p. 95).

The geologic history of the eastern Santa Monica Mountains, Verdugo Mountains, and southern San Gabriel Mountains is intimately related to that of the Los Angeles basin; these areas are therefore included in the discussion of the Los Angeles basin. A generalized geologic map and a description of the exposed part of the province west of long $116^{\circ} 30^{\prime} \mathrm{W}$. have been published by Bailey and Jahns (1954, p. 83-106).

The topographically and structurally high San Gabriel Mountains are an east-trending lens-shaped mass about 80 miles long and as much as 27 miles wide. They are bounded on the northeast by the San Andreas fault zone and on the southwest by faults of the Sierra Madre-Cucamonga zone (fig. 3); they are cut internally by the San Gabriel fault zone and other faults (fig. 4). The extremely varied suite of basement rocks that comprises the mountains includes: the oldest known rocks of the region-gneisses, migmatites, anorthosites, and gabbroic rocks of Precambrian age (Silver and others, 1963) ; undated green schists, marbles, and quartzites; mylonites and charnockitic rocks; and plutonic intrusive rocks of Mesozoic age. Varied and distinctive detritus derived from these sources appears in the superjacent sedimentary strata of the Los Angeles basin and is a useful indicator of source and direction of sediment transport.

\section{GEOGRAPHIC AND GEOLOGIC ELEMENTS OF THE BASIN}

Contrasting or partly contrasting rocks occur in four large subdivisions of the Los Angeles basin (pls. 1, 2, and 3). Each subdivision is a structural block whose contacts with adjoining blocks are major zones of faulting or flexure in the basement rocks (figs. 2 and 3) along which vertical and lateral movement took place intermittently during deposition of the superjacent rocks. Because of the contrasts, the stratigraphy of the basin is described in terms of these blocks, which are informally designated the south- western, northwestern, central, and northeastern blocks.

The distribution, thickness, and structure of the rocks in different parts of the basin are based on regional subsurface studies, exposed sections, scattered wells drilled for oil, and geophysical data and are illustrated in the panel diagram (pl. 3) and the structure sections (pl. 4).

\section{SOUTHWESTERN BLOCK}

The southwestern block of the Los Angeles basin is the exposed part of a much larger tract, most of which is beneath the Pacific Ocean (fig. 3). It is roughly rectangular and is about 28 miles long from northwest to southeast and 5 to 12 miles wide. Most of it is a low plain which extends from Santa Monica at the northwest to Long Beach at the southeast. The Palos Verdes Hills, which rise to an altitude of about 1,300 feet at the southwest extremity of the plain, are the most prominent topographic feature of the block; a line of elongated low hills and mesas (underlain by the Newport-Inglewood zone of deformation) extends from northwest to southeast along the inland margin of the plain.

The basement rocks of the southwestern block are exposed in only one small area on the north slope of the Palos Verdes Hills, but these rocks have been found in many oil wells drilled throughout the low plain between the hills and the Newport-Inglewood zone (fig. 5). The basement surface is more than 1,000 feet above sea level where it is exposed on the north slope of the Palos Verdes Hills, but beneath the coastal plain to the north it is between 5,000 and 14,000 feet below sea level and generally slopes northeast (fig. 2).

The superjacent rocks of the southwestern block are about 20,500 feet thick and are chiefly marine sedimentary strata of middle Miocene to Recent age; locally they include igneous rocks of middle Miocene age.

The major structural elements of the southwestern block include the northwest-trending, doubly plunging anticline that underlies the Palos Verdes Hills, the steeply southwest-dipping Palos Verdes Hills fault zone on which the hills are upthrown along their northeast margin, and the buried'northwest-trending anticlinal arches in the basement surface that underlies the low plain north of the hills (fig. 2).

\section{NORTHWESTERN BLOCK}

The northwestern block includes parts of the easttrending Santa Monica Mountains, the Verdugo Mountains, and the San Fernando Valley. The Santa 
Monica Mountains are about 45 miles long, but only the easternmost 15 miles adjoin the other blocks of the Los Angeles basin. This part of the range is about 8 miles wide at the west and tapers to about 2 miles at the east. The crest of the range rises from less than 1,000 feet above sea level at the east to about 2,000 feet near long $118^{\circ} 30^{\prime} \mathrm{W}$.

The basement rocks of the northwestern block are exposed in the eastern Santa Monica and Verdugo Mountains and locally in intervening areas (fig. 5). The superjacent rocks are about 14,500 feet thick in the east part of the Santa Monica Mountains and consist of marine clastic sedimentary strata of Late Cretaceous to Pleistocene age and of middle Miocene volcanic rocks.

The eastern Santa Monica Mountains are formed by a broad west-plunging anticline, which is transected by a northeast-trending branch of the Santa Monica fault zone. The south flank of the anticline is truncated by the Santa Monica fault zone, along which it is upthrown; the north flank dips northward into the San Fernando Valley.

\section{CentraL BLOCK}

The central block is wedge shaped in plan; it is about 55 miles long from the Santa Monica Mountains at the northwest to and including the San Joaquin Hills at the southeast, and it widens from about 10 miles at the northwest to more than 20 miles at the southeast. Physiographic features of the block include: the aggraded central lowland plain; the low Elysian Hills at the northwest end; parts of the Repetto Hills; the elongated east-trending Coyote Hills; the shallow synclinal La Habra Valley along the northeast margin; the prominent Santa Ana Mountains, which rise to an altitude of 5,700 feet, at the east margin; and the low San Joaquin Hills at the southeast margin. The southwest margin of the central plain is the northwest-trending line of low hills and mesas (underlain by the Newport-Inglewood zone of deformation) that extends from the mouth of the Santa Ana River to Beverly Hills.

The basement rocks of the central block are exposed only in the core of the Santa Ana Mountains (fig. 5).

The superjacent rocks of the central block are best exposed on the west slopes of the Santa Ana Mountains where they attain a maximum thickness of at least 32,000 feet. They consist of marine and nonmarine clastic sedimentary rocks of Late Cretaceous through Pleistocene age and interbedded volcanic rocks of middle Miocene age. It is inferred from regional stratigraphic studies that, in the central part of the block, the lower parts of this succession are thinned or missing beneath younger rocks; the Pliocene and Quaternary strata are as much as four times as thick as in the Santa Ana Mountains; and the entire superjacent succession is at least 32,000 feet thick (see cols. 6 and 11, pl. 2, and pl. 3), but it may be as much as 35,000 feet thick.

The dominant structural feature of the central block is the northwest-trending, doubly plunging synclinal trough underlying its central part (figs. 2 and 3 ). The basement surface in the axial part of this trough plunges from depths of 13,000 to 16,000 feet below sea level at its distal ends to depths of at least 31,000 feet subsea in its central part. The southwest flank of the synclinal trough rises steeply to a subsea depth of about 14,000 feet along the Newport-Inglewood zone, but its northeast flank rises gently, then abruptly, to merge with a broad, gently sloping shelf that has an average depth of about 15,000 feet subsea and that is complicated by several subsidiary folds and faults.

\section{NORTHEASTERN BLOCK}

The northeastern block of the Los Angeles basin is a triangular wedge about 35 miles long from northwest to southeast; from its narrow west end it widens to about 18 miles at long $117^{\circ} 371 /^{\prime}$ W. The low Repetto Hills and the Puente Hills, which rise to altitudes of 1,000 to 1,800 feet, form an arc along the south part of the block and are separated by the Whittier Narrows, a gap through which the Rio Hondo and San Gabriel River flow. Northwest of the Puente Hills is the alluviated San Gabriel Valley, an almost closed basin that is drained by the two rivers. East of the San Gabriel Valley are the elongate northeast-trending low San Jose Hills.

The basement rocks of the northeastern block are exposed at the north end of the Puente and San Jose Hills. The superjacent rocks are as much as 24,000 feet thick and consist chiefly of fine- to coarse-grained marine clastic sedimentary rocks of Cenozoic age. In the east part of the block they locally include more than 4,000 feet of middle Miocene volcanic rocks as well as nonmarine sedimentary rocks of late Eocene (?) to early Miocene age. In the central Puente Hills the superjacent rocks include the greatest known thickness of upper Miocene strata in the Los Angeles basin-about 13,400 feet-and in the San Gabriel Valley they include about 6,000 feet of marine and nonmarine sedimentary rocks of Quaternary age.

The configuration of the basement surface is reflected in the topography of the block. Beneath the San Gabriel Valley, a closed elliptical depression on the basement surface attains a subsea depth of about 12,000 feet (figs. 2 and 3). The low hills southwest of 
the valley are underlain by the east-plunging Elysian Park anticline, which rises to subsea depths of 1,000 to 4,000 feet. Beneath the Puente Hills southeast of the valley is a roughly triangular area that has a general southwest slope from sea level at the north to 8,000 feet subsea at the south; this area is complicated by subsidiary ridges, depressions, and faults. The San Jose Hills east of the valley are underlain by an elongated southwest-plunging anticline. The Chino basin is underlain by a narrow south-plunging depression at subsea depths of 2,000 to 8,000 feet. The basement surface of the block is cut by northwest- to northeast-trending faults that break through the superjacent rocks to the surface.

\section{EVOLUTION OF THE BASIN}

The most distinctive geologic characteristic of the Los Angeles basin is its structural relief and complexity in relation to its age and size. For example, the basement surface has a relief of about 4.5 miles between the central deep part of the basin and the Whittier Narrows 8 miles to the northeast (fig. 2). Almost 3 miles of this relief is due to continuous subsidence and deposition in late Miocene and Pliocene time. The marked differences in rate and amount of subsidence caused pronounced lateral variations in lithology and thickness in most of the sedimentary rock units; contemporaneous folding and faulting, accompanied by local erosion, resulted in numerous regional and local unconformities, disconformities, and stratigraphic discontinuities across faults. The geologic history of the basin has five major phases, each of which is represented by a distinctive assemblage of rocks.

\section{PREDEPOSITIONAL PHASE-ROCKS OF THE BASE- MENT COMPLEX}

The floor of the basin upon which the superjacent rocks accumulated is a heterogeneous assemblage of thermally and dynamothermally metamorphosed sedimentary and volcanic rocks, in part intruded by plutonic rocks. These basement rocks are pre-Late Cretaceous (pre-Turonian) in age and are divided into two physically separate and genetically distinct groups, the eastern basement complex of the northwestern, central, and northeasterm blocks, and the western basement complex of the southwestern block.

Pre-middle Miocene spatial relations of the eastern and western basement complexes cannot be ascertained, in part because pre-middle Miocene strata are missing in the southwestern block (pl. 4 and figs. 8 and 9). Because detritus from the distinctive western basement rocks is absent in strata older than middle
Miocene, because the western basement is unconformably overlain by middle Miocene strata, and because these basement rocks are not known to be intruded by Upper Cretaceous plutonic rocks, it is inferred that the eastern and western basement complexes were juxtaposed along the Newport-Inglewood zone by large-scale movement during some interval between early Late Cretaceous and early middle Miocene time. Juxtaposition of the two complexes along the Santa Monica fault zone occurred before late Pliocene time.

\section{PREBASIN PHASE OF DEPOSITION-UPPER CRE- TACEOUS TO LOWER MIOCENE ROCKS}

The Upper Cretaceous to lower Miocene rocks include as much as 5,900 feet of chiefly marine clastic sedimentary deposits of Late Cretaceous age and as much as 11,000 feet of shallow-water marine and nonmarine clastic sedimentary deposits of Paleocene to early Miocene age. These rocks are unmetamorphosed, are known to be present only in areas underlain by eastern basement, and are prebasin strata that were evidently deposited over a broad area in a shallow marine or nonmarine environment during three cycles of marine transgression and regression (figs. 6, 7, 8, and 13).

The geographic extent of the embayments and flood plains that received the sediments is largely masked. The original north-central and northeast limits of deposition probably did not extend far beyond the present limits shown for the upper Eocene(?) to lower Miocene rocks (fig. 8); the northwest and southwest limits cannot be ascertained, but they were probably outside the basin area. The southwestern block is not known to contain pre-middle Miocene sedimentary rocks; whether their absence is due to nondeposition or erosion is conjectural. The relative geographic position of this block may have changed as a result of faulting during the prebasin phase. However, the presence of almost 14,000 feet of pre-middle Miocene strata in the San Joaquin Hills just northeast of the Newport-Inglewood zone sugggests that these strata must once have extended southwestward across the present site of the fault zone.

The source of most of the Upper Cretaceous and lower Tertiary sediments was north, northeast, or east of the area of deposition in a rising region of moderate relief that was underlain by slightly to deeply weathered igneous and metamorphic eastern basement rocks. The broad and relatively shallow area of deposition only roughly foreshadowed the size and shape of the deep constricted basin that was to form later in Tertiary time. 


\section{BASIN-INCEPTION PHASE-MIDDLE MIOCENE} ROCKS

The deposition of the locally thick Upper Cretaceous and lower Tertiary rocks was followed by a significant episode of emergence and erosion, as indicated by the almost basinwide unconformity at the base of the middle Miocene (pl. 1). Emergence varied considerably in duration and degree from one part of the basin to another. It probably occurred at different times in different parts of the basin and may not have occurred at all in the southeast part of the central block. The base of the middle Miocene succession thus commonly has transgressive overlap relations, and, in large parts of the southwestern and northeastern blocks, middle Miocene strata rest directly upon basement rocks. The middle Miocene is a varied and widespread succession of marine clastic sedimentary rocks, less extensive fine-grained siliceous organic sedimentary rocks, and interbedded, basic to intermediate volcanic rocks. This succession attains thicknesses of about 10,000 feet in both the Santa Monica Mountains and the San Joaquin Hills.

During much of middle Miocene time a northwesttrending marine embayment covered the site of the Los Angeles basin. The embayment was bordered on the northeast and southwest by elevated tracts of contrasting basement rocks. The northeast edge of the embayment coincided very nearly with the present inland boundary (fig. 9), and the north edge was not far north of the Sierra Madre-Cucamonga fault zone. Rivers that drained the highlands north and east of the shoreline transported great volumes of eastern basement detritus to the northeast edge of the embayment; the detritus forms thick bodies of poorly sorted argosic sandstone and sandy cobble-boulder conglomerate in the northern Santa Ana Mountains, the Puente and San Jose Hills, the south margin of the San Gabriel Mountains, and the eastern Santa Monica Mountains. These rocks characteristically grade and interfinger southwestward, locally with amazing abruptness, into thin-bedded relatively well-sorted marine siltstone and shale.

The southwest shoreline of the middle Miocene embayment was probably not more than a few miles southwest of the present coastline, but it cannot be precisely located. An extensive tract of western basement rocks (now largely buried and submerged offshore) was elevated in middle Miocene time to form an island or peninsula between the open sea and the embayment of the basin area. Large quantities of coarse angular schist debris were transported, probably by landslides or debris flows, from the northeast margin of this landmass and dumped along the southwest edge of the embayment. These deposits are exposed as thick bodies, lenses, and beds of schist breccia in the San Joaquin Hills and Palos Verdes Hills, and they have been found in wells drilled in the Sunset Beach, Huntington Beach, and West Newport oil fields. In the San Joaquin Hills the breccias interfinger northeastward with fine-grained, dominantly siliceous organic sedimentary rocks.

The greatest thickness of middle Miocene rocks accumulated in the northwest and southeast parts of the embayment, areas now occupied by the Santa Monica Mountains and the San Joaquin Hills. Other thick accumulations are present along the northeast margin of the embayment (now the Puente and San Jose Hills) and in its axial part, which coincided approximately with the synclinal trough of the present-day basin. In late middle Miocene time, several centers of volcanic activity-one in the east part of the northeastern block, one in the northwestern block, and one probably in the southeast part of the central blockextruded great volumes of lava, much of it as submarine flows and fragmental rocks of chiefly basic to intermediate calcic composition. The volcanic episode corresponded in a general way to a period of tectonic unrest that was also manifested by increased rates of subsidence and local deformation. The area underlain by the volcanic rocks (fig. 9) corresponds roughly to the area that subsided most rapidly; numerous faults and unconformities within the succession and rapid changes in facies and thickness attest to the tectonic unrest.

Following deposition of the middle Miocene, the sea withdrew from parts of the embayment and exposed extensive areas to erosion. As a consequence, middle Miocene rocks were stripped from areas of the northwestern and southwestern blocks, from the Elysian Park anticline area in the northeastern block, from the Anaheim nose and its southeastward extension in the central block, and from the horst beneath the Long Beach oil field. Locally, however, as in the Palos Verdes and San Joaquin Hills and, perhaps, in the deep part of the central block, deposition continued into late Miocene time nearly without interruption.

PRINCIPAI PHASE OF SUBSIDENCE AND DEPOSITION-UPPER MIOCENE TO LOWER PLEISTOCENE ROCKS

The present form and structural relief of the Los. Angeles basin was largely established during the phase of accelerated subsidence and deposition that began in late Miocene time and continued without significant interruption through early Pleistocene time. The embayment that resulted from the renewed subsidence covered most of the area of the middle 
Miocene embayment, and by the end of Miocene time its encroachment attained a maximum for the Cenozoic. Clastic sedimentary rocks, chiefly feldspathic sandstone, micaceous siltstone, and lesser amounts of polymictic conglomerate, shale, and fine-grained siliceous biogenic sediment, accumulated rapidly in a submarine depression in which the water was about 3,000 feet deep at the end of Miocene time. The clastic sediment was derived from highland areas to the north, northeast, and east of the embayment; it moved down the submarine slopes along its north and east margins, and spread southward and westward across the basin floor. The upper Miocene sedimentary units thin southwestward across the basin, and their grain size and total sand content decrease southwestward. Large quantities of organic matter contained in the finer grained sediment formed the source of large volumes of oil.

Not all parts of the basin were submerged simultaneously nor were the rates of sedimentation everywhere equal; subsidence and sedimentation probably began in the south part of the basin near the stillsubmerged San Joaquin Hills area and from there spread both north and west. In this manner the large tract of western basement that was exposed north of the Palos Verdes Hills fault zone by post-middle Miocene emergence was transgressively overlapped from northeast to southwest by upper Miocene deposits derived from eastern basement rocks. These deposits also thin and pinch out against the flanks of the Anaheim nose in the east-central part of the central block (section E-F, pl. 4; and fig. 10) and thin from every direction against the Inglewood anticline on the northwest boundary of the block. In the northeastern block, upper Miocene strata were deposited on older and older rocks as they transgressed from south to north. At the close of the Miocene the most extensive embayment of Cenozoic time occupied the basin area; its north margin was bordered by hills that would later become the San Gabriel Mountains, and its surface was interrupted only by a shoal or island at the site of the present-day Anaheim nose.

Over much of the basin, subsidence and deposition continued without interruption from late Miocene into Pliocene time (fig. 11). In the central block and adjoining parts of the southwestern and northeastern blocks, the sea bottom attained its maximum rate of subsidence (fig. 13), and, because deposition did not keep pace with subsidence, water depth in the central parts of the basin attained a maximum of about 6,000 feet late in early Pliocene time. However, while the central part of the basin sank, its margins rose, and the area of deposition shrank. Near the beginning of
Pliocene time, the Palos Verdes Hills area of the southwestern block was uplifted for the first time since early in the middle Miocene. A hiatus was thus produced between deep-water upper Miocene mudstone and an extremely attenuated deep-water lower Pliocene siltstone; this section is about 150 feet thick, whereas equivalent strata just northeast of the Palos Verdes Hills fault zone are about 1,800 feet thick-a circumstance that may be due to lateral movement on the fault zone in Quaternary time. The Santa Monica Mountains in the northwestern block, which were stripped of much of their sedimentary cover at the end of middle Miocene time and were covered again by a thick unconformable blanket of upper Miocene strata, were uplifted in early Pliocene time along the Santa Monica fault zone and have not since been submerged. Erosional unconformities near the base of the Pliocene rocks in the Inglewood and Huntington Beach oil fields, near Newport Bay, in the Santa Ana Mountains, in the Coyote Hills, and in the Anaheim nose area attest to the tectonic unrest of the basin margins during the interval of most rapid subsidence in the central part of the basin.

During early Pliocene time, great volumes of clastic material, which consisted largely of silt and sand but which included clay and gravel as well, entered the basin along its north and northeast margins. The material was transported across the north slopes of the basin, perhaps by submarine turbid flows, to be trapped in the rapidly subsiding parts of the basin. A gradual increase in grain size or percentage of sand from base to top of the lower Pliocene sequence in the central part of the basin suggests a gradual increase of topographic relief in the source areas. The thickness variations of the sequence (fig. 12) were evidently controlled largely by subsidence of the basin floor.

Subsidence and deposition continued in the central part of the basin without interruption into late Pliocene time, but the rate of deposition gradually overtook the rate of subsidence, and the depth of water began to decrease (fig. 13). In the marginal areas of the basin, tectonic activity continued. Unconformities within the upper Pliocene sequence or at its base indicate increasing tectonic unrest in such areas as the Palos Verdes Hills, the Torrance and Wilmington oil fields, the southeast half of the Newport-Inglewood zone, the San Joaquin Hills, the northern Santa Ana Mountains, the Coyote Hills and Anaheim nose, the southwest margin of the Puente Hills, the Los Angeles City area, and the Santa Monica fault zone. Uplift and erosion of the southwest margin of the northeastern block, due to activity along the Whittier fault zone, are indicated by detritus of upper Miocene 
rocks, derived from the Puente Hills, in upper Pliocene strata now exposed just south of the fault zone. Conversely, within the northeastern block, the great increase in thickness of the upper Pliocene sequence from the Puente and San Jose Hills toward the San Gabriel Valley, which had probably been an area of limited and gradual subsidence since middle Miocene time, indicates that in late Pliocene time the area began to subside very rapidly to become a trap for thousands of feet of coarse-grained upper Pliocene and Pleistocene strata.

Most of the sediment deposited during early Pliocene time was derived chiefly from areas north of the basin, and only minor amounts were contributed by locally emergent areas such as the Palos Verdes Hills and the islands of the Torrance-Wilmington oil field area. In contrast, in late Pliocene time the rising southwest margin of the Puente Hills shed significant amounts of detritus into the sea, but the Santa Monica Mountains were evidently not high enough to contribute important volumes of distinctive sediment. Shallow-water or littoral sediments are prevalent in exposures of the upper Pliocene around the margins of the basin, and Foraminifera from the sequence in the subsurface of the central block indicate that the sea bottom there shoaled from a depth of about 4,000 feet early in the late Pliocene to about 900 feet at the end of the Pliocene (fig. 13). The character of the upper Pliocene deposits reflects increasing topographic relief of the source areas. Sandstone constitutes more than half the total volume, and siltstone makes up most of the balance; conglomerate and pebbly sandstone are much more prevalent than shale, and other rock types are extremely rare.

Although the basin of deposition was still very large at the end of the Pliocene, many marginal areas stood above sea level. The Palos Verdes Hills formed an island, and large parts of the Santa Monica Mountains and San Gabriel Mountains, the Puente Hills, the Santa Ana Mountains, and extensive areas along the Newport-Inglewood zone and parts of the southwestern block were exposed or were above wave base.

Very early in the Pleistocene the Palos Verdes Hills and the southwestern block subsided and marine deposition resumed in those areas. The central block, parts of which had subsided and been filled by more than 18,000 feet of sediments since the end of middle Miocene time, continued to subside and fill; the San Joaquin Hills remained submerged as did the central block, whereas the Santa Ana Mountains remained emergent. The San Gabriel Valley, which had just become a distinct and separate structural entity, con- tinued its rapid subsidence, whereas adjoining parts of the northeastern block such as the Puente and Repetto Hills continued to rise. The San Gabriel Mountains were elevated to ever greater heights by uplift along the Sierra Madre-Cucamonga fault zone, and the streams that drained these mountains transported loads of ever coarser debris of igneous and metamorphic rocks to the margin of the basin. The Santa Monica Mountains remained emergent but were probably quite subdued.

During early Pleistocene time, rapid deposition in depressed parts of the basin exceeded subsidence, and the shoreline gradually receded southwestward from the San Gabriel Valley; many hundreds of feet of sand and gravel accumulated in the valley, and as much as 1,800 feet of fine-grained sand and silt was deposited in the central block in an environment of open water of moderate depth. The southwestern block northeast of the Palos Verdes Hills fault zone received as much as 1,000 feet of marine sand and gravel that was deposited in water of moderate depth; parts of the Palos Verdes Hills received as much as 600 feet of marine marl, silt, and sand that was deposited in water as deep as 600 feet.

At the end of early Pleistocene time the shoreline in inland parts of the basin was approximately coincident with the present-day subsurface boundary of the upper Pliocene'sequence (fig. 14); the Santa Monica Mountains, the Elysian, Repetto, San Jose, and Puente Hills, and the Santa Ana Mountains stood in subdued relief above a low coastal plain that merged northeastward with coalescing alluvial fans extending from the San Gabriel Mountains. A chain of shoals or banks probably stood offshore along the NewportInglewood zone where anticlines were growing from the ocean floor in the Inglewood, Long Beach, and Huntington Beach oil field areas. An island or bank may also have existed over the anticline of the Palos Verdes Hills area.

\section{BASIN-DISRUPTION PHASE-UPPER PLEISTOCENE TO RECENT STRATA}

The central part of the basin continued to subside and to receive sediment throughout late Pleistocene and Recent time; floods of coarse clastic debris derived from the distant San Gabriel Mountains and the rapidly rising Puente Hills, Santa Ana Mountains, and eastern Santa Monica Mountains pushed the retreating shoreline southward and westward. Interfingering lagoonal marine and nonmarine deposits of late Pleistocene age may attain a maximum thickness of about 2,500 feet in the central part of the basin, where they are probably conformable on marine lower 
Pleistocene strata and are overlain by not more than 200 feet of Recent nonmarine gravel, sand; and silt.

The middle to late Pleistocene history of the Palos Verdes Hills contrasts markedly with that of the central part of the basin. At the end of early Pleistocene time most of the southwestern block was slightly below sea level and was blanketed by 300 to 1,000 feet of marine lower Pleistocene strata. Renewed deformation of the Palos Verdes Hills anticline then occurred by downfolding of the flanks and subsidence of the surrounding areas. The folded Pleistocene strata then broke along the Palos Verdes Hills fault zone, and the hills rose, in a series of steps that were separated by periods of stillstand, relative to sea level and to the rest of the southwestern block. Thirteen recognized platforms were cut around the periphery of the island during the periods of stillstand; the highest and oldest of these terraces has an altitude of about 1,300 feet; the lowest and youngest, which has an age of more than 30,000 years, has an altitude of about 100 feet. Marine sand and gravel preserved on nine of the platforms, particularly on the lowest, 100foot terrace, contain fossil mollusks that have been correlated with those from the marine deposits that conformably overlie lower Pleistocene strata on the lowland part of the southwestern block. Along the northwest margin of the hills, deposits on the lowest platform have been folded along the Palos Verdes Hills fault zone; locally they $\operatorname{dip} 26^{\circ}$.

After cutting of the lowest terrace platform on the Palos Verdes Hills and deposition of upper Pleistocene strata elsewhere on the southwestern and central blocks, successive relative lowerings of sea level caused rivers that flowed across the constructional coastal plain to entrench themselves to depths as great as 250 feet near the present shoreline; these rivers cut gaps through the hills that were rising along the NewportInglewood zone, and they cut channels in the newly emerged upper Pleistocene sea bottom to distances of thousands of feet seaward of the present shoreline. Subsequent relative rise of sea level then caused renewed alluviation, and the channels were filled with Recent deposits, which extend inland through the gaps to merge with surficial deposits of the central part of the basin.

The structural features along the central part of the Newport-Inglewood zone did not have topographic expression before late Pleistocene time. After the emergence of these features from the sea, continued growth of anticlines along the zone resulted in radial consequent drainage on the oval hill over the faulted Dominguez anticline and caused antecedent breaching of the elongate domal hill over the Seal Beach anti- cline. Continued deformation along the zone produced fault scarps in the alluvial surface such as those exposed at Baldwin Hills and in the area between Signal Hill and Huntington Beach Mesa.

After deposition of lower Pleistocene strata along the south margin of the eastern Santa Monica Mountains, the mountains were arched along a west-trending axis; the arching was accompanied by dip-slip uplift on the Santa Monica-Raymond Hill fault zone (Knapp and others, 1962). Marine upper Pliocene and Pleistocene deposits north and west of Santa Monica were elevated many hundreds of feet above sea level. Deformation along the Sierra Madre-Cucamonga fault zone has continued into Recent time and has caused formation of scarps in unweathered alluvium and tilting of poorly consolidated nonmarine deposits of late Pliocene or Pleistocene age. Although the Whittier fault zone may have moved as early as Miocene time and was almost certainly the site of vertical movements in Pliocene time, oblique slip of large magnitude followed deposition of nonmarine upper Pleistocene beds along the south margin of the Puente Hills; these strata are in many places steeply tilted and locally overturned. Of an estimated 15,000 feet of oblique net slip that has accumulated since late Miocene time along the central part of the fault zone, about 5,500 feet of right-lateral strike slip resulted from Pleistocene and (or) Recent movements, during which present-day stream courses may have been offset.

The Coyote Hills uplift, which was probably initiated in late Miocene or early Pliocene time, was rejuvenated in latest Pleistocene time and probably continues to grow. Folding and lifting of the Santa Ana Mountains probably began in Pliocene time; but it continued, probably at an accelerating rate, in Pleistocene time.

The Quaternary history of the San Joaquin Hills is analogous to that of the Palos Verdes Hills. The hills were partly mantled by as much as 1,000 feet of marine sand during early Pleistocene time; this deposition was followed during late Pleistocene time by deformation, subsidence, and intermittent uplift relative to sea level. Eight recognizable terrace platforms were eroded into the seaward slopes of the hills between intervals of uplift; the highest platform now has an altitude of about 1,000 feet.

\section{STRATIGRAPHY OF THE BASIN}

The rocks of southwestern California, including those of the Los Angeles basin, are separated into two large groups by a pronounced unconformity of midCretaceous age. Below the unconformity are basement 
rocks, metamorphic and igneous crystalline rocks of Precambrian to early Late Cretaceous (Cenomanian?) age; above the unconformity is a thick succession of marine and nonmarine sedimentary and volcanic rocks of Late Cretaceous (Turonian) to Recent age, the superjacent rocks.

\section{BASEMENT ROCKS}

The basement rocks of the Los Angeles basin have been divided into western and eastern complexes by Woodford (1925) on the basis of their contrasting lithology and mineralogy. The western complex underlies only the southwestern block, whereas the eastern complex is known or inferred to underlie all other blocks of the basin (fig. 5).

\section{SOUTHWESTERN BLOCK}

The western basement rocks of the southwestern block have been assigned to the Catalina Schist (Schoellhamer and Woodford, 1951). The Catalina Schist is exposed on the mainland only in a small area on the north slope of the Palos Verdes Hills, where it is chiefly fine-grained chlorite-quartz schist and blue glaucophane- or crossite-bearing schist but includes less abundant chlorite-muscovite-albite-quartz schist, quartz-chlorite-tremolite-lawsonite(?) rock, quartzfree chlorite-talc(?) schist, and metagabbro.

Similar rocks have been found at the bottoms of more than 100 wells drilled in the lowland part of the southwestern block north of the hills (fig. 5). In addition to the rock types exposed in the hills, samples from the wells include glaucophane- or lawsonitebearing schist that also contains epidote or zoisite, actinolite-bearing schist, garnet-bearing muscovitechlorite-quartz schist, massive rocks that consist largely of carbonate or serpentine, and metavolcanic rocks. The distinctive minerals glaucophane and lawsonite are widespread, but are seldom abundant in samples of the schist. However, near the northeast margin of the block along the Newport-Inglewood zone, glaucophane and lawsonite schists are absent and exceptional types such as garnet-bearing schist, serpentinite, metagabbro, and metavolcanic rocks occur.

Neither the age nor the stratigraphic position of the Catalina Schist is known. In the southwestern block the oldest known superjacent rocks are middle Miocene, and nowhere has detritus from this distinctive schist basement been recognized in strata older than Miocene. The Catalina Schist of the mainland has been correlated with similar schist exposed on Santa Catalina Island 20 miles to the southwest (Woodford, 1924). That schist is associated with a thick section of slightly metamorphosed graywacke, shale, chert, conglomerate, metavolcanic rocks, and serpentine bodies. This section is intruded in the south part of the island by a large body of dacite porphyry and is overlain by extrusive andesitic and basaltic rocks of late(?) Miocene age.

Because of their unique lithologic features, the glaucophane-bearing rocks of southern California are correlated with those of the similar Franciscan Formation of coastal central California (Woodford, 1924, 1960). Like the Franciscan rocks of central California, the glaucophane-bearing rocks of southern California are bounded by faults, have no known base, and are nowhere intruded by plutonic rocks of the Southern California batholith. The Catalina Schist of the Los Angeles basin differs from the Franciscan in that it consists almost entirely of intensely foliated rocks, whereas on Santa Catalina: Island and in central California the rocks are chiefly graywacke and interbedded shale, conglomerate, chert, limestone, and volcanic rocks, locally metamorphosed and intruded by ultramafic rocks. Of these three sections, only the Franciscan of central California has yielded fossils; these fossils range in age from Late Jurassic to early Late Cretaceous (Irwin, 1957).

\section{NORTHWESTERN BLOCK}

The basement rocks of the northwestern block are assigned to the eastern complex and are exposed over large parts of the eastern Santa Monica Mountains and in the hills to the east (fig. 5). In the eastern Santa Monica Mountains the complex includes the Santa Monica Slate of Hoots (1931) and intrusive plutonic rocks. The Santa Monica Slate is intensely jointed dark-gray to black slate containing minor amounts of sheared metasiltstone and metasandstone, large tracts of which have been altered by contact metamorphism to mica schist, phyllite, and spotted cordierite slate. Hoots (1931) assigned a Triassic(?) age to the Santa Monica on the basis of lithologic correlation with similar rocks in the Santa Ana Mountains, then considered to be Triassic. However, pelecypod fragments recently discovered in the Santa Monica Slate and numerous fossils from the Bedford Canyon Formation indicate a Late Jurassic age for at least parts of both formations (Silberling and others, 1961; Imlay, 1963). The subsurface distribution of the Santa Monica Slate in the Northwestern block is not known; only one well, drilled through the Santa Monica fault zone from the Beverly Hills oil field, is known to bottom in slate of the northwestern block (fig. 5); Knapp and others, 1962).

Large areas of the eastern Santa Monica Mountains, as well as parts of the low hills and Verdugo Mountains to the east, are underlain by plutonic rocks of 


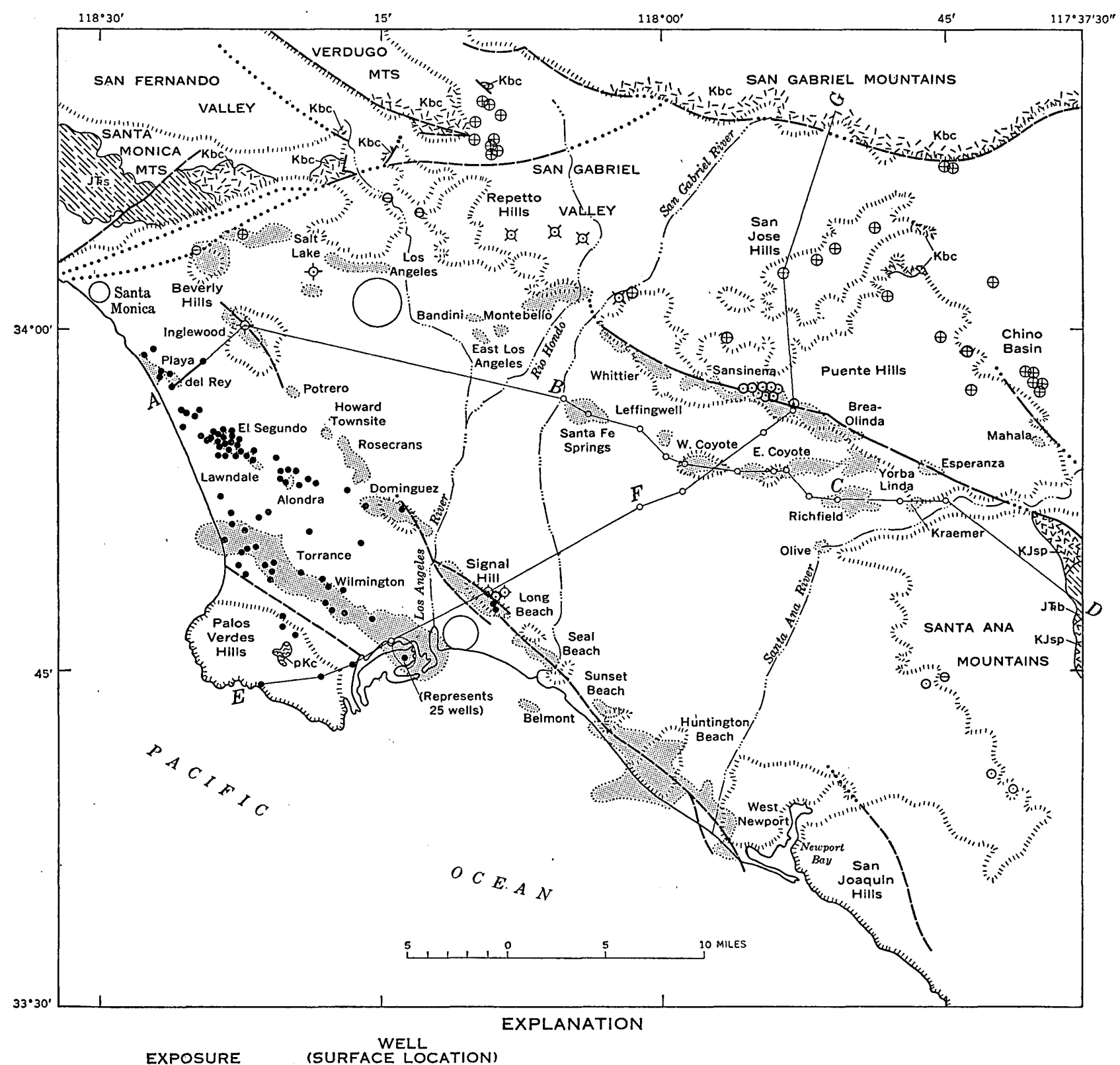

EXPOSURE (SURFACE LOCATION)

\begin{tabular}{|c|c|c|}
\hline 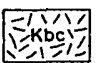 & $\oplus$ & \multirow{5}{*}{$\begin{array}{l}\text { EASTERN } \\
\text { BASEMENT } \\
\text { COMPLEX }\end{array}$} \\
\hline \multicolumn{3}{|c|}{ Granitoid intrusive rocks of early Late Cretaceous age } \\
\hline 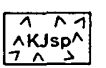 & $\odot$ & \\
\hline Santiago $P$ & $\begin{array}{l}\text { Peak Volcanics of Late Jurassic(?) to Early } \\
\text { Cretaceous(?) age }\end{array}$ & \\
\hline Nins: & $\theta$ & \\
\hline \multicolumn{2}{|c|}{$\begin{array}{l}\text { Metasedimentary rocks of Triassic(?) and Late Jurassic age } \\
\text { J下s, Santa Monica Slate } \\
\text { Jฬb, Bedford Canyon Formation }\end{array}$} & \\
\hline 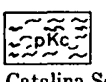 & 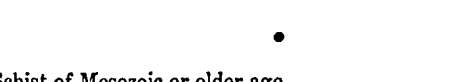 & $\begin{array}{l}\text { WESTERN } \\
\text { BASEMENT } \\
\text { COMPLEX }\end{array}$ \\
\hline
\end{tabular}

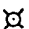

Well that bottoms in low-grade metasedimentary rocks of uncertain age and correlation $\phi$

Well that bottoms in low-grade metaigneous rocks of uncertain age and correlation

Approximate surface trace of major fault zone that cuts basement rocks

$$
\begin{aligned}
& \text { Will fild } \\
& \text { Oil field }
\end{aligned}
$$

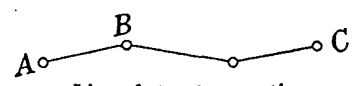

Line of structure section 
quartz dioritic or granodioritic composition (fig. 5), which intrude the Santa Monica Slate and which locally have a conspicuous gneissic texture. Some of these plutonic rocks, exposed in the hills just east of the Santa Monica Mountains, have been correlated by D. L. Lamar (unpub. data) with a similar rock in the nearby San Gabriel Mountains that has been dated by the lead-alpha method at 122 million years, or early Late Cretaceous (Larsen and others, 1958, p. 48, sample G-33). Several shallow wells drilled in the east part of the northwestern block bottom in similar plutonic rocks (fig. 5).

\section{CENTRAI BLOCK}

The basement rocks of the entire central block are questionably referred to the eastern complex on the basis of exposures in the Santa Ana Mountains and scattered well penetrations in marginal parts of the block (fig. 5). In the northern Santa Ana Mountains the complex includes the Bedford Canyon Formation, the Santiago Peak Volcanics, and intrusive plutonic rocks of the Southern California batholith (Larsen, 1948).

The Bedford Canyon Formation is exposed in the core and along the east flank of the northern Santa Ana Mountains. It consists of slightly metamorphosed dark well-bedded sandstone and siltstone of graywacke composition, containing minor limestone and pebble conglomerate. The formation is characterized by poorly to well-developed slaty cleavage and is intensely folded and jointed. Meager fossils from these rocks were originally assigned a Triassic age (Larsen, 1948, p. 18-19), but these fossils are now dated as Jurassic (Silberling and others, 1961; Imlay, 1963). Rocks equivalent to the Bedford Canyon Formation are widespread in the Peninsular Ranges south and east of the Santa Ana Mountains (Woodford, 1960, p. 404), as well as in the eastern Santa Monica Mountains. In the central block only one well, drilled along the southwest flank of the Santa Ana Mountains, bottoms in rocks referred to the Bedford Canyon Formation (fig. 5).

Rocks of the Santiago Peak Volcanics are exposed in a belt along the southwest flank of the northern Santa Ana Mountains (fig. 5) where they overlie the Bedford Canyon Formation with a pronounced angular unconformity, are intruded by rocks of the Southern California batholith, and are unconformably overlain by superjacent rocks. The rocks of the Santiago Peak Volcanics are chiefly andesitic breccias, flows, agglomerates, and tuffs, which commonly contain debris of the Bedford Canyon Formation near the base; they are poorly bedded, and commonly in- tensely altered and deeply weathered, and their thickness exceeds 1,000 feet. The outcrop belt of the volcanics broadens southeastward, and, although it is discontinuous, it evidently extends into northern Baja California (Woodford, 1960, p. 404). The age of the volcanics in the northern Santa Ana Mountains is evidently Late Jurassic(?) (post-Callovian) to latest Early Cretaceous(?). Durham and Allison (1960) have tentatively correlated the Santiago Peak Volcanics with the much thicker and more varied Alisitos Formation of northern Baja California, which contains interbedded fossiliferous marine sedimentary rocks of latest Early Cretaceous (Aptian and Albian) age. Three wells drilled along the southwest flank of the Santa Ana Mountains bottom in Santiago Peak rocks (fig. 5).

Granitoid plutonic rocks of the Southern California batholith, chiefly quartz diorite, granodiorite, and quartz monzonite, underlie large parts of the Transverse and Peninsular Ranges and widely invade the Bedford Canyon Formation and Santiago Peak Volcanics in the northern Santa Ana Mountains (see Woodford, 1960, p. 404). The plutonic rocks are the youngest basement rocks in the Los Angeles basin and contributed detritus to marine Upper Cretaceous (Turonian) strata exposed in the Santa Ana Mountains. Larsen and others $(1958$, p. 48-49) report leadalpha ages for 18 samples from rocks of the batholith in southern California, only two of which are from areas close to the Los Angeles basin. A sample of granodiorite from the central Santa Ana Mountains (Larsen sample G-32A) has an age of 120 million years. Quartz diorite from northern Baja California has an age of about 103 million years (Larsen samples BC-1-2, 1-4, 1-5, and SV-1) and intrudes volcanic and marine sedimentary rocks that contain fossils of latest Early Cretaceous (Aptian-Albian) age (Larsen and others, 1958, p. 46; Durham and Allison, 1960). Within the limits of error of the dating method, the ages of the southern California and Baja California samples are the same, and an early Late Cretaceous age is assigned to the entire batholith by Larsen and others (1958).

Only one well drilled in the central block of the Los Angeles basin is believed to bottom in granodiorite rocks of the Southern California batholith; this well is located in the northwesternmost part of the block (fig. 5). The other wells drilled in nearby parts of the block bottom in metaigneous rocks. A well drilled in the Inglewood oil field bottoms in both massive and foliated, intensely altered rhyolite(?) porphyry, and a well drilled near the Las Cienegas oil field 
bottoms at a relatively shallow depth in gneissic metadiorite. These two rocks are unlike any known from the western complex and are questionably assigned to the eastern complex.

\section{NORTHEASTERN BLOCK}

Basement rocks are exposed only in the northeast part of the northeastern block. The exposed rocks are biotite quartz diorite and granodiorite of the Southern California batholith. Similar basement rocks have been found in several wells drilled in the east part of the block (fig. 5). These rocks are intruded and overlain by biotite dacite porphyry of probable Miocene age and are unconformably overlain by middle Miocene volcanic rocks and middle and upper Miocene marine sedimentary rocks.

Eight wells drilled in the Brea-Olinda oil field near the southwest margin of the block bottom in foliated metavolcanic rocks tentatively correlated with the Santiago Peak Volcanics of the eastern basement complex. These metavolcanic rocks are unconformably overlain by marine strata of middle Miocene age. Two wells drilled in the westernmost part of the block bottom in metasedimentary rocks like the Santa Monica Slate, and four wells drilled in the southwest part of the block near the Repetto Hills bottom in phyllite or schist, of uncertain affinity, which are referred to the eastern basement. The basement rocks in these six wells are unconformably overlain by marine sedimentary rocks, chiefly of late Miocene age.

\section{SUPERJACENT ROCKS}

The superjacent rocks of the Los Angeles basin are known from extensive exposures around its margins and from thousands of wells drilled throughout the basin area. Detailed study of these exposures and wells by many geologists over a period of about 50 years has resulted in a complex stratigraphic nomenclature, in part because of lateral variations in lithology and thickness. To avoid the repeated use of different formal names for units that are partly or wholly equivalent, the superjacent rocks are here described informally in chronologic order. Furthermore, the Cenozoic epochs in California have not been satisfactorily correlated with those of Europe; the classification of the Cenozoic used in this report is based on correlation of fossil marine invertebrate faunas of western North America with those of the European standard section, as proposed by Weaver and others (1944) and Durham (1954). Summaries of the formal stratigraphic nomenclature based on this classification and brief descriptions of the rock units are presented in plates 1 and 2 .

\section{UPPER CRETACEOUS ROCKS}

The oldest superjacent rocks of the Los Angeles basin form a lithologically varied and locally thick succession of chiefly marine clastic sedimentary rocks of Late Cretaceous age. They are exposed in the northwestern block (Santa Monica Mountains) and in the east part of the central block (Santa Ana Mountains). They are also present beneath younger strata throughout the southeast part of the central block, and may occur in a narrow northwest-trending belt along the north flank of the central block (fig. 6). They are exposed also at the southeast margin of the northeastern block, but are known (or inferred) to be absent from other parts of the basin.

The lower 500 to 800 feet of superjacent rocks in both the Santa Ana and the Santa Monica Mountains contain poorly stratified nonmarine(?) red and green or white conglomerate and sandstone that grade laterally into Upper Cretaceous marine strata and are inferred to be of equivalent age (Popenoe and others, 1960, pl. 1, note 10).

The marine part of the Upper Cretaceous is an alternating succession of pebble-cobble conglomerate, coarse-grained feldspathic sandstone, and argillaceous siltstone and shale. In the Santa Monica Mountains this marine section includes as much as 75 percent hard compact massive pebble-cobble conglomerate; the remainder is interbedded shale, sandstone, limestone, and thick beds of pebbly sandstone. In the northern Santa Ana Mountains the marine part has been divided into four members of about equal thickness (Popenoe, 1942; see also pls. 1 and 2, col. 11). These members are, from base to top, conglomeratic sandstone and conglomerate, silty shale and argillaceous siltstone, massive coarse-grained sandstone and conglomerate, and fine-grained sandstone.

The Upper Cretaceous strata were deposited on an eroded surface and transgressed onto basement rocks in both outcrop areas; the top is also an erosional unconformity, below which the upper two members are locally missing in the Santa Ana Mountains.

The Upper Cretaceous section is about 1,000 feet thick in the eastern Santa Monica Mountains and increases in thickness westward to as much as 3,500 feet. In the Santa Ana Mountains the maximum exposed thickness is about 5,700 feet; farther southwest, where it is buried, wells have penetrated about 4,000 feet of this section without reaching the base. 

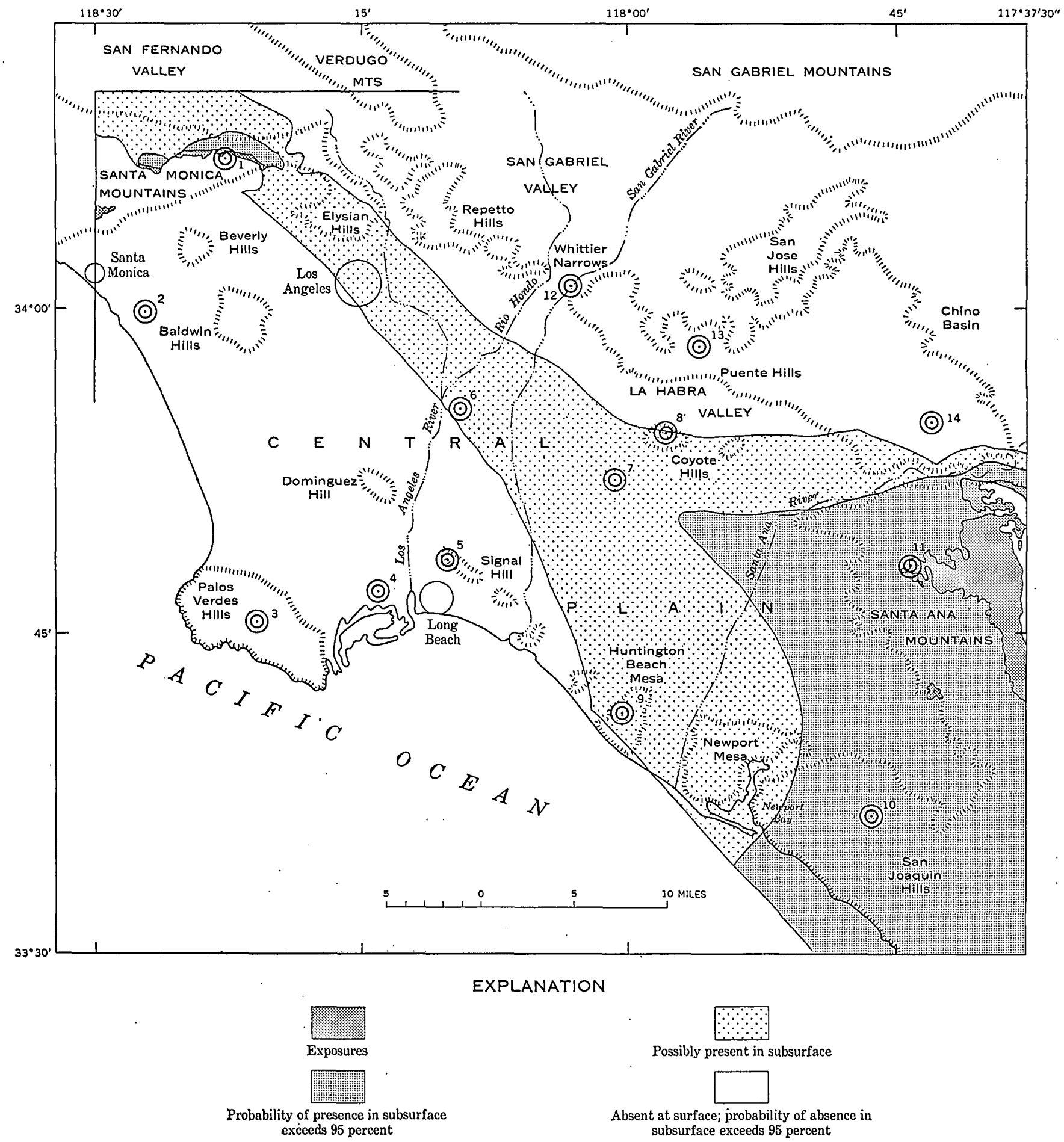

(2) 1

Location of numbered composite stratigraphic column

Fraure 6.-Distribution of Upper Cretaceous rocks in the Los Angeles basin. Location and number of each composite stratigraphic column are the same as in plates 1,2 , and 3 . 
Marine mollusks from both outcrop areas have been referred by Popenoe and others (1960, pl. 1, cols. 6 and 7) to the Turonian and Campanian Stages of the Late Cretaceous. Foraminifera from the lower part are tentatively assigned to the Coniacian and Santonian Stages.

The lithology and fossils of the lower part of the marine section in the southeast central block suggest deposition in a shallow transgressive sea, followed by deeper water sedimentation that included submarine slides. Strata of the upper part were probably deposited in a rapidly filling basin. Conglomerate in both lower and upper parts contains abundant detritus of eastern basement as well as other rocks evidently derived from areas to the north and east.

\section{PATEOCENE ROCKS}

The Paleocene is a heterogeneous succession of nonmarine and marine sedimentary rocks that are exposed in the northwestern block (Santa Monica Mountains), in the east and southeast parts of the central block (Santa Ana Mountains and San Joaquin Hills), and in the southeast extremity of the northeastern block. The Paleocene is present throughout most of the southeast central block and in the southeast part of the northeastern block. It may occur in a narrow northwest-trending belt along the north flank of the central block (fig. 7). It is either known or inferred to be absent in other parts of the basin. The unpatterned area in the southeast central block between localities 10 and 11 (fig. 7) may have been an area of nondeposition. The Paleocene strata in the adjacent San Joaquin Hills contain abundant detritus that presumably was derived from a structural high of Upper Cretaceous rocks along the southwest edge of the Santa Ana Mountains.

The Paleocene succession includes nonmarine sandstone and conglomerate, followed by marine siltstone, sandstone, and conglomerate. Exposures of the nonmarine part in the eastern Santa Monica Mountains are coarse-grained feldspathic sandstone and pebblecobble conglomerate. West of long $118^{\circ} 30^{\prime}$ W., a 2 to 4-foot bed of red-brown pisolitic clay locally occurs near the base. The Paleocene section thickens abruptly west of this meridian where it consists of marine siltstone, massive pebble-cobble conglomerate, fossiliferous sandstone, and discontinuous biostromal algal limestone.

In the Santa Ana Mountains the nonmarine part has a basal conglomerate that contains abundant detritus derived from Upper Cretaceous strata and rocks of the eastern basement complex. This conglomerate is overlain by nonmarine coarse-grained, poorly sorted feldspathic sandstone that contains abundant altered biotite and minor amounts of interbedded siltstone; a widespread 2- to 5-foot bed of red-brown pisolitic clay and quartz grit; and lenticular carbonaceous shale and low-grade lignite beds. In the southeast part of the Santa Ana Mountains a second thin clayey grit bed occurs. The nonmarine succession in parts of this area grades laterally and upward into concretionary fine- and medium-grained micaceous marine sandstone.

In both the northwest and southeast outcrop areas, the Paleocene rocks were deposited on a surface of erosion; however, in the Santa Ana Mountains the basal conglomerate overlaps Upper Cretaceous strata, and east of long $117^{\circ} 3712^{\prime} \mathrm{W}$. it rests in places on eastern basement. The upper contact in the southeast area is seemingly conformable with marine strata of Eocene age, but it may be a hiatus. Paleocene and Eocene strata are entirely nonmarine at places along the southwest slope of the Santa Ana Mountains and are separated arbitrarily.

In the eastern Santa Monica Mountains the nonmarine section is about 300 feet thick; it grades westward (west of long $118^{\circ} 30^{\prime}$ ) into marine strata and thickens abruptly to about 5,000 feet. In the Santa Ana Mountains the nonmarine section ranges from 800 to 1,500 feet in thickness; the marine section is 350 to 625 feet thick.

Mollusks from marine strata in both outcrop areas indicate a Paleocene age. The nonmarine section is presumably Paleocene (Woodring and Popenoe, 1945); parts of it grade laterally into marine strata.

A nearby source for the nonmarine part of the section is indicated by the abundant detritus derived from underlying strata and basement rocks. A few miles east of long $117^{\circ} 371^{\prime} 2^{\prime}$ W., just east of the Santa Ana Mountains, transported clay overlies thick residual claystone formed from igneous and metamorphic rocks of the eastern basement complex. This claystone presumably was more widespread in early Paleocene time and probably was a source for the transported clay. These features suggest prolonged chemical weathering of a stable area of low relief near base level and deposition of the nonmarine succession in a continental and lacustrine environment. A gradual transgression of shallow marine deposition in the central Santa Monica Mountains, the north part of the Santa Ana Mountains, and the San Joaquin Hills is indicated by the marine mollusks in parts of the section. 


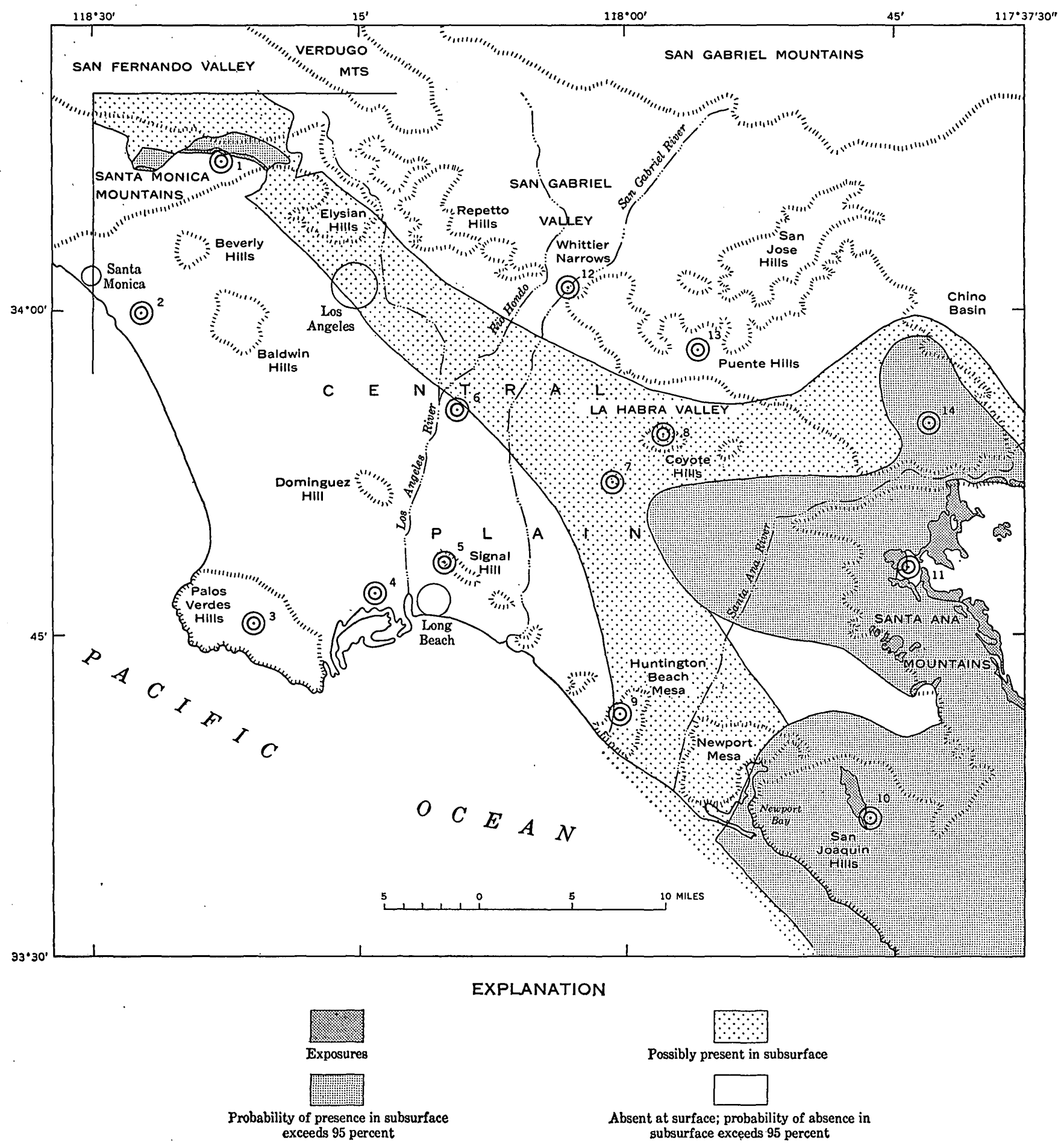

(๑)

Location of numbered composite

stratigraphic column

Fradre 7.-Distribution of Paleocene and Eocene rocks in the Los Angeles basin. Location and number of each composite stratigraphic column are the same as in plates 1,2 , and 3. 


\section{EOCENE ROCKS}

The Eocene section includes both marine and nonmarine sedimentary rocks, which are exposed only in the east and southeast parts of the central block (Santa Ana Mountains and San Joaquin Hills) ; marine Eocene strata also are exposed west of the basin (west of long $118^{\circ} 30^{\prime}$ W.) in the northwestern block (central Santa Monica Mountains). Eocene strata are buried throughout a large part of the southeast central block and the southeast part of the northeastern block. These strata may form a narrow northwest-trending belt along the north flank of the central block, but they are known (or inferred) to be absent in other parts of the basin (fig. 7).

In the Santa Ana Mountains the Eocene section includes a basal marine conglomerate and conglomeratic sandstone that contains well-rounded pebbles, cobbles, and boulders of volcanic porphyry, quartzite, hard sedimentary rocks, and less abundant fragments of quartz, chert, aplite, conglomerate, and plutonic rock. It contains a matrix and lenses of poorly sorted, coarse-grained to pebbly, feldspathic and micaceous sandstone. Bioclastic beds near the top of the basal conglomerate locally contain abundant calcareous algae and fragmentary marine invertebrates. Marine sandstone overlies the basal conglomerate in the north part of the Santa Ana Mountains and occurs at the base in the San Joaquin Hills. This sandstone is overlain by thick nonmarine(?) massive pebbly sandstone that in places contains fragments of silicified wood.

The Eocene section is seemingly conformable on underlying strata, but the fauna of the marine part suggests that a hiatus, presumably representing early Eocene time, separates the section from the uppermost marine beds of Paleocene age. The top is arbitrarily selected within a nonmarine section of repetitious lithology.

The outcrop thickness varies from 2,700 feet in the central part of the Santa Ana Mountains to 300 feet at the southeast end of those exposures. The basal conglomerate is 40 to 220 feet thick, the marine sandstone is as much as 675 feet thick, and the nonmarine(?) sandstone is as much as 2,000 feet thick.

The mollusk fauna from the marine beds is similar to one of middle Eocene age from the San Diego area. Woodring and Popenoe (1945) confidently assign the Santa Ana Mountains fauna to the later half of the California Eocene. Foraminifera are uncommon but suggest Mallory's (1959, table 19) Ulatisian Stage.
The basal conglomerate contains abundant large well-rounded fragments of plutonic and sedimentary rocks as well as a distinctive suite of colorful silicified volcanic porphyries and welded tuffs, some of which contain piedmontite. This distinctive conglomerate suite is present in Paleocene and Eocene strata in most parts of coastal California and has been much studied (Bellemin and Merriam, 1958). No certain source for this suite has been identified, but it may have been derived from a completely eroded source in the eastern basement north or east of the outcrop area. That this suite was derived from an offshore source seems less likely.

In the northern part of the Santa Ana Mountains and in the San Joaquin Hills, the lower part of the Eocene succession contains mollusks that indicate deposition in a shallow marine environment. The upper part probably is nonmarine and marks the inception of an important marine regression that persisted in the Los Angeles basin from late Eocene through Oligocene time.

UPPER EOCENE(?) TO LOWER MIOCENE ROCKS

A thick red-bed section of upper Eocene (?) to lower Miocene nonmarine strata, which is overlain by and interbedded with lower Miocene marine strata, is exposed only in the east and southeast parts of the central block (Santa Ana Mountains and San Joaquin Hills) and in the southeasternmost part of the northeastern block. It is also exposed west of the Los Angeles basin (central Santa Monica Mountains). It is buried throughout much of the southeast part of the central block and the southeast part of the northeastern block; a small remnant is also preserved beneath younger strata in the northeastern block between localities 12 and 13 (fig. 8). This section probably is absent from most of the southwestern and northwestern blocks. The unpatterned area between localities 10 and 11 in the southeast central block (fig. 8) is probably due to erosion.

In the north part of the Santa Ana Mountains, the red-bed section is nonmarine sandstone and conglomerate; in the central and southwest part of the mountains, nonmarine conglomerate and sandstone interfinger with marine strata. In the adjacent San Joaquin Hills the section is much thicker, consisting of nonmarine conglomerate and sandstone below and marine sandstone and siltstone above (compare cols. 10 and 11, pls. 1 and 2). In the Santa Ana Mountains, the complex relations of marine and nonmarine strata 


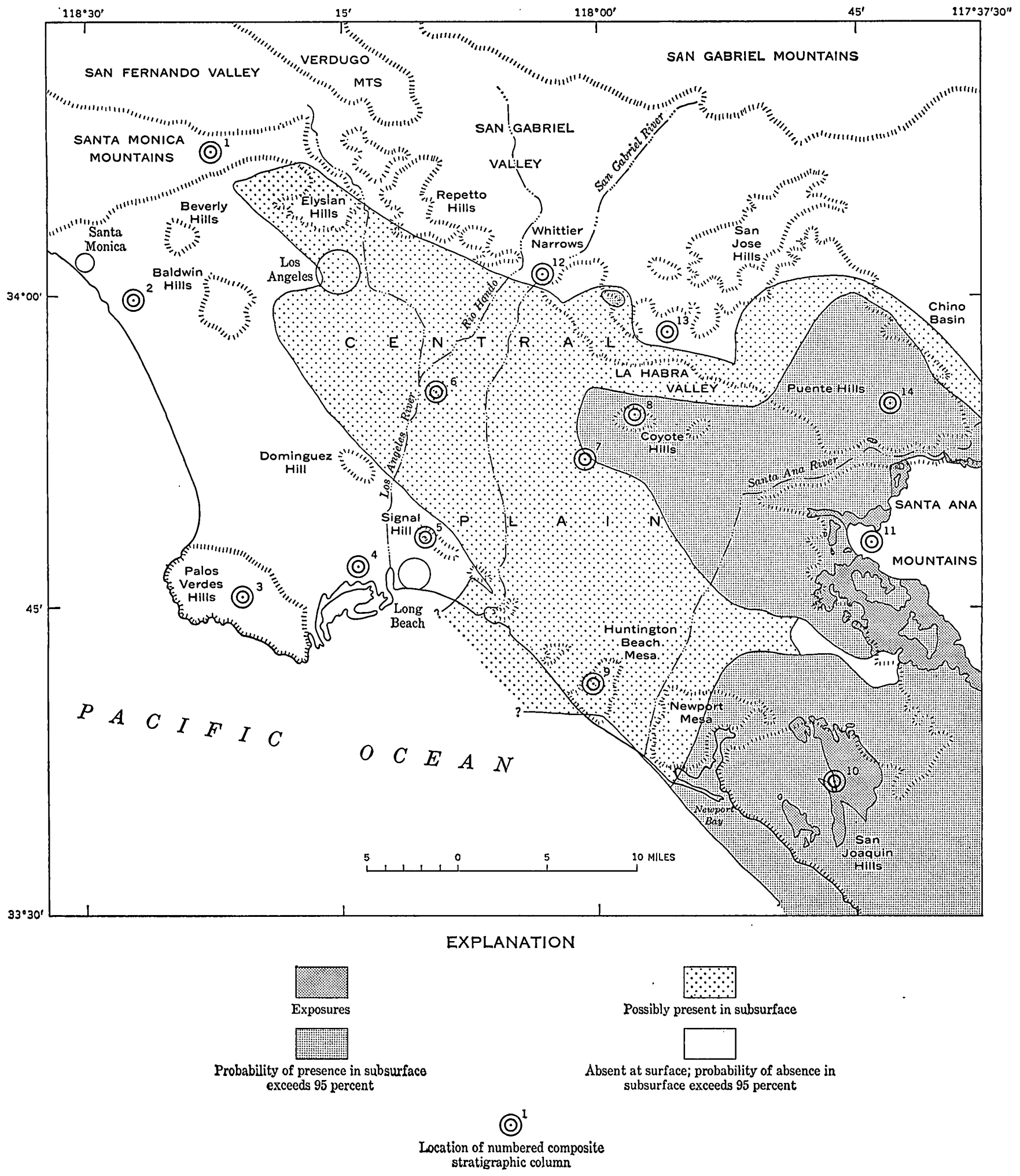

Figure 8.-Distribution of upper Eocene(?) to lower Miocene rocks in the Los Angeles basin. Location and number of each composite stratigraphic column are the same as in plates 1,2 , and 3 . 
prevent subdivision of the succession (Schoellhamer and others, 1954), but in the San Joaquin Hills a lower nonmarine part and an upper marine part are mapped (Vedder and others, 1957).

The nonmarine part of the section in the northern Santa Ana Mountains includes a basal conglomerate and an overlying massive sandstone. The basal conglomerate contains pebbles and cobbles of volcanic rocks, quartzite, plutonic rocks, and hard sandstone in a matrix of coarse-grained clayey sandstone. The overlying strata are conglomeratic lithic sandstone in a clayey matrix. Interbedded with the sandstone are layers of red-brown earthy sand and clayey siltstone.

In the central Santa Ana Mountains, marine sandstone interfingers in the upper part of the dominantly nonmarine section and along the southwest flank of the mountains the upper part is largely marine. The section along the southwest flank of the mountains includes pebble conglomerate, reddish-brown pebbly sandstone, and clayey siltstone. Here the marine tongues consist of calcareous sandstone and friable clayey sandstone.

In the central San Joaquin Hills, nonmarine strata in the lower part consist of variegated sandstone and conglomeratic sandstone, and interbedded reddishbrown and greenish-gray sandy claystone. These strata grade upward into marine beds, which include sandy siltstone and fine- to coarse-grained sandstone.

In exposures in the southeast part of the Los Angeles basin, the base of the section seemingly grades down into nonmarine(?) strata at the top of the Eocene section. The base and inland margins of the marine part grade into nonmarine strata, and the top of the succession grades into or is unconformably overlain by marine middle Miocene strata.

In the Santa Ana Mountains the section is about 3,000 feet thick, both in the north part where it is entirely nonmarine, and along the southwest flank where the upper 600 feet are marine. In the San Joaquin Hills the nonmarine part is about 2,450 feet thick, and the overlying marine part is as much as 3,800 feet thick.

Mollusks from the upper marine beds in the southeast Los Angeles basin are of early Miocene age, but the base of the section apparently grades into nonmarine strata of possible late Eocene age. Durham (1954, p. 24, col. 4) indicates that they are separated by a hiatus that represents late Eocene and part of Oligocene time. If so, some of the nonmarine strata represent part, but perhaps not all, of Oligocene time.

The nonmarine strata contain the same distinctive suite of pebbles and cobbles as occur in the under- lying Eocene rocks: numerous rounded colorful pebbles and cobbles of hard volcanic porphyry and welded tuff, as well as quartzite and other rocks.

The interfingering marine and nonmarine strata along the southwest slope of the Santa Ana Mountains mark the fluctuating northeast shoreline of the shallow early Miocene sea and the inception of a thick marine upper Tertiary section.

\section{MIDDLE MIOCENE ROCKS}

The middle Miocene rocks of the Los Angeles basin form an extremely varied succession of volcanic and marine sedimentary rocks, which in most places can be separated into two partly coextensive sequences. The lower sequence consists of marine clastic and organic sedimentary rocks that contain Foraminifera of Kleinpell's (1938) Relizian Stage; this sequence is exposed chiefly in the southwestern block (Palos Verdes Hills), the northwestern block (Santa Monica Mountains), and the southeast part of the central block (Santa Ana Mountains and San Joaquin Hills). The upper sequence in most parts of the basin includes widespread extrusive igneous rocks, marine clastic and organic sedimentary rocks, and, locally, a unique schist breccia; the sedimentary rocks contain Foraminifera of Kleinpell's Luisian Stage. Parts of the succession are exposed in all blocks of the basin, as well as locally in the foothills of the San Gabriel Mountains along the north margin of the basin (fig. 9).

Middle Miocene rocks are buried northeast of the Santa Monica Mountains in the northeastern block; they occur only around the margins of the southwestern block but are present throughout most of the central block northwest of the Santa Ana River except where they have been eroded (near localities 5 and 7, fig. 9). In the northeastern block they probably occur only east of the San Gabriel River.

\section{LOWER SEQUENCE}

The lower sequence of middle Miocene rocks is exposed in the northwestern block (Santa Monica Mountains), southwestern block (Palos Verdes Hills), and the east and southeast parts of the central block (Santa Ana Mountains and San Joaquin Hills). In the eastern Santa Monica Mountains this sequence consists of marine sandstone, siltstone, and minor amounts of conglomerate (Hoots, 1931; Durrell, 1954, 1956). In places along the south and west margins of the Palos Verdes Hills, silty, sandy, and siliceous shale with minor amounts of schist breccia and tuff are exposed (Woodring and others, 1946).

In the Santa Ana Mountains the lower sequence consists of sandstone, pebbly sandstone, conglomerate, 


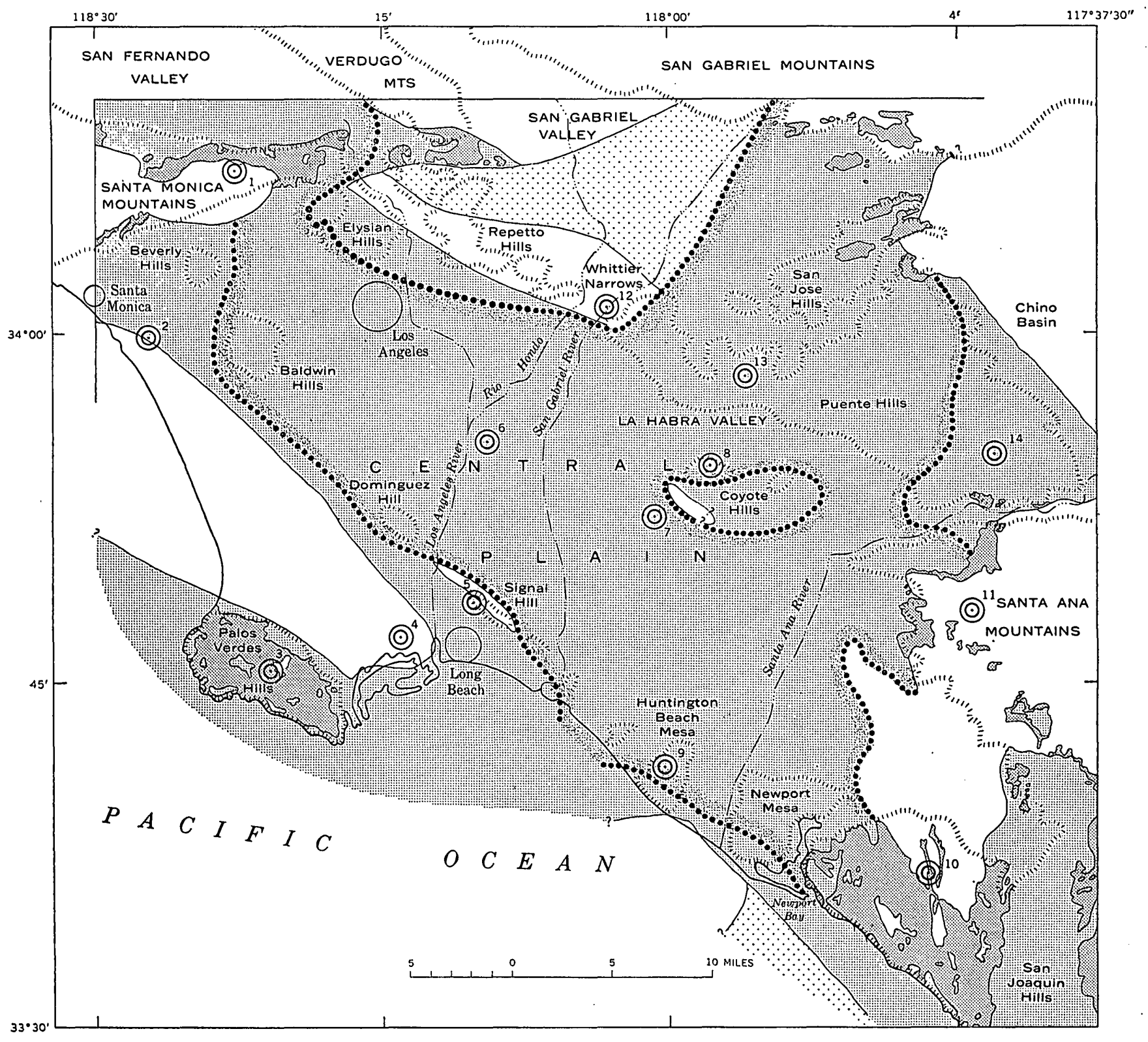

EXPLANATION

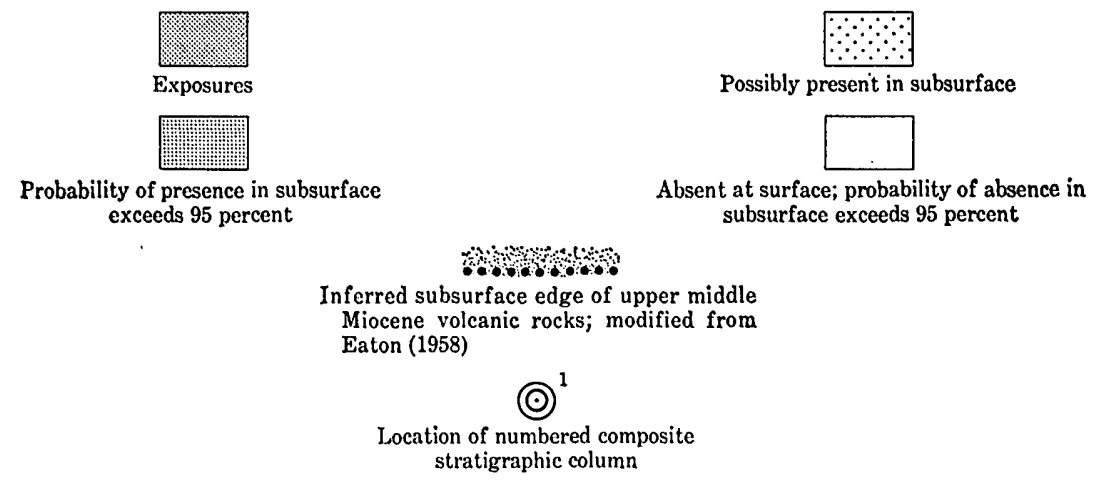

Figure 9.-Distribution of middle Miocene rocks in the Los Angeles basin. Location and number of each composite stratigraphic column are the same as in plates 1,2 , and 3. 
interbedded micaceous siltstone, and minor amounts of tuff and limy siltstone. In the southeastern foothills (near long $117^{\circ} 371^{\prime} 2^{\prime} \mathrm{W}$.), basal beds locally contain Catalina Schist detritus. In the central part of the nearby San Joaquin Hills, the lower sequence has been further divided into three named members (pls. 1 and 2). The lower member is conglomeratic sandstone and grit, the middle is dark-gray siltstone and interbedded sandstone that contains detritus of Catalina Schist, and the upper is tuffaceous siltstone and sandstone that contains interbedded andesite flows and sedimentary breccias of andesite. In the southwest San Joaquin Hills a few exposures of siliceous shale and siltstone contain Catalina Schist detritus.

In the eastern Santa Monica Mountains the base of the lower sequence is an unconformity, which locally cuts down to Paleocene strata. In the Santa Ana Mountains and San Joaquin Hills the sequence generally grades down into marine strata of early Miocene age, but in the north part of the Santa Ana Mountains it rests on nonmarine strata. Farther southeast (south and east of long $117^{\circ} 3711^{\prime}$ W.; lat $33^{\circ} 371^{\prime} 2^{\prime}$ N.), the base is unconformable on marine lower Miocene strata. In most of the basin the top of the lower sequence is an unconformity, except in the Palos Verdes Hills and part of the San Joaquin Hills, where it grades into the upper sequence.

The maximum thickness of the lower sequence is about 1,000 feet in the eastern Santa Monica Mountains, about 300 feet along the south margin of the Palos Verdes Hills, about 2,500 feet in the Santa Ana Mountains, and about 7,000 feet in the San Joaquin Hills.

In the Santa Monica Mountains, Santa Ana Mountains, and San Joaquin Hills, the lower sequence locally contains marine mollusks that indicate a middle Miocene age; most sections locally contain Foraminifera that indicate an early middle Miocene age (Relizian Stage of Kleinpell, 1938). Lower middle Miocene (Relizian) strata were reported from two wells drilled in the San Jose Hills (Olmsted, 1950, p. 195), and equivalent rocks are present in several wells drilled in the Puente Hills.

Lower middle Miocene rocks in the eastern Santa Monica Mountains (northwestern block) evidently were derived from eastern basement sources and were deposited in a shallow marine environment. The shale in the Palos Verdes Hills and the southwest part of the San Joaquin Hills is interbedded with sandstone that contains much angular Catalina Schist detritus that was derived from a western basement source. Catalina Schist detritus is absent in the lowest member in the San Joaquin Hills, but it is extensive and locally abundant in the upper two members. However, the lower sequence of the nearby Santa Ana Mountains contains Catalina Schist detritus only in the southeastern foothills; elsewhere material derived from eastern basement sources prevails. The agencies that transported the Catalina Schist detritus evidently did not penetrate inland beyond the present southwest margin of the Santa Ana Mountains.

\section{OPPER SEQUENCE}

The upper sequence of middle Miocene rocks is exposed in marginal parts of all the structural blocks of the basin. In the northwestern block (Santa Monica Mountains), east part of the central block (Santa Ana Mountains), and northeastern block (San Jose Hills), the lower part of the sequence consists of extrusive igneous rocks. Except in the Santa Ana Mountains, the volcanics are overlain by marine conglomerate, sandstone, siltstone, and shale of late middle Miocene age. In the southwestern block (Palos Verdes Hills) the sequence is chiefly organic siliceous shale and silty shale. In the San Joaquin Hills similar shale and siltstone overlie and are interbedded with schist breccia.

In the eastern Santa Monica Mountains, andesitic and basaltic flows, tuffs, and breccias that contain interbedded foraminiferal sediments form the lower part of the upper sequence (Hoots, 1931; Durrell, 1954, 1956). These volcanic rocks are followed by marine conglomerate, sandstone, siltstone, and shale. The conglomerate consists of blocks of basalt, fragments of Upper Cretaceous sedimentary rocks, boulders of quartz diorite from the eastern basement, and beds of basalt detritus derived from the underlying volcanic rocks.

In the low hills east of the Santa Monica Mountains, the lower part of the sequence is crudely bedded breccia-conglomerate and conglomeratic sandstone that contain abundant detritus of eastern basement (D. L. Lamar unpub. data). These strata are overlain by massive to well-bedded sandstone and pebbly sandstone.

In the southwestern block the upper sequence is exposed only in the Palos Verdes Hills. The section consists of siliceous shale, chert, limestone, and minor amounts of siltstone, diatomite, phosphatic shale, and tuff; the lower part of this section contains several thick sills of basalt (Woodring and others, 1946). The shale overlies either western basement rocks, locally derived schist breccia and conglomeratic sandstone, or shale of the lower sequence.

In the San Joaquin Hills the upper sequence includes thick lenticular breccias composed of angular 
chips, slabs, and blocks of Catalina Schist and minor amounts of interbedded bioclastic sandstone and clayey siltstone. Overlying the schist breccia, and locally intertongued and interbedded with it, are organic and siliceous shale and clayey siltstone. Interbedded in the siltstone and shale are limy concretionary beds, limy bioclastic sandstone beds, and lenses of sandstone, conglomerate, or breccia; most of these coarsegrained interbeds contain varying amounts of Catalina Schist detritus. Several thin interbeds of andesitic tuff are also present.

In the Santa Ana Mountains the upper sequence is represented by olivine basalt flows, palagonite tuff and tuff breccia, and andesitic flows and flow breccias, which locally contain interbedded foraminiferal siltstone (Yerkes, 1957). Similar volcanics are present above schist breccia lenses in several wells drilled along the southwest flank of the central block.

In the San Jose and Puente Hills the upper sequence is locally thick and consists of volcanic rocks, which are overlain by and interbedded with marine conglomerate, sandstone, and siltstone. The volcanic rocks are flows, flow breccias, tuffs, and tuff breccias of basaltic to rhyolitic, but chiefly of andesitic, composition (Shelton, 1946, 1955). Where exposed in these hills, the volcanic rocks overlie the eastern basement, but in the subsurface to the south they overlie Tertiary strata. Interbedded in the upper part of and overlying the volcanic rocks in the San Jose Hills are conglomerate, sandstone, and foraminiferal siltstone. In the San Jose Hills a thin altered andesitic flow locally forms the top of the succession. Several small fault-bounded remnants of similar sandstone and conglomerate crop out in the nearby foothills of the San Gabriel Mountains. Two small exposures of the upper sequence at the southeast margin of the Puente Hills consist of massive pebbly feldspathic sandstone.

The base of the upper sequence is unconformable at most places in the basin. In the eastern Santa Monica Mountains the sequence lies on rocks as old as Paleocene and contains intraformational unconformities. In the low hills east of the mountains the sequence rests unconformably on eastern basement. On the north slope of the Palos Verdes Hills it rests unconformably on western basement, but along the south and west margins of the hills it grades down into similar strata of the lower sequence; a northward onlap is thus indicated. In the San Joaquin Hills, schist breccia lies unconformably on older Miocene strata and transgresses faults of large displacement. Here shale and siltstone of the upper sequence not only transgress the breccia and older Miocene strata but also contain schist breccia lenses. Where exposed in the San Jose Hills, the volcanic rocks rest on eastern basement. The basal beds of the overlying sedimentary strata are interbedded with, or unconformable on, the volcanic rocks.

In the Palos Verdes Hills and in parts of the San Joaquin Hills, the upper sequence grades into upper Miocene strata; elsewhere on the periphery of the basin the upper contract is an erosional unconformity (pls. 1 and 2), and in places it is a pronounced angular unconformity.

In the eastern Santa Monica Mountains the upper sequence is as much as 9,000 feet thick; in the Palos Verdes Hills, about 700 feet; in the San Joaquin Hills, about 3,500 feet; and in the Santa Ana Mountains, no more than 850 feet. In the San Jose Hills the sequence is about 5,000 feet thick, but in the nearby subsurface it thickens to nearly 6,700 feet.

The upper sequence in all parts of the basin locally contains marine mollusks that suggest a middle Miocene age and Foraminifera that indicate a late middle Miocene age (Luisian Stage of Kleinpell). However, some of the schist breccia lenses in the San Joaquin Hills probably are older.

The volcanics at the base of the upper sequence in the eastern Santa Monica Mountains are the eastern extension of a much thicker accumulation that is exposed in the central and west parts of the mountains. The volcanics include interbedded marine sedimentary rocks. Sedimentary strata that overlie the volcanics contain abundant detritus of all older rocks and were evidently derived from areas underlain by eastern basement. The fossil mollusks indicate a protected shallow marine environment for parts of the sequence.

In the Palos Verdes Hills much of the middle Miocene section contains abundant Catalina Schist detritus, which indicates derivation chiefly from a western basement source. Here the upper sequence contains mollusks and Foraminifera that indicate deposition in a shallow marine environment and a water depth of 600 to 3,000 feet (Woodring and others, 1946, p. $39-40)$.

The upper sequence in the San Joaquin Hills contains extensive and locally very thick lenses of schist breccia which extend discontinuously along the coast from the central part of the hills to Oceanside, about 35 miles to the southeast. The breccia underlies most of the southwest flank of the central block as far northwest as the Long Beach oil field, but it lenses out northeast of the San Joaquin Hills; nowhere is it preserved in the adjacent Santa Ana Mountains. The breccia coarsens and thickens from north to south and was evidently derived chiefly as extensive submarine 
landslides or mud flows from an elongated northwesttrending ridge of Catalina Schist exposed somewhere southwest of the present coast, most probably a ridge elevated along or southwest of the Newport-Inglewood zone. The siltstone and shale that overlie this breccia also contain lenses of sandstone, conglomerate, and schist breccia. The foraminiferal faunas from these strata (Smith, 1960) indicate that the basal beds are younger toward the northeast and that the shale and siltstone probably accumulated in water deeper, and in places much deeper, than 600 feet. Shallow-water mollusks from sandstone lenses in the San Joaquin Hills must have been transported from nearshore areas that lay to the northeast. This section is equivalent in age and lithologically similar to the upper sequence in the Palos Verdes Hills and probably shares a common source.

The volcanic rocks exposed in the western foothills of the Santa Ana Mountains are of late middle Miocene age and are widespread beneath younger rocks in the subsurface of the central block. In both outcrop and wells the volcanics contain interbedded fossiliferous sedimentary rocks; at least the lower part accumulated in a shallow marine environment.

In the Puente and San Jose Hills only the upper sequence is preserved. The locally thick volcanic rocks in the northeast part of the basin accumulated under subaerial and shallow submarine conditions. The interbedded and overlying sedimentary rocks were derived from eastern basement sources to the north and northeast and were deposited in shallow marine water at or near the northeast shoreline (Woodford and others, 1946).

At least three sources for the widespread and locally thick upper middle Miocene volcanic rocks of the Los Angeles basin area can be identified, but, despite extensive study (Shelton, 1954, 1955; Yerkes, 1957; Eaton, 1958) these sources cannot be precisely located. One source may have been northwest of the basin, another near its northeast border, and a third in its southeast part. The area covered by the volcanics (fig. 9) has been estimated at about 700 square miles and the volume of rock involved at a minimum of 140 cubic miles (Shelton, 1954).

\section{INTRUSIVE ROCKS}

Intrusive igneous rocks of middle Miocene age occur in several parts of the basin. In the Santa Monica Mountains, dikes, sills, and irregular masses of medium- to coarse-grained diabase, basalt, and andesite widely intrude all rocks older than middle Miocene. These intrusions are more abundant, larger, and coarser grained in older rocks, and in most places were emplaced along faults. In the Palos Verdes Hills, several thick sills of hypersthene andesite and basalt intrude the lower part of the upper sequence. In the San Joaquin Hills, numerous long thin dikes of phaneritic hypersthene andesite, which are emplaced along faults, radiate northward from a point near the offshore extension of the Newport-Inglewood zone. In the western foothills of the Santa Ana Mountains, several thin andesite dikes cut Miocene volcanic rocks; a few basaltic dikes cut sedimentary rocks elsewhere in the mountains. Intrusive rocks of middle Miocene age are seemingly absent in the northeastern block.

\section{UPPER MYOCENE ROCKS}

Upper Miocene strata of the Los Angeles basin form a widespread and locally very thick succession of very fine to coarse grained, chiefly clastic marine sedimentary rocks that locally contain intrusive igneous rocks. The sedimentary rocks are divided informally into two largely contemporaneous facies. The thickest and most extensive of these is a succession of micaceous shale and siltstone, sandstone, and pebble conglomerate that is termed the eastern facies. The western facies is much thinner and is chiefly shale, diatomite, and siltstone.

Upper Miocene rocks are buried throughout most of the basin except in the east part of the northwestern block, in a wedge-shaped area (unpatterned in fig. 10) in the southeast part of the central block, and in the north part of the northeastern block. (See fig. 10.)

$$
\text { EASTERN FACIES }
$$

The eastern facies of upper Miocene rocks is exposed in the Santa Monica Mountains, the Elysian Hills just north of downtown Los Angeles, the Puente and San Jose Hills, the Santa Ana Mountains, and east of the San Joaquin Hills. These rocks on the north flank of the eastern Santa Monica Mountains have been divided into two members by Hoots (1931, p. 102-115). The lower member is coarse-grained feldspathic sandstone with a thin basal conglomerate that contains abundant detritus from the eastern basement. Organic shale, platy white porcelaneous shale, and minor amounts of bituminous shale and tuff overlie the basal beds. The upper member consists of porous diatomaceous shale and interbedded clayey siltstone, fine-grained sandstone, and minor amounts of tuff. 


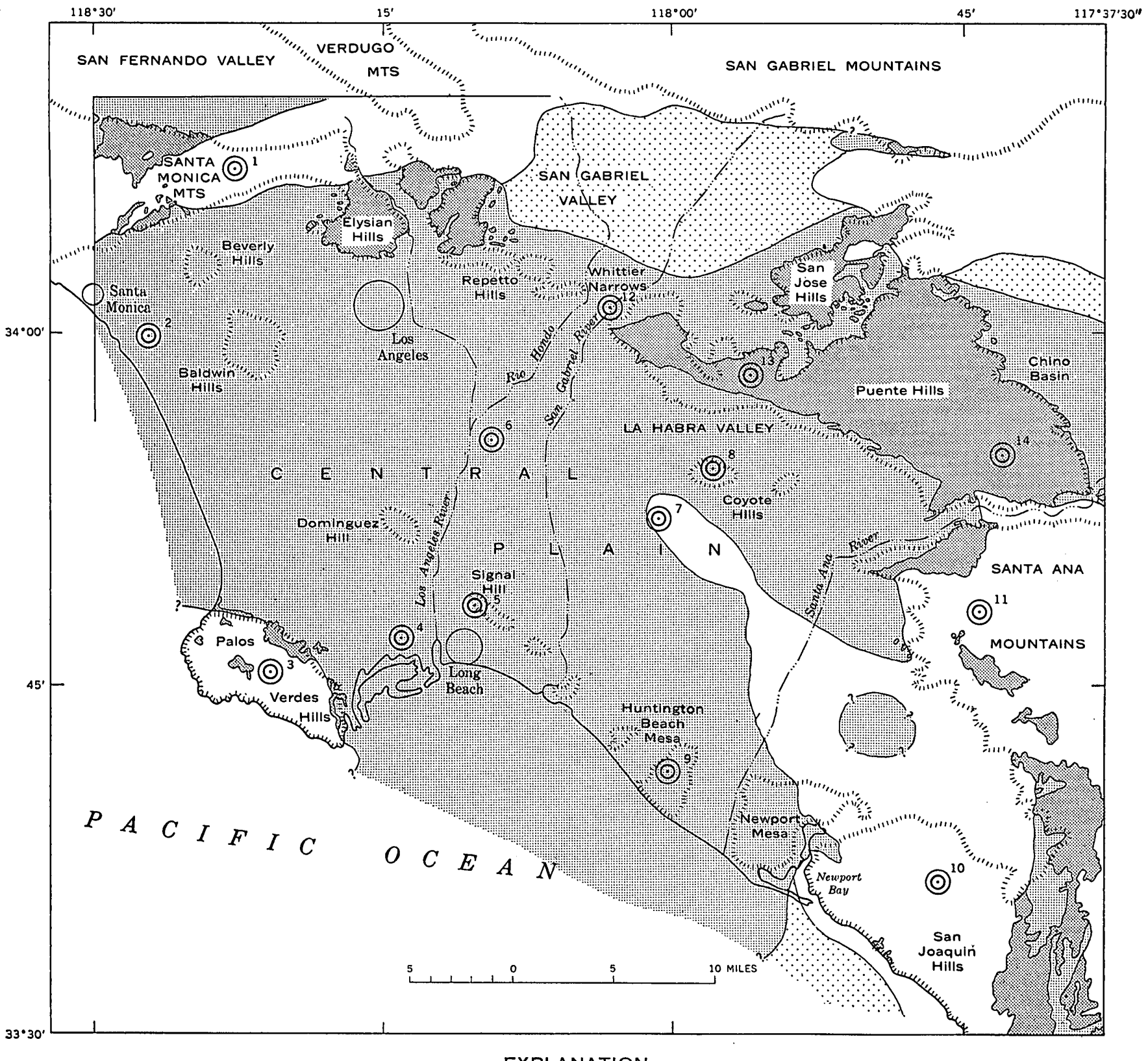

EXPLANATION

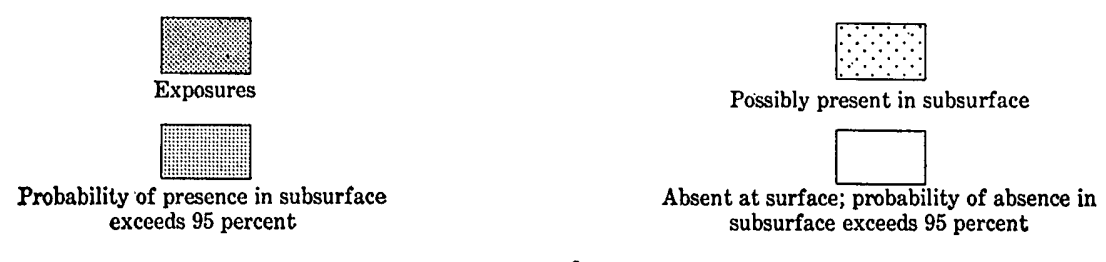

$0^{2}$

Location of numbered composite

stratigraphic column

Figure 10.-Distribution of upper Miocene rocks in tho Los Angeles basin. Location and number of each composite stratigraphic column are the same as in plates 1, 2, and 3. 
A somewhat similar succession is exposed in the Elysian Hills in the northwest part of the central block (D. L. Lamar, unpub. data) ; it consists of thinto thick-bedded sandstone and minor amounts of interbedded siltstone and shale. The sandstone is very fine to coarse grained, friable, and very poorly sorted. The upper part is chiefly thin-bedded diatomaceous siltstone and very fine grained sandstone containing minor interbedded medium- to coarse-grained sandstone.

The eastern facies is widely exposed and attains its maximum known thickness in the northeastern block. Parts of the San Jose Hills exposures have been mapped by Shelton $(1946,1955)$ and Olmsted (1950), and parts of the Puente Hills exposures have been mapped by Woodford and others (1945), Daviess and Woodford (1949), Durham and Yerkes (1959), and Yerkes (1960). The Puente Hills succession south of lat $34^{\circ} \mathrm{N}$. has been divided into four named members. (See pls. 1 and 2; Schoellhamer and others, 1954.) The lowest mumber consists of laminated to platy micaceous siltstone that contains interbedded feldspathic sandstone, local hard limestone beds and concretions, and thin tuff beds. This member grades upward into massive to locally thick-bedded concretionary feldspathic sandstone that contains interbedded clayey siltstone and pebble-cobble conglomerate. In the north part of the hills, the sandstone member contains very large boulders of eastern basement. The sandstone member characteristically grades into the adjoining members. The third member is platy to thin-bedded diatomaceous and sandy siltstone that contains interbedded sandstone and pebble conglomerate. The uppermost member consists of intertongued micaceous siltstone and coarse-grained sandstone that contains as much as 30 percent interbedded conglomerate. These four members have also been mapped at the east margin of the central block in the Santa Ana Mountains.

Northeast of the San Joaquin Hills the eastern facies is represented by laminated clayey siltstone, finegrained sandstone, and coarse-grained conglomeratic sandstone. Diatomaceous shale, tuff, and limestone concretions occur in places in the lower part. Southeast of the hills these rocks grade into underlying shale and siltstone of the western facies.

The eastern facies in the Santa Monica Mountains lies with pronounced unconformity on all older rocks of the superjacent sequence and in places on eastern basement; the angular discordance is as much as $90^{\circ}$. In the southeast part of the Puente Hills the eastern facies is unconformable on middle Miocene strata with an angular discordance of $30^{\circ}$; in the north part of the Puente Hills and in the adjoining areas the lowest member is absent, and younger members are unconformable on middle Miocene sedimentary or volcanic rocks or on eastern basement. Along the west slopes of the Santa Ana Mountains the lower two members of the facies are widespread and locally overlap middle Miocene rocks; the upper two members are preserved only farther north. Northeast of the San Joaquin Hills the eastern facies grades southward into shale and siltstone of the western facies and is unconformable on middle Miocene rocks.

In the eastern Santa Monica Mountains the eastern facies is as much as 5,500 feet thick, and in the Elysian Hills to the southeast it is as much as 6,400 feet thick; the maximum known thickness is in the Puente Hills, where it is about 13,400 feet. In the Santa Ana Mountains the thickness is about 9,400 feet, and northeast of the San Joaquin Hills it is about 1,275 feet.

Foraminifera from the eastern facies are of late Miocene age and include Kleinpell's Mohnian and Delmontian Stages (Woodford and others, 1945; Daviess and Woodford, 1949; Natland and Rothwell, 1954).

Clastic material in the eastern facies in all parts of the basin eivdently was derived from sources to the north or northeast. The source of the coarse-grained detritus in the Santa Monica Mountains has been tentatively identified as an area in the San Gabriel Mountains about 30 miles northeast of the exposures (Sullwold, 1960). Directional features in the eastern facies at the Elysian Hills indicate a source to the northwest (D. L. Lamar, unpub. data). Clastic fragments in the Puente and San Jose Hills probably were derived chiefly from eastern basement sources similar to those exposed at the northeast margin of the hills and in the mountains to the north and northeast (Woodford and others, 1946, p. 553-559). The upper two members in the Santa Ana Mountains are southward or southeastward extensions of the thick Puente Hills succession; a thick coarse-grained sandstone body east of the San Joaquin Hills also probably was derived from the northeast.

Mollusks from the base of the eastern facies in the Santa Monica Mountains are rock-clinging forms that lived at the foot of cliffs (W. P. Woodring, in Hoots, 1931 , p. 111), perhaps on an island or shallow submarine ridge. Sandstone beds, mainly in the upper parts of the lower member of the facies on the north flank of the mountains, were deposited chiefly by turbidity currents on a submarine fan in water about 3,000 feet deep (Sullwold, 1960). Sandy strata in the facies in the Elysian and Puente Hills contain graded bedding, load casts, and other sedimentary fea- 
tures that suggest deposition by turbidity currents; such currents evidently were active along the north and east margins of the basin during most of late Miocene time. The inland margins of the Puente and San Jose Hills probably were the approximate northeast shoreline of the late Miocene sea (Woodford and others, 1946). Foraminifera from the Puente Hills and Santa Ana Mountains indicate deposition in water deeper than 2,000 feet. Foraminifera from well cores in upper Miocene strata at the southwest margin of the central block include species which suggest that the water progressively deepened from about 1,600 feet early in late Miocene time to more than 3,000 feet at the end of the epoch (Natland and Rothwell, 1954, p. 40). These conditions evidently prevailed over all but the marginal parts of the basin or basins in which the eastern facies accumulated.

\section{WESTERN FACIES}

The western facies of upper Miocene rocks consists chiefly of fine-grained sedimentary rocks that are exposed only in the southwestern block (Palos Verdes Hills) and in the southeast part of the central block (San Joaquin Hills). The western facies is characterized by organic sedimentary rocks, by lack of thick sandstone units, by northward or eastward transgression, and by varying amounts of western basement detritus.

In the Palos Verdes Hills the western facies consists, in ascending order, of phosphatic and bituminous shale, diatomaceous shale and mudstone, and radiolarian mudstone; minor constituents include chert, limestone, vitric tuff, and, in the lower part, blueschist sandstone (Woodring and others, 1946, p. 14).

In the San Joaquin Hills the western facies is massive to thin-bedded diatomite, diatomaceous mudstone, and siltstone that contains interbedded soft laminated siltstone, vitric tuff, and minor Catalina Schist detritus. Lenses of sandstone, conglomerate, and breccia occur near the southeast end of the hills.

In both outcrop areas the western facies grades up from similar strata of late middle Miocene age, and the younger and older strata cannot everywhere be separated lithologically. In the Palos Verdes Hills the top of the western facies seemingly grades into lower Pliocene strata, but the contact is interpreted as disconformable on the basis of missing foraminiferal zones (Woodring and others, 1946, p. 41). The top of the western facies in most of the San Joaquin Hills is an erosional unconformity; southeast of the hills the upper part is conformably overlain by lower Pliocene strata.

In the Palos Verdes Hills the western facies is between 700 and 1,400 feet thick; at Newport Bay it is nearly 1,200 feet thick, and southeast of the San Joaquin Hills it is about 2,000 feet thick.

Foraminifera from the western facies in the Palos Verdes and San Joaquin Hills are of late Miocene age (Mohnian and Delmontian Stages). Faunal assemblages from the facies suggest (1) that the lower part in both areas accumulated in water more than 1,800 feet deep and (2) that the upper part was deposited in water which deepened progressively to more than 3,000 feet (Woodring and others, 1946, p. 39-40; Smith, 1960).

Northward and eastward onlap of the western facies is suggested by Catalina Schist detritus in the lower part and by a progressive decrease in age of the basal beds from south to north in the Palos Verdes Hills (Woodring and others, 1946) and from southwest to northeast in the San Joaquin Hills (Smith, 1960). At least the lower part was derived mainly from western basement. Northward and northeastward onlap evidently continued during the latest part of late Miocene time, and the deposits accumulated in water of greater depth than at any previous time; however, little western basement detritus occurs in the upper part of the western facies.

INTRUSTVE ROCKS

Sill-like bodies of coarse-grained diabase (gabbro to diorite) are locally exposed north of the Whittier fault zone near the south margin of the central Puente Hills. These rocks have been penetrated by many wells in a belt about 1.6 miles wide and about 15 miles long north of the fault zone (section $F-G$, pl. 4). The bodies are as much as 650 feet thick and cut downward from west to east along the fault zone, across about 4,000 feet of strata that range in age from early late Miocene to middle Miocene. On the coastal side of the San Joaquin Hills, some small silllike bodies of fine-grained andesite intrude shale and siltstone of early late Miocene age.

\section{PLIOCENE ROCKS}

The Pliocene succession in the Los Angeles basin consists of repetitiously interbedded fine to coarse clastic marine strata that are probably more than 14,000 feet thick in the deeper parts of the central block. Basinwide subdivision and correlation of these strata on lithology alone is not feasible, owing to uniformity resulting from continuous deposition in deep water in some areas and to a lack of deep-well data in the central part of the basin. However, the succession has been divided into several foraminiferal zones (Wissler, 1943, pl. 5) which are used by oil companies for correlation. Molluscan assemblages from the succession suggest a twofold chronologic division 
(Woodring, 1938, p. 22). In the northeast part of the basin, lithologic variations and an extensive unconformity permit division of the Pliocene succession into two named members (Daviess and Woodford, 1949; Woodford and others, 1954; Durham and Yerkes, 1959). These two sequences have been projected provisionally into the central parts of the basin (pl.4) on the basis of regional geophysical studies and well data in the marginal areas.

\section{LOWER SEQTENCE}

The lower sequence of Pliocene rocks is exposed in the southwestern block (northeast margin of the Palos Verdes Hills), at the north margin of the central block (downtown Los Angeles-Elysian Hills area and the Repetto Hills), along the northeast and east margins of the central block (south margin of the Puente Hills and the west end of the Santa Ana Mountains), in the southeast part of the central block (San Joaquin Hills), and in the south-central part of the northwestern block (western Puente Hills and southwestern San Jose Hills). The sequence is buried in the southwestern block, in the central block northwest of the Santa Ana River where it is thickest, and in the south-central part of the northeastern block (fig. 11).

At the northwest end of the central block near downtown Los Angeles, the lower sequence includes sandy siltstone and minor interbedded conglomerate exposed in scattered cuts (Soper and Grant, 1932). The thickest outcrop section of Pliocene strata is in the Repetto Hills at the north margin of the central block where the section consists of massive to poorly bedded siltstone, silty fine-grained sandstone, and thin lenticular conglomerate. Here the section cannot be divided lithologically, but the abundant foraminiferal assemblages provide a basis for well-defined faunal zonation (Natland and Rothwell, 1954, p. 36).

The lower sequence is well exposed in parts of the Puente Hills. Along the southwest slope of the hills it is massive silty fine- to coarse-grained sandstone and interbedded massive conglomerate composed largely of angular to subrounded pebbles of lightcolored plutonic rocks. Conglomerate beds at the base contain detritus of platy white (upper Miocene) siltstone. The north slopes of the western Puente Hills are formed in part by silty fine-grained sandstone and interbedded pebble conglomerate (Daviess and Woodford, 1949) that are assigned to the lower sequence. At the southwest end of the nearby San Jose Hills the sequence is interbedded siltstone, sand- stone, and pebble conglomerate (Olmsted, 1950). Strata in a syncline at the southeast end of the Puente Hills may be of early Pliocene age (Woodring, 1938, p. 4), but these strata cannot be satisfactorily separated lithologically from underlying upper Miocene strata.

At the northwest end of the Santa Ana Mountains the lower sequence is micaceous sandy siltstone that contains minor pebble conglomerate at and near the base. At the southeast end of the San Joaquin Hills, equivalent strata are micaceous sandy siltstone and fine-grained sandstone; these strata are lithologically similar to upper Miocene strata and hence are omitted from the distribution map (fig. 11). Near Newport Bay the lower sequence consists of massive fine-grained sandstone and sandy siltstone. Along the northeast margin of the Palos Verdes Hills it is soft massive glauconitic siltstone that contains some Catalina Schist detritus.

The lower sequence is extensive in the subsurface of the central block where it attains its greatest thickness. Conrey (1958) subdivided it in the subsurface of the central and southwestern blocks on the basis of well cores and electric logs. The dominant rock is arkosic sandstone that grades from medium grained at the northeast to fine grained at the southwest (fig. 12). The sandstone layers are most abundant in the central parts of the basin, where they contain graded bedding and other sedimentary features attributed to deposition by turbidity currents. Interbedded units of micaceous siltstone and sandy shale decrease in grain size and increase in organic content seaward across the basin. Conglomerate and pebbly sandstone are thick and abundant in the north-central and northeast parts of the central block. The conglomerates are formed chiefly of angular to subrounded pebbles, cobbles, and boulders of light-colored plutonic rock. Other constituents of the sequence include limestone nodules, volcanic ash, and chert.

In the Puente Hills the lower sequence evidently lies conformably on upper Miocene strata, but in the Santa Ana Mountains there is a local unconformity at the base. In the southeast part of the San Joaquin Hills this sequence grades down into lithologically similar upper Miocene strata, whereas near Newport Bay it lies unconformably on strata of late and middle Miocene age. In the Palos Verdes Hills the lower sequence is abnormally thin and rests disconformably on upper Miocene strata. An erosional unconform- 

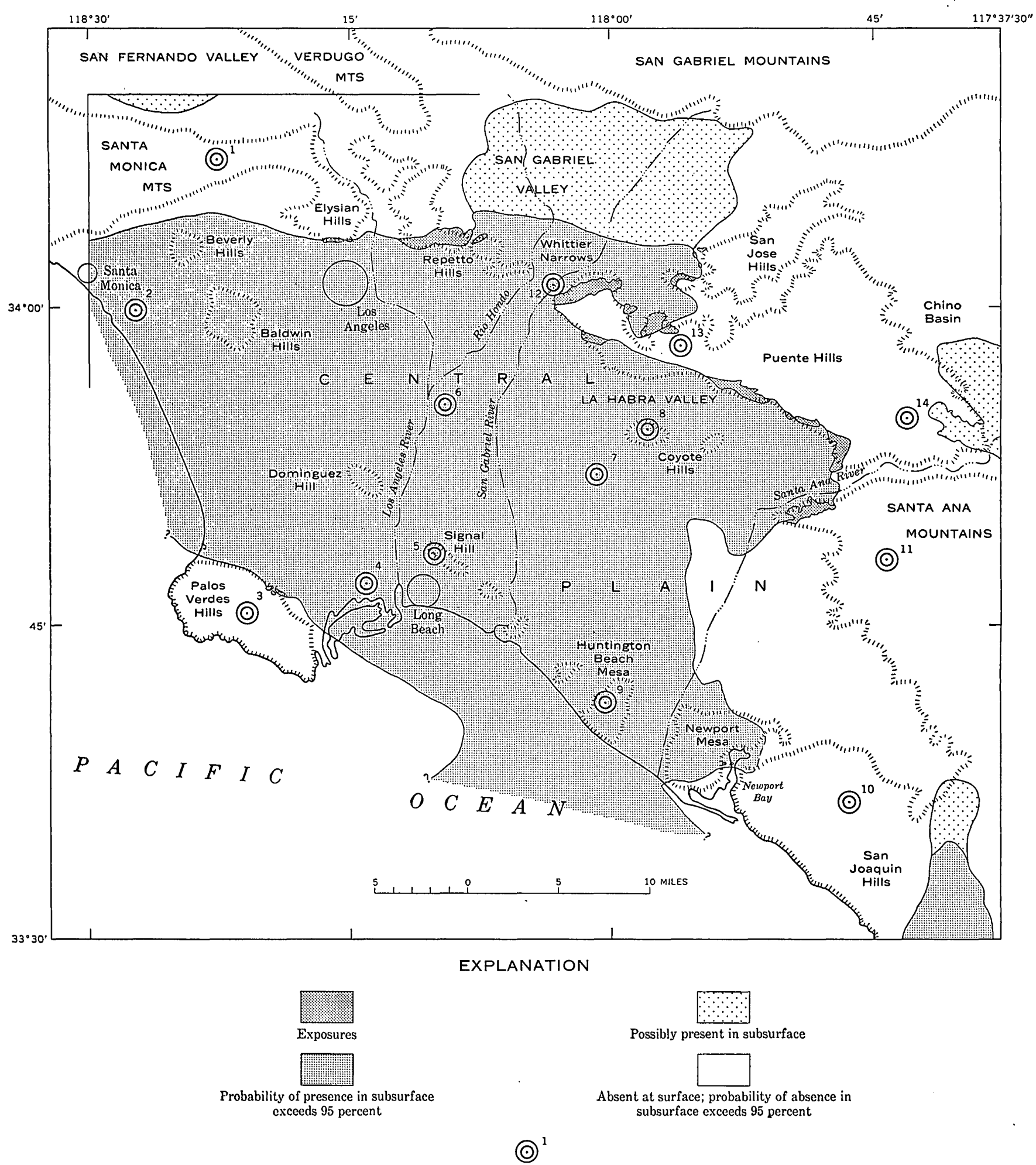

Location of numbered composite stratigraphic column

Fiqure 11.-Distribution of lowor Pliocene rocks in the Los Angeles basin. Location and number of each composite stratigraphic column are the same as in plates 1. 2, and 3. 

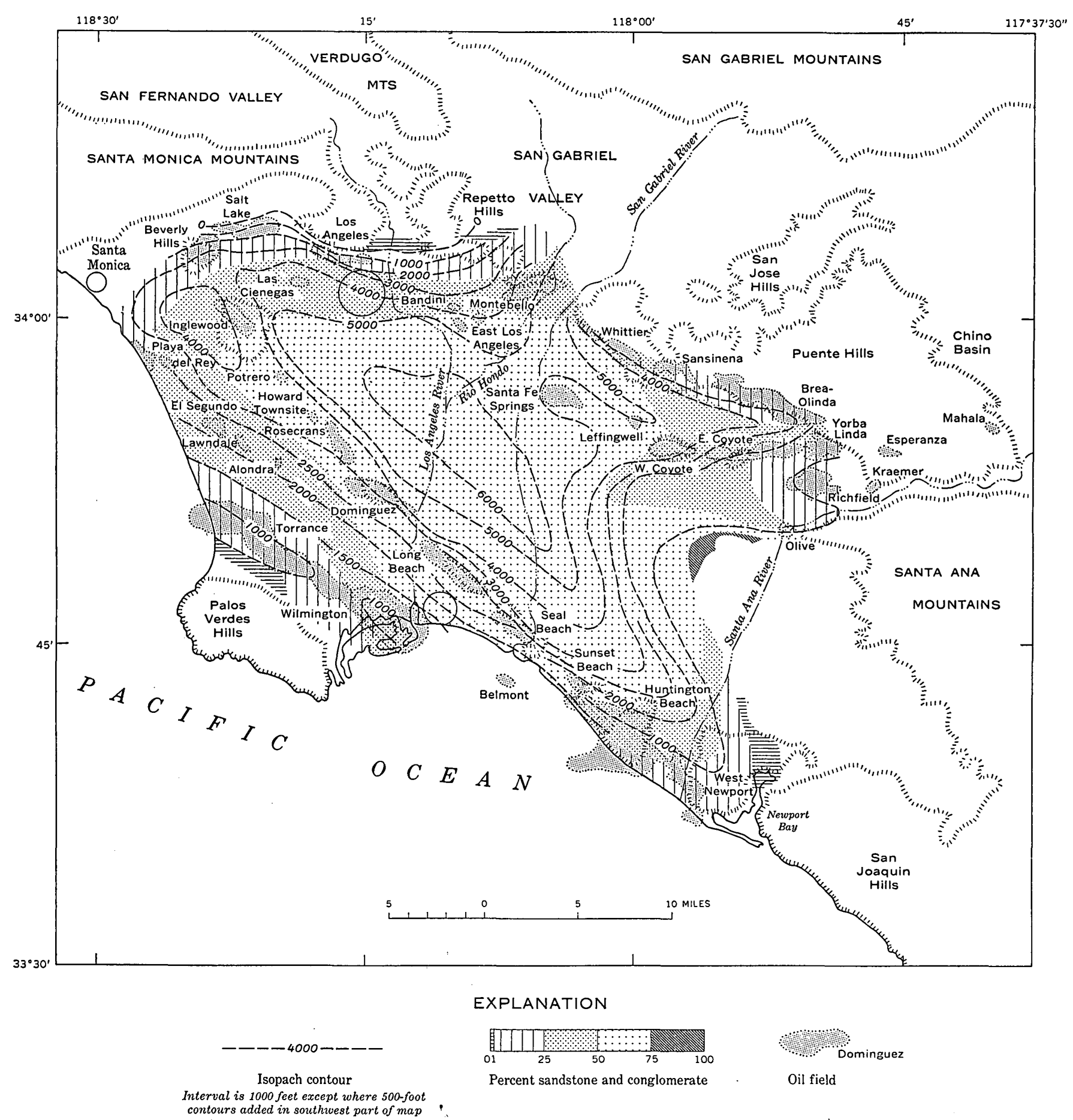

FIGURE 12.-Lithofacies and thickness relations of lower Pliocene rocks of the Los Angeles basin. Lithofacies from Conrey (1958); isopachs based on results of this investigation.

ity with an angular discordance of $5^{\circ}$ to $10^{\circ}$ marks the top in most exposures, except in the Repetto Hills.

The lower sequence is about 850 feet thick in the partial section exposed in the downtown Los AngelesElysian Hills area at the northwest end of the central block; it is between 2,500 and 3,000 feet thick in the Repetto Hills section to the east. The thickness is between 2,000 and 2,600 feet in the Puente Hills, about 700 feet in the partial section in the Santa Ana Mountains at the east edge of the central block, and about 800 feet at Newport Bay near the southeast margin of the block. The lower sequence is only 
about 150 feet thick in the partial section at the northeast margin of the Palos Verdes Hills in the southwestern block. In contrast, the sequence probably attains a thickness of 6,400 feet in the deep part of the central block where it underlies more than 11,000 feet of younger strata (pls. 1, 2, and 4).

The lower sequence contains early Pliocene molluscan and foraminiferal faunas (Woodring, 1938; Natland and Rothwell, 1954).

Rock types in conglomerates of the lower sequence are like older sedimentary and eastern basement rocks exposed in the highlands at the margin of the basin and were probably derived primarily from the San Gabriel Mountains, the Puente Hills, and areas within and east of the Santa Ana Mountains (Edwards, 1934; Bellemin, 1940; Olmsted, 1950; Kundert, 1952). The principal entry of detritus into the depositional basin was probably through a channel near the present eastern Repetto Hills at the north margin of the central block; from here the detritus swept westward and southward into the deeper and continuously subsiding parts of the central basin (Conrey, 1958).

Foraminifera from such widely separated areas as Newport Bay, Palos Verdes Hills, Long Beach oil field, downtown Los Angeles, and the Repetto Hills indicate deposition in water that deepened from about 3,000 feet at the end of Miocene time to between 4,500 and 6,000 feet near the end of early Pliocene time (Natland and Rothwell, 1954, p. 40; Barbat, 1958 , p. 72). During this interval the central part of the basin probably subsided about 6,200 feet (table 1 ; fig. 13).

The lower sequence contains mollusk assemblages that suggest a bathymetric division into three facies based on the assumption that the fossils lived at the same depth as closely related Recent species (Woodring, 1938, p. 12-16). One is a widely distributed deep-water facies $(2,000-4,000 \mathrm{ft})$; the second is an intermediate-depth facies around the periphery of the central block; and the third is a shallow-water facies (intertidal zone to $600 \mathrm{ft}$ ) near the north and west margins of the basin. In parts of the area an admixture of species representative of the three different facies suggests proximity to land and probably results from transport of the shallow-water forms into deeper water. This zonation indicates that the basin of early Pliocene time was analogous to modern deepwater $(2,000-6,000 \mathrm{ft})$ basins on the continental borderland (Emery, 1960).

\section{OPPER SEQUENCE}

The upper sequence of Pliocene rocks is exposed in places along the north margin of the central block (downtown Los Angeles-Elysian Hills area, the Repetto Hills, and the southwest slopes of the Puente Hills), in the east part of the block (west end of the Santa Ana Mountains), in the southeast part of the block (east of the San Joaquin Hills and at Newport Bay), and in the south-central and west parts of the northeastern block (north slopes of the western Puente Hills and locally in the low hills west of the San Gabriel Valley). The sequence is extensive in the subsurface of the southwestern and central blocks and is locally present in the subsurface of the south-central part of the northeastern block (fig. 14).

In the downtown Los Angeles-Elysian Hills area, the upper sequence consists of sandy siltstone and minor interbedded conglomerate (Soper and Grant, 1932). In the Repetto Hills to the east it forms the upper part of a repetitious section of massive to poorly bedded sandy siltstone, silty fine-grained sandstone, and minor interbedded conglomerate. The thickest exposed section is along the southwest slopes of the Puente Hills, where it consists of massive fineto coarse-grained sandstone containing abundant interbedded grit, pebbly sandstone, and conglomerate. The basal conglomerate there contains locally abun-

TABLE 1.-Relation between thickness, water depth, and subsidence during deposition of the superjacent rocks in the deep part of the central block, Los Angeles basin.

\begin{tabular}{|c|c|c|c|c|c|c|c|}
\hline \multirow{3}{*}{ Interval } & \multicolumn{2}{|c|}{ Present situation } & \multicolumn{5}{|c|}{ Situation during deposition (Inferred) } \\
\hline & \multirow{2}{*}{$\underset{\text { thickness }_{(\text {feet })^{1}}^{\text {Maximum }}}{\text { Mand }}$} & \multirow{2}{*}{$\begin{array}{c}\text { Altitude } \\
\text { of base } \\
\text { (feet } \\
\text { subsea) }\end{array}$} & \multirow{2}{*}{$\begin{array}{l}\text { Depth of } \\
\text { water } \\
\text { (feet) }\end{array}$} & \multirow{2}{*}{$\begin{array}{c}\text { Subsidence } \\
\text { during } \\
\text { interval } \\
\text { (feet) }\end{array}$} & \multirow{2}{*}{$\begin{array}{l}\text { Length of } \\
\text { interval } \\
\text { (millions of } \\
\text { years) }\end{array}$} & \multicolumn{2}{|c|}{$\begin{array}{l}\text { Net rates (feet per } \\
\text { million years) }\end{array}$} \\
\hline & & & & & & Deposition & Subsidence \\
\hline $\begin{array}{l}\text { Plelstocene and Recent } \\
\text { Late Pliocone } \\
\text { Early Pliocene } \\
\text { Lato Miocene } \\
\text { Early and Midöle Míocene } \\
\text { Pre-Míocene. }\end{array}$ & $\begin{array}{l}4,500 \\
7,900 \\
6,400 \\
5,200 \\
3,200 \pm \\
5,000 \pm\end{array}$ & $\begin{array}{l}4,400 \\
12,300 \\
18,700 \\
23,900 \\
27,100 \pm \\
32,100 \pm\end{array}$ & $\begin{array}{c}0-900 \\
900-4,000 \\
3,200-6,000 \\
1,600-3,200 \\
0-1,600 \\
0-250\end{array}$ & $\begin{array}{l}3,500 \\
\mathbf{4}, 800 \\
\mathbf{7}, 200 \\
\mathbf{6}, 800 \\
\mathbf{4}, \mathbf{5 5 0} \\
\mathbf{5 , 2 5 0}\end{array}$ & $\begin{array}{r}3.0 \\
4.5 \\
5.0 \\
6.5 \\
11.5 \\
63.0\end{array}$ & $\begin{array}{r}1,500 \\
1,756 \\
1,280 \\
800 \\
278 \\
79\end{array}$ & $\begin{array}{r}1,167 \\
1,067 \\
1,440 \\
1,046 \\
396 \\
83\end{array}$ \\
\hline
\end{tabular}

1 Estimates based on unpublished seismic data and regional subsurface studies, this investigation.

9 Modifled from Natland and Rothwell (1954, p. 40)

Based on Evernden and others (1964, p. 167); and unpublished data.

4 Rates of deposition in the Santa Monica and San Pedro basins immediately off shore have averaged about $3,565 \mathrm{ft}$ (after compaction) per million years over the last 10,000 years (Emery, 1960, p. 254,262). 


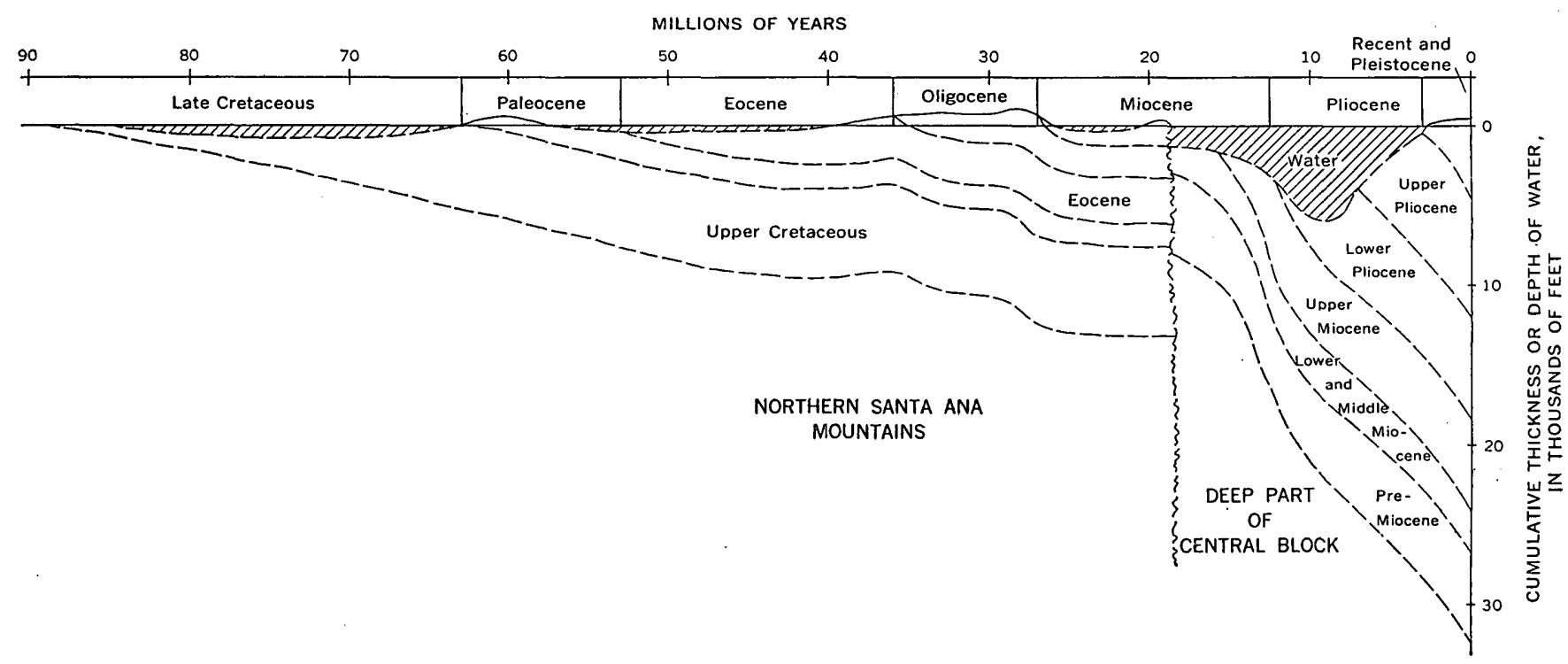

FraUre 13.-Diagram of relation between thickness, water depth, and time for two parts of the central block during deposition of superjacent rocks. Vertical distance between curves represents present maximum thickness; slope of curves represents rate of subsidence relative to present sea level, and position of curves represents Inferred absolute subsidence during time intervals. Based on table 1; modified from Emery (196n, p. 135).

dant platy white (upper Miocene) siltstone debris and diabase debris.

In the northwest part of the Puente Hills and in the San Jose Hills, the upper sequence is sandy siltstone, sandstone, and interbedded pebble conglomerate (Daviess and Woodford, 1949; Olmsted, 1950). In the northeastern block west of the San Gabriel Valley, rocks in small fault block may belong to the upper sequence. These strata consist of interbedded massive to poorly bedded soft micaceous sandstone, conglomeratic sandstone, and pebble-cobble conglomerate. In the foothills of the San Gabriel Mountains at the north margin of the basin, the sequence may be represented by thick nonmarine sandy conglomerate (Shelton, 1955, p. 76-77). Equivalent sediments probably attain a much greater thickness in the subsurface of the San Gabriel Valley in the central part of the block.

Exposures of the upper sequence in the Santa Ana Mountains consist of sandstone and conglomerate. East of the San Joaquin Hills the sequence is poorly consolidated siltstone, sandstone, and conglomerate; the basal beds are thin discontinuous calcareous grit, breccia, and conglomerate that contain some debris of (Miocene) siliceous shale and Catalina Schist. The uppermost part, at some localities, may be nonmarine. Near Newport Bay the sequence is massive silty fine-grained sandstone and sandy siltstone.

Relations at the base of the upper sequence reflect varying degrees of tectonic unrest in different parts of the basin. In the downtown Los Angeles-Elysian Hills area an unconformity truncates underlying beds beds with a discordance of $5^{\circ}$ to $10^{\circ}$ (Wissler, 1943, p. 213). An extensive erosional unconformity also occurs at the base along the south slopes of the Puente Hills. In the northeastern block the sequence is evidently conformable on older strata. East of the San Joaquin Hills it is unconformable on strata of late Miocene and early Pliocene age, whereas near Newport Bay it overlaps early Plioceno strata onto middle Miocene strata and contains at least one unconformity.

In the downtown Los Angeles-Elysian Hills area the upper sequence is about 425 feet thick; in the Repetto Hills to the east, about 2,800 feet; along the southwest slopes of the Puente Hills, as much as 3,400 feet; at the west end of the Santa Ana Mountains, about 100 feet; and in the San Joaquin Hills, between 350 and 800 feet. Along the northwest slopes of the Puente Hills the thickness is about 1,400 feet; , it is about 790 feet at the southwest end of the San Jose Hills, and about 1,480 feet in the fault-bounded remnant west of the San Gabriel Valley. In contrast, the sequence is inferred to attain a maximum thickness of about 7,900 feet in the subsurface of the central block (pl. 4).

Foraminifera occur in many places in the upper sequence, and mollusks are locally abundant. These 

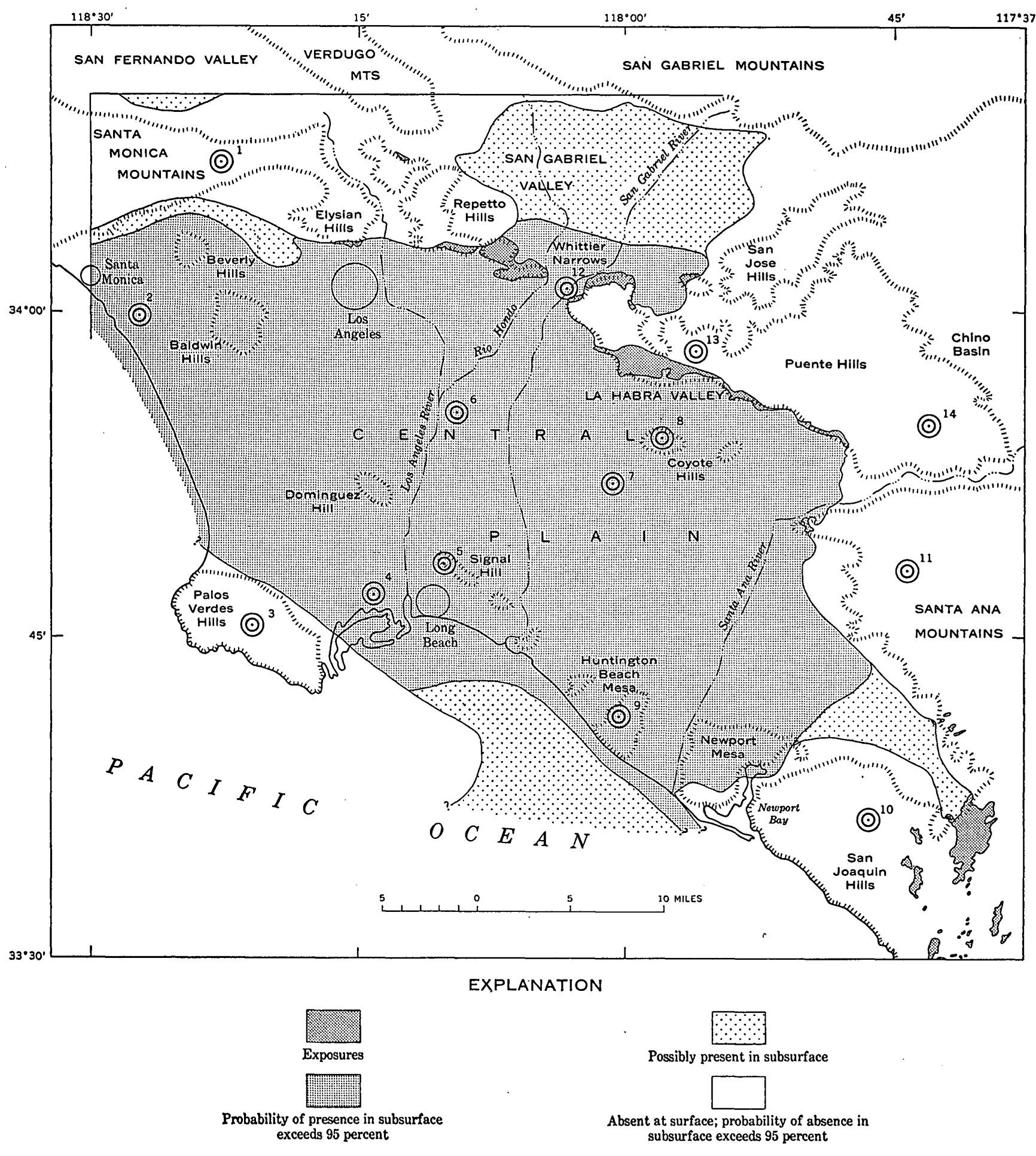

$\left(^{3}\right.$

Location of numbered composite stratigraphic column

Fiovgs 14.-Distribution of upper Plocene rocks in the Los Angeles basin. Location and number of each composite stratigraphio column are the same as In plates 1, 2, 
fossils rather definitely indicate a late Pliocene age in the downtown Los Angeles-Elysian Hills area and Repetto Hills (Soper and Grant, 1932, p. 1050-1067; Wissler, 1943, p. 213; Natland and Rothwell, 1954, p. 38), in the northwest Puente Hills area (Woodford and others, 1954, p. 73), along the southwest slopes of the Puente Hills (Vedder, 1960, p. B327), and in the San Joaquin Hills (Natland and Rothwell, 1954, p. 36 ; Vedder, 1960).

The detritus in conglomeratic phases of the upper sequence is derived chiefly from older rocks exposed around the inland margins of the basin of deposition. In the southwest Puente Hills the conglomerates locally contain debris of platy white (upper Miocene) siltstone derived from rocks that underlie most of the hills to the north. In the San Joaquin Hills, conglomerate and breccia at the base contain detritus of Catalina Schist and siliceous shale that was also locally derived.

Mollusks from the upper sequence in the northwest, north-central, northeast, and southeast parts of the basin suggest deposition in water less than 600 feet deep (Vedder, 1960), but in the central part of the basin and areas to the southwest the water probably shoaled from depths of 3,000 to 4,000 feet early in late Pliocene time to about 900 feet at the end of the Pliocene (Natland and Rothwell, 1954, p. 40), chiefly by rapid deposition (table 1 and fig. 13).

\section{LOWER PLEISTOCENE DEPOSITS}

The lower Pleistocene is a succession of marine silt, sand, and gravel that is exposed in the southwestern block, in several of the low hills and mesas along the Newport-Inglewood zone, and in the northwest, northeast, and southeast parts of the central block. Its subsurface extent is about the same as that of the upper Pliocene sequence (fig. 14), and it is widespread beneath the lowland parts of the southwestern and central blocks.

In the Palos Verdes Hills the succession consists of marl, silt, and sand (Woodring and others, 1946). Several small exposures of soft siltstone occur about 2 miles west of Santa Monica and west of long $118^{\circ} 30^{\prime}$ W. at the northwest margin of the basin (Hoots, 1931, p. 120, loc. 311). Along the Newport-Inglewood zone, lower Pleistocene strata are exposed in the Cheviot Hills about 1.5 miles southwest of Beverly Hills (Rodda, 1957), in the Baldwin Hills (Tieje, 1926), and at Signal Hill (De Long, 1941). These exposed sections are dominantly poorly consolidated sandstone and gravel. In the Coyote Hills the exposed part consists of massive silty fine-grained sand and pebbly coarse-grained sand (C. W. Hoskins, unpub. data;
Yerkes, 1960). Along the south margin of the Puente Hills the succession is massive coarse-grained friable sand, pebbly sand, and gravel; at its base is about 10 feet of hard pebbly sandstone that contains platy white (upper Miocene) siltstone detritus (Yerkes, 1960). Near the mouth of the Santa Ana River in the southeast part of the central block are a few exposures of silt, sand, and gravel (Poland, Piper, and others, 1956). A few feet of fine-grained micaceous silty sand and conglomerate are exposed in cliffs and gullies at the northwest end of Newport Bay (Bruff, 1946, p. 236, loc. A-3133). Strata exposed in Huntington Beach Mesa that have been assigned to the lower Pleistocene (Poland, Piper, and others, 1956) are now considered to be upper Pleistocene (Valentine, 1959).

The base of the succession is exposed only in the Palos Verdes Hills, where it lies unconformably on strata of late Miocene and Pliocene age, and along the south margin of the Puente Hills, where it is evidently conformable on strata of late Pliocene age. In all exposures the top is an erosional unconformity, at which there is a local angular discordance.

The succession is as much as 600 feet thick in exposures in the Palos Verdes Hills, about 325 feet in the hills along the Newport-Inglewood zone, about 325 feet in the West Coyote oil field, about 300 feet along the south margin of the Puente Hills, and about 100 feet in the Newport Bay area. In the subsurface of the southwestern block this succession is about 1,000 feet thick; the maximum thickness is about 1,800 feet in the central block south of the West Coyote oil field.

Mollusks are common and locally abundant in lower Pleistocene strata; the exceptionally abundant mollusks in the Palos Verdes Hills are assigned an early Pleistocene age (Woodring and others, 1946, p. 98).

The mollusk assemblages of the Palos Verdes Hills have been grouped into several depth-facies associations (Woodring and others, 1946, p. 89-93). These associations indicate deposition in water that shoaled from moderate depths (300 to 600 feet) near the beginning of early Pleistocene time to shallow depths (less than 300 feet) near the end of early Pleistocene time.

\section{UPPER PLEISTOCENE DEPOSITS}

Upper Pleistocene strata are widely exposed in the Los Angeles basin. In the southwestern block they include marine terrace deposits, nonmarine terrace cover, and probably some stabilized dune deposits; along the Newport-Inglewood zone they consist of marine deposits with nonmarine cover; in the central block they form locally thick nonmarine fluvial and lagoonal deposits, but along seaward slopes of the San 
Joaquin Hills they include marine terrace deposits and nonmarine cover, and in the northeastern block nonmarine fluvial deposits. These strata extend beneath alluvial deposits in all lowland parts of the basin.

In the Palos Verdes Hills are 13 well-defined marine terraces that range in altitude from about 100 feet for the lowest to about 1,300 feet for the highest. The lowest (youngest) terrace bevels middle Miocene to early Pleistocene strata, and its platform is mantled by a thin veneer of fossiliferous coarse-grained sand and gravel (pls. 1 and 2, col. 3; Woodring and others, 1946). Slightly older marine deposits are preserved on nine of the higher terraces. The marine terrace deposits are commonly overlain by as much as 100 feet of locally derived nonmarine rubble, gravel, and sand that began to accumulate soon after emergence. Paralleling the coastline south of Santa Monica is a discontinuous 3- to 4-mile-wide belt of inactive dune deposits which consist of fine- to medium-grained sand and minor sandy silt and clay.

Marine fine- to coarse-grained sand is exposed in many of the low hills and mesas along the NewportInglewood zone and in the vicinity of Santa Monica. A thin veneer of poorly stratified nonmarine sand, silt, and soil mantles the marine deposits over much of the lowland part of the southwestern block between the Newport-Inglewood zone and the Palos Verdes Hills.

Along the northeast margin of the central block the lower part of the upper Pleistocene succession consists of brackish- or fresh-water marl and mudstone, and nonmarine pebbly sandstone; these deposits are overlain unconformably by massive earthy breccia-conglomerate, pebbly sandstone, and mudstone, which are locally crowded with platy white (upper Miocene) siltstone detritus (Yerkes, 1960). This thick succession, evidently of flood-plain origin, overlaps beds of early Pliocene to early Pleistocene age. It has been arched and eroded in the Coyote Hills; in areas along the Whittier fault zone, it is faulted and locally overturned and is overlain by relatively undeformed younger alluvial deposits.

Over much of the central block, upper Pleistocene strata include continental flood-plain deposits of gravel, sand, sandy silt, silt, and clay; these deposits generally are undeformed or slightly tilted, and they interfinger with marine deposits near the NewportInglewood zone. In the southwest part of the block the seaward slopes of the San Joaquin Hills are cut by at least eight marine terraces, the highest of which is at an altitude of nearly 1,000 feet. As in the Palos Verdes Hills, the marine terrace deposits of the San
Joaquin Hills commonly have a cover of nonmarine silt, sand, and gravel.

In the east and west parts of the northeastern block and along the south margin of the San Gabriel Mountains, upper Pleistocene strata form alluvial fan deposits that are slightly warped, faulted, and dissected. These deposits are unconsolidated, poorly sorted clay, sand, and gravel of decomposed plutonic rocks. Valley fill of similar composition probably attains a greater thickness beneath the Recent alluvium of the San Gabriel Valley.

In the Palos Verdes Hills, upper Pleistocene strata lie on a surface of erosion that bevels strata of middle Miocene to early Pleistocene age and that probably unconformably overlie lower Pleistocene strata throughout much of the southwestern block (Poland, Piper, and others, 1956, p. 17). The chiefly nonmarine and continental deposits of the central block are locally unconformable on strata as old as early Pliocene in marginal areas, but they are probably conformable on marine or nonmarine deposits of Pleistocene age in the subsurface of the central part. In marginal areas of the northeastern block the fan deposits are mostly unconformable on all older rocks.

The thickness varies greatly in different parts of the basin. In the hills and mesas along the NewportInglewood zone, the marine deposits are as much as 90 feet thick. They are less than 15 feet thick in the Palos Verdes Hills. Locally their nonmarine cover is as much as 100 feet thick where it abuts old sea cliffs. Along the inland parts of the southwestern block the marine deposits form only a thin veneer, not more than 20 feet thick. The stabilized dune deposits along the west margin of the block are as much as 200 feet thick. In the Coyote Hills the flood-plain deposits are as much as 2,300 feet thick, and in the subsurface of the central part of the basin they may locally exceed 2,500 feet. In the San Gabriel Valley, similar strata are probably as much as 4,000 feet thick.

The marine terrace deposits in the Palos Verdes Hills are evidently late Pleistocene in age because of their relations to underlying beds and the modern aspect of their fossils (Woodring and others, 1946, p. 99). Radiocarbon measurements of shell material from marine deposits on the lowest (youngest) emergent terrace give an age greater than 30,000 years (Kulp and others, 1952); other measurements on fossil algae from just west of the Palos Verdes Hills suggest that the oldest submerged terrace may have been cut between 17,000 and 24,500 years ago (Emery, 1960, p. 37). Late Pleistocene mollusk assemblages analogous to those from deposits on the lowest emergent terrace at the Palos Verdes Hills have been reported from the 
following localities: near the south margin of the Santa Monica Mountains and the Beverly Hills oil field area (Woodring, in Hoots, 1931, p. 121-122; Valentine, 1956), the Cheviot Hills (Rodda, 1957); the Baldwin Hills (Tieje, 1926), east of the Playa del Rey oil field (Willett, 1937), Signal Hill (De Long, 1941), Huntington Beach Mesa (Valentine, 1959), and Newport Bay (Bruff, 1946; Kanakoff and Emerson, 1959). Slightly different environments are suggested by assemblages of the same age in terrace deposits along the coastal part of the San Joaquin Hills. The deposits in the Santa Monica, Playa del Rey oil field, and Newport Bay areas have also yielded remains of birds and terrestrial mammals, which may relate these marine terraces to the upper part of the old alluvium in which a late Pleistocene (Rancholabrean) mammalian fauna occurs (Savage and others, 1954, p. 5557). Radiocarbon measurements on wood from a cypress tree preserved in living position and surrounded by closely packed bones in one of the collecting pits at Rancho La Brea yields an age of 13,610 to 15,620 years (Howard, 1960). Comparison of this age with the more than 30,000 years that was determined for shell material from the marine deposits on the lowest emergent terrace at Palos Verdes Hills suggests that some of the nonmarine terrace cover in the southwestern block is approximately equivalent to part of the alluvial deposits in the inland parts of the basin (Woodring and others, 1946, p. 117). Mammals from the upper part of the succession in the Coyote Hills and San Gabriel Valley areas also suggest approximate equivalence of these beds with the alluvial deposits at Rancho La Brea.

The mollusks from the marine deposits may indicate deposition in partly protected shallow water during an interglacial or adglacial interval of the late Pleistocene (Woodring and others, 1946, p. 95, 101; Valentine, 1956, p. 189-190; Kanakoff and Emerson, 1959, p. 32-33; Valentine, 1961, p. 393-400). Such marine conditions evidently existed on the lee side of an offshore island that now forms the Palos Verdes Hills and in shallow embayments to the northwest and southeast. The sea, at high stand during cutting of the lowest emergent terrace at Palos Verdes Hills, is inferred to have extended northeastward to about the present site of the synclinal axis of the central block (Valentine, 1961, p. 366).

\section{RECENT DEPOSITS}

In coastal parts of the basin where upper Pleistocene strata are marine and where late Pleistocene lowering of sea level caused erosion, most of the nonmarine materials deposited during the last cycle of alluviation are of Recent age. However, in most parts of the basin and particularly in the inland parts where nonmarine deposition has continued without interruption since late Tertiary or Pleistocene time, Recent deposits are not easily separated from upper Pleistocene strata. Along the inland margins of the central block and in the San Gabriel Valley and Chino basin, where both upper Pleistocene and Recent strata are exposed, the latter can be separated by their relatively poor consolidation and less weathered character.

The Recent deposits include sediments in modern stream channels and on their alluvial fans and flood plains, and also include sediments on beaches, in embayments, and in most dunes. The surface of the lowland plain of the central block is formed by the coalesced alluvial fans of the Los Angeles River, Rio Hondo, San Gabriel River, and Santa Ana River. From this central plain, flood-plain deposits extend up the Rio Hondo and San Gabriel River through the Whittier Narrows to form the surficial strata of the San Gabriel Valley in the central part of the northeastern block; toward the coast these deposits extend through several narrow gaps in the chain of low hills and mesas along the Newport-Inglewood zone into estuarine deposits along the shoreline.

Except in coastal areas, the deposits contain as much as 200 feet of boulder, cobble, and pebble gravel, coarse- to fine-grained sand, and silt. The coarser sediments are most abundant in the lower part. Before the tidal marshes were transformed by man into marinas and residential areas, they extended 1 to 4 miles inland from the mouths of the larger streams. These areas received alternating thin layers of marine sand, organic muck, and fluvial deposits. Along the west coast of the southwestern block between the Playa del Rey oil field and the Palos Verdes Hills a 0.2 - to 0.5 -mile-wide belt of active or recently active dunes consists of as much as 70 feet of well-sorted fine- to medium-grained sand. Beach deposits consist of fine- to medium-grained sand with minor amounts of gravel.

Several water-bearing tongues of conglomeratic sand form the basal part in ancient and existing channels of the Los Angeles, San Gabriel, and Santa Ana Rivers where these rivers cross the central lowland plain and the southwest part of the basin (Poland, Piper, and others, 1956; Poland and others, 1959; California Department of Water Resources, 1961). In areas marginal to the lowland valleys the basal beds rest unconformably on older strata.

All the highlands on the margins of the basin, especially the Santa Monica, San Gabriel, and Santa Ana Mountains and the Puente Hills, contribute debris to the deposits. 


\section{STRUCTURE OF THE BASIN}

The basement complex is deeply buried throughout much of the Los Angeles basin and the Cenozoic evolution of the basin has largely masked or destroyed evidence of the earlier structural history of the basement. This description thus deals largely with structural features in or at the base of the superjacent rocks. The configuration of the basement surface (which is necessarily inferred for much of the central and northeastern blocks) provides a graphic summary of the combined effects of the long and complex evolution of the basin (see frontispiece).

The dominant Cenozoic structural feature of the basin is the deep northwest-trending central synclinal trough (figs. 2,3 ). In the deepest part of this trough the unconformity between basement and superjacent rocks is no less than 31,000 feet below sea level. The surface of unconformity rises irregularly southeastward and crops out at altitudes as great as 3,000 feet in the northern Santa Ana Mountains, but it is not elsewhere exposed in the central block. The central block is bordered on the southwest, northeast, and northwest by other structural blocks that are separated from it and from each other by zones of faulting or flexure, along which important vertical or lateral movements occurred intermittently during deposition of the superjacent rocks. Other zones of faulting and folding divide the four principal blocks into smaller blocks having contrasting structural relief and history.

\section{SOUTHWESTERN BLOCK}

The southwestern block bounds the steep southwest flank of the central syncline, from which it is separated by the northwest-trending Newport-Inglewood zone of deformation. The southwestern block is an exposed part of the much more extensive continental borderland, most of which is beneath the Pacific Ocean. The northwest-trending Palos Verdes Hills fault zone separates the structurally elevated Palos Verdes Hills at the southwest extremity from the nearly flat low plain to the north and northeast.

Western basement underlies the superjacent rocks throughout the entire southwestern block. The low plain of the block is underlain by a buried shelflike basement surface at subsea depths of 4,000 to 14,000 feet; it has a general downward slope to the northeast (fig. 4). The basement surface has relatively open, gently plunging northwest-trending anticlinal arches and synclinal troughs. Folds in the superjacent rocks generally reflect the configuration of the basement surface, although locally, as at the Playa del Rey and Wilmington oil fields, there was moderate predepositional (pre-middle Miocene) relief at the unconform- ity. A Pliocene age for much of the folding is indicated by truncation of folded beds within Pliocene strata at the Torrance and Wilmington oil fields (Gilluly and Grant, 1949; Winterburn, 1954). Gentle warping and subsidence continue into Pleistocene time, though the major folds characteristically lack surface expression.

A conspicuous scarp along the northeast border of the Palos Verdes Hills marks a steeply southwestdipping reverse fault zone, the Palos Verdes Hills fault zone, along which Pleistocene and older strata have been strongly tilted and folded (section E-F, pl. 4). The basement surface drops across the fault zone from subsea depths of 2,000 to 4,000 feet on the upthrown southwest side to subsea depths of 5,000 to 8,000 feet on the downthrown northeast side (figs. 2 and 3). Abrupt changes in configuration of the basement surface, as well as changes in the lithology and thickness of middle Miocene, upper Miocene, and Pliocene sedimentary rock units, occur at the fault zone and suggest important components of strike-slip movement. Much of the faulting along the zone evidently occurred during Quaternary time.

The Palos Verdes Hills are formed of a large, doubly plunging northwest-trending anticline that culminates almost at the center of the hills. The basement core of the anticline is exposed at an altitude of about 1,100 feet on the northeast slope near the crest of the fold. The basement surface conforms roughly to the anticlinal structure of the overlying middle and upper Miocene strata, having been folded with them, but an abrupt southwestward thickening of the middle Miocene rocks produces some structural divergence.

Folding of the Palos Verdes Hills anticline occurred after deposition of the lower Pliocene sequence, and much of it preceded deposition of the lower Pleistocene. In middle to late Pleistocene time, after much of the anticlinal folding, the hills were uplifted at least 1,300 feet relative to present sea level, largely by movement on the Palos Verdes. Hills fault zone. Adjoining parts of the downthrown block were probably depressed 500 to 1,000 feet.

\section{NEWPORT-INGLEWOOD ZONE OF DEFORMATION}

The northwest-trending Newport-Inglewood zone of faults and folds separates the southwestern and central blocks. It is marked at the surface by low eroded scarps along recently active northwest-trending en echelon faults and by a northwest-trending chain of elongated low hills and mesas that extends from Newport Bay to Beverly Hills (fig. 5). At its northwest end the Newport-Inglewood zone terminates against or merges with the east-northeast-trending Santa 
Monica fault zone; at the southeast it passes to sea near the west margin of the San Joaquin Hills, but it evidently extends far beyond that point (Emery, 1960, p. 79).

Throughout its course the fault zone at depth is evidently the boundary between western basement on the southwest and eastern basement on the northeast. This buried basement boundary is inferred, on the basis of regional residual gravity maps and a core of questionable basement from a single well, to be directly beneath the surface trace of the zone in the Inglewood oil field (section A-B, pl. 4). North of the Inglewood oil field the basement boundary merges with or is terminated by the Santa Monica fault zone; south of the Inglewood oil field the boundary probably parallels the surface trace of the zone, but, on the basis of gravity data, it is about 1.5 miles to the northeast (section E-F, pl. 4). The orientation of structural elements of the zone has been attributed to rightlateral shearing at depth (Moody and Hill, 1956, p. 1218-1219). Right-lateral strike-slip displacement of 3,000 to 5,000 feet, as measured in oil-bearing strata of the lower sequence of the Pliocene, has been suggested for faults of the zone in the Inglewood and Long Beach oil fields (Dudley, 1954; Hill, 1954, p. 10; Poland and others, 1959, p. 75; Rothwell, 1958, p. 70). Vertical separation across faults of the zone is locally 4,000 feet at the basement surface (section E-F, pl. 4), but separation in strata of Pliocene age commonly does not exceed 1,000 feet, and at the base of the Pleistocene, 200 feet.

Late middle Miocene displacements along the fault zone are indicated by the results of drilling at the Long Beach and West Newport oil fields. An extensive tract of western basement was uplifted along the southwest side of the fault zone at that time, was exposed to erosion, and contributed detritus to middle Miocene strata northeast of the fault zone; localized uplift and erosion along the fault zone itself produced angular unconformities. Movement late in geologic time is indicated by the arching and erosion of marine upper Pleistocene and of younger nonmarine strata in the hills along the zone, and numerous seismic shocks, including the destructive Long Beach earthquake of 1933 (Richter, 1958, p. 497), attest to continuing activity.

\section{Central BLOCK}

The alluviated lowland plain, beneath which the great synclinal trough is located, rises toward the periphery of the central block into hilly or mountainous terrain-the Santa Ana Mountains and San Joaquin Hills to the east and southeast, the low hills along the
Newport-Inglewood zone to the southwest, the Santa Monica Mountains and the Elysian and Repetto Hills to the northwest, and the Coyote and Puente Hills to the northeast. All these peripheral highlands are structurally elevated margins of the central block and were relatively uplifted by Quaternary deformation.

The configuration and nature of the basement floor of the central block is largely inferred because well data are sparse and the base of the superjacent rocks is exposed only in the Santa Ana Mountains (fig. 5). The configuration of the basement surface has been projected into the central synclinal trough along reflection seismic profiles. Such projections indicate that the unconformity at the base of the superjacent rocks is at least 31,000 feet subsea in the deepest part of the central syncline. A similar depth is indicated by the relation between observed gravity and the gravitational effects of the inferred volume of sedimentary fill as calculated from rock densities measured on many hundreds of well cores (McCulloh, 1960). These calculations satisfactorily explain the conspicuous negative gravity anomaly that is nearly centered over the deepest part of the central syncline. On this basis, the unconformity can be no less than 31,000 feet subsea and may be as deep as 35,000 feet. Sparse data from the distal ends of the basin suggest that the entire central block is floored by eastern basement.

From the deepest part of the synclinal trough the basement surface rises northwestward along the axis to about 13,000 feet subsea at the northwest end of the block; southeastward this surface rises to about 15,500 feet subsea below the Santa Ana River. The southwest flank of the synclinal trough rises steeply, at an average dip of more than $40^{\circ}$, to subsea depths of 10,000 to 14,000 feet along the Newport-Inglewood zone (section $E-F, \mathrm{pl}$. 4). The northeast flank of the synclinal trough rises gently, then abruptly, to merge with a broad, gently sloping shelf. It has an average depth of about 15,000 feet subsea and is complicated by several subsidiary folds and faults. The northeast part of this shelf contains the northwest-plunging anticlinal Anaheim nose, the adjacent El Modeno fault, the west- to northwest-trending Coyote Hills uplift, and the adjoining west-plunging La Habra syncline. In its northwest part the shelf contains the gently sloping platform beneath the southern Repetto Hills and the uplift beneath the western Los Angeles oil field and Elysian Hills.

The Anaheim nose is an anticlinal feature that entirely lacks surface expression. The basement surface rises northeastward up a remarkably steep linear flank of the central synclinal trough to subsea depths 
of 9,000 to 16,000 feet along the crest of the nose. Rocks in the core of this fold are of middle Miocene age and older, upper Miocene strata lap out against the flanks, and Pliocene strata were deposited unconformably across its crest (sections $E-F$ and $F-G$, pl. 4 ; figs. 10,11 , and 14). The nose is flanked on the northeast by an inconspicuous syncline which may contain a westerly extension of the El Modeno fault and which is in turn flanked on the north by the Coyote Hills uplift. The Coyote Hills uplift is a prominent west- to northwest-trending anticlinal structure, along which the East and West Coyote, Leffingwell, and Santa $\mathrm{Fe}$ Springs oil fields have been developed. Each of these oil fields coincides with a culmination along the trend of the uplift; the culminations beneath the East and West Coyote oil fields are so young that they are reflected at the surface in low hills composed of poorly consolidated and easily eroded marine lower Pleistocene strata and younger nonmarine strata (section $B-C$, pl. 4).

Northwest of the Anaheim nose (about 2 miles west of long $118^{\circ} \mathrm{W}$.), the southwest flank of the Coyote Hills uplift coincides with the northeast flank of the central synclinal trough. This steeply dipping flank may contain the buried northwest-trending Norwalk fault. Its effects are not easily recognized in the subsurface and are not illustrated here, but this fault may have caused a low scarp along the south margin of the Coyote Hills and it has been cited as a source of earthquakes (Richter, 1958, p. 39,43). North of the Coyote Hills uplift is the elongated west-plunging La Habra syncline, below which the basement surface is downfolded to subsea depths of 18,000 to 22,000 feet. Like the Coyote Hills uplift, the La Habra syncline is expressed topographically; it appears to be young and actively growing. The northeast flank of the La Habra syncline rises at a dip of about $40^{\circ}$ to terminate along the Whittier fault zone, a steeply north-dipping reverse fault that traverses the southwest slopes of the Puente Hills (section $F-G$, pl. 4). At their west ends the Coyote Hills uplift and the La Habra syncline plunge into a faulted northeasttrending synclinal reentrant in the north flank of the central synclinal trough. West of this reentrant the basement surface rises abruptly to merge with the gently sloping platform near the Montebello, Bandini, and East Los Angeles oil fields, whence it rises further to culminate at about 5,500 feet subsea in the anticlinal feature near the western Los Angeles oil field and Elysian Hills.

The basement surface of the central synclinal trough rises eastward to the exposures of eastern basement in the Santa Ana Mountains, which are part of a broad northwest-plunging anticline that has been complexly faulted. The basement core of the mountains is unconformably overlain by Upper Cretaceous strata (pl. 2; section $C-D$, pl. 4). The Upper Cretaceous sedimentary rocks and the basement exposed on the northeast flank of the mountains are faulted against Tertiary strata of the northeastern block along the Whittier-Elsinore fault zone. The southwest flank of the mountains is complicated by subsidiary northwest-plunging anticlines and synclines, and the entire range is cut by numerous intersecting northor northwest-trending faults; the faults have diverse trends and dips but are commonly downthrown on the west. The largest and most prominent of the anticlines has a core of eastern basement at subsea depths of less than 4,000 feet that plunges northwestward to merge with the buried Anaheim nose. The youngest rocks involved in the large-scale folding are of late Pliocene age; most of the uplift of the mountains, as well as the folding and faulting, followed deposition of Pliocene rocks.

The basement surface beneath the axial part of the central synclinal trough rises gently southeastward to merge with a broad, complexly faulted anticline that underlies the central San Joaquin Hills at subsea depths of 6,000 to 13,000 feet. The lower Tertiary sedimentary rocks exposed in the core of this anticline are flanked on the east. by a broad south-trending syncline, below which the basement floor is downfolded to subsea depths greater than 13,000 feet. Upper Miocene and Pliocene strata exposed in the trough of this syncline are not preserved in other parts of the hills. The northwest-trending Shady Canyon fault transects the hills; it exhibits about 5,000 feet of separation in pre-middle Miocene rocks but is transgressed by strata of late middle Miocene age. This fault may extend northwestward under the alluvium beyond the margin of the hills along the steep southwest flank of the buried Anaheim nose. In contrast, the northwest-trending Pelican Hill fault zone was evidently active between early Miocene and late Pliocene time; its movement may include lateral separation similar to that of the nearby Newport-Inglewood zone.

The alluviated plain between the San Joaquin Hills and the Santa Ana Mountains is underlain by a southwest-sloping platform of eastern basement; the northeast part of the platform culminates below the margin of the Santa Ana Mountains at a subsea depth of about 2,500 feet and is reflected at the surface by exposures of Upper Cretaceous strata. The saddle of a narrow northwest-trending syncline at the southwest margin of the platform attains a subsea 
depth of about 8,000 feet, from which the basement surface plunges northwestward toward the central part of the basin and southeastward to merge with the broad south-plunging syncline east of the San Joaquin Hills.

\section{WHITTIER FAULT ZONE}

The Whittier fault zone and an inferred northwesterly projection form the boundary between the central and northeastern blocks (fig. 2). The fault zone is exposed for a distance of about 25 miles along the south slopes of the Puente Hills between the Whittier Narrows at the northwest end of the hills and the Santa Ana River near the southeast end. In the vicinity of the river it joins or becomes the southeast-trending Elsinore fault zone. In the Puente Hills the Whittier fault zone trends N. $65^{\circ}$ to $75^{\circ} \mathrm{W}$.; most faults of the zone $\operatorname{dip} 65^{\circ}$ to $75^{\circ} \mathrm{NE}$, and the northeast (Puente Hills) block is upthrown. Stratigraphic separation of upper Miocene rocks across the zone increases from about 2,000 feet near its southeast end to a maximum of about 14,000 feet near the center of the Puente Hills segment, northwest of which it decreases to about 3,000 feet near the Whittier Narrows. Stream courses in the central part of the segment may have been offset about 5,500 feet in a rightlateral sense. A narrow band of east-plunging drag folds extends for about 10 miles along the fault zone in the upthrown block; the plunges of these folds steepen progressively from about $35^{\circ}$ in the BreaOlinda oil field to about $75^{\circ}$ in the Whittier oil field. The offset(?) stream courses and the plunging drag folds indicate that movement on the fault includes an important component of strike slip. On the basis of this evidence, oblique net slip of about 15,000 feet may be computed for post-Miocene movement on this segment of the fault zone.

Immediately northwest of the Santa Ana River the Elsinore segment of the fault zone is vertical; southeast of the river this segment is vertical or steeply south dipping. Along this segment the southwest (Santa Ana Mountains) block is upthrown; the reversal in dip and relative vertical displacement occurs at the short southwest-trending cross fault on the south side of the zone near the Santa Ana River (figs. 2 and 3 ).

The Whittier fault zone may have been active during middle Miocene time, it was probably active during late Miocene time, and it was almost certainly active during Pliocene time. However, most of the strike-slip displacement of the central part of the fault zone probably occurred during incision of the present stream courses. Recent deformation along the fault zone is also indicated by the presence of steeply tilted and locally overturned strata of late Pleistocene and Pliocene age in the foothills just south of the zone. Remnants of old alluvial deposits are displaced at several places by faults of the zone, but young alluvial deposits at lower levels are not cut.

The Whittier fault zone is not exposed northwest of Whittier. Farther west the north boundary of the central block is represented by the steep southwest flank of the Elysian Park anticline, which is in part faulted at depth. The Elysian Park anticline with its steep southwest flank is analogous, in many respects, to the faulted anticlinal ridge adjacent to the Whittier fault zone in the Puente Hills.

\section{NORTHEASTERN BLOCK}

The northeastern block includes much of the Puente Hills in its southeast part, the San Jose Hills in its northeast part, the San Gabriel Valley in its central part, and much of the Repetto Hills in its west part. The strongly asymmetrical east-plunging Elysian Park anticline is the most prominent structural feature in the west part. The south flank of the anticline dips very steeply, in places perhaps vertically, and near its west end it is probably faulted, as indicated by the extreme structural declivity and abrupt changes in the subsurface stratigraphic section. The basement core of this fold has been penetrated by wells drilled along its crest (fig. 5); the basement surface at the west end of the fold culminates at a subsea depth of about 930 feet and plunges to a subsea depth of about 8,000 feet near the southeast end (figs. 2, 3).

The east half of the northeastern block is complex; it is floored at relatively shallow depths by eastern basement. Basement rocks are exposed at the north end of the Puente and San Jose Hills (fig. 5), and similar rocks have been penetrated by wells drilled along the anticlinal trend of the San Jose Hills at depths as great as 6,000 feet subsea. The basement surface slopes southwestward from the outcrops to subsea depths of more than 8,000 feet in the axial part of a doubly plunging northwest-trending syncline about 1.5 to 3.0 miles north of the Whittier fault zone. From this synclinal axis the basement surface rises southwestward to the crest of a faulted anticlinal ridge that underlies the structurally high part of the Puente Hills near the Whittier fault zone. This ridge culminates in an elongated faulted anticline below the northern margins of the Brea-Olinda and Sansinena oil fields where eastern basement was penetrated by numerous wells at subsea depths of 3,200 feet or more (section $F-G$, pl. 4 ; fig. 5). A 
second, analogous culmination in the basement surface probably occurs northeast of the Whittier oil field, whence the surface plunges northwestward into a structural saddle at subsea depths of 8,000 to 9,000 feet beneath the Whittier Narrows.

The configuration of the basement surface beneath the San Gabriel Valley is uncertain, but sparse well data and regional gravity studies indicate that the surface dips into a closed depression centered below the San Gabriel River about 5 miles northeast of the Whittier Narrows. Basement evidently lies at subsea depths of nearly 12,000 feet at the bottom of this depression.

The east boundary of the northeastern block is the Chino fault, which is a north-northwest-trending, steeply southwest-dipping reverse fault. Near the northwest end of its surface trace, stratigraphic separations of about 1,200 feet have been measured, but separations of 2,400 feet have been measured near the southeast end; probably the basement surface is not so greatly affected. Small drag folds that have nearly vertical axes occur in the footwall of the fault; the last movement may have included a lateral component of slip in an unknown sense. The youngest rocks cut by the fault are latest Miocene or earliest Pliocene in age, but some of the folds that are cut by the fault may be of mid-Pleistocene age.

The narrow, synclinal Chino basin just northeast of the Chino fault is probably the northwest continuation of the Temecula-Elsinore trough (Larsen, 1948, p. 122-125), a graben in Mesozoic and younger rocks that bounds the Santa Ana Mountains on the northeast. The Chino basin is floored at depths as great as 9,000 feet subsea by eastern basement. In the axial part of the syncline, middle Miocene strata rest unformably on the basement surface, which rises abruptly eastward to an extensive shelf at a subsea depth of about 1,500 feet. Progressively younger strata of late Tertiary and Quaternary ages overlap the basement rocks of the east limb of the syncline from southwest to northeast. The structurally elevated basement shelf east of the syncline is unconformably overlain by upper Miocene and younger strata; east of long $117^{\circ}$ $3712^{\prime} \mathrm{W}$. the basement crops out or is mantled by thin nonmarine deposits of Cenozoic age.

\section{SANTA MONICA-RAYMOND HILL-SIERRA MADRE-CUCAMONGA FAULT ZONE}

An east-trending zone of faults, the Santa MonicaRaymond Hill-Sierra Madre-Cucamonga fault zone, which forms the boundary between the Transverse Ranges and the Peninsular Ranges, is here described in three segments, from east to west.
The Sierra Madre-Cucamonga segment, the north boundary of the northeastern block, is an east-trending zone of high-angle reverse faults that dip northward. Granitic and metamorphic basement rocks of the San Gabriel Mountains have been uplifted many thousands of feet on the north side and juxtaposed against steeply south-dipping upper Tertiary and Quaternary strata on the south side. Movements may have occurred on this zone as early as late middle Miocene time, but Recent movements are indicated by scarps that offset depositional surfaces on alluvial fans.

The Raymond Hill segment, the northwest boundary of the northeastern block, trends about 15 miles west-southwest from its intersection with the Sierra Madre fault zone to where it transects the axial plane of the Elysian Park anticline. Throughout this distance the fault produces a topographic break, both where it offsets the alluvial surface in the east and where it juxtaposes upper Miocene sedimentary rocks and eastern basement rocks in the west. A maximum stratigraphic separation of 3,500 to 4,000 feet, upthrown on the north, is indicated for the west part of the fault; recent activity is indicated by a prominent low scarp in Quaternary alluvium.

The Santa Monica segment, with which the Raymond Hill fault merges to the west, separates the structurally elevated northwestern block from the southwestern and central blocks. This segment is nowhere as prominently expressed as the Raymond Hill fault, but many indications of its magnitude and age are available from wells. The major break is a reverse fault, which at Beverly Hills dips about $50^{\circ} \mathrm{N}$. The basement surface is upthrown on the north more than 7,500 feet on faults of the zone, the base of the upper Miocene is upthrown about 6,500 feet, the base of the lower Pliocene is upthrown about 3,000 feet, but the base of the upper Pliocene unconformably transgresses the faults (Knapp and others, 1962). Left-lateral offset is suggested by Santa Monica Slate in the core of the Elysian Hills anticline south of the fault zone and 9 miles east of the easternmost exposures of the slate north of the zone (fig. 5 ; McCulloh, 1957). Faults of the zone west of Beverly Hills locally cut marine strata of Pliocene and Pleistocene age.

\section{NORTEWESTERN BLOCK}

The northwestern block includes the eastern Santa Monica Mountains and adjoining parts of the Transverse Ranges province. The core of the eastern Santa Monica Mountains is a complexly faulted westplunging anticline of eastern basement, the flanks of 
which are unconformably overlain by superjacent rocks. Attitudes measured in the sedimentary strata conform generally to the configuration of the basement core, but conspicuous unconformities indicate that several episodes of diastrophism interrupted its accumulation of the sedimentary section. The most prominent of these episodes resulted in folding and uplift of the entire area and consequent erosion of thousands of feet of middle Miocene and older sedimentary and basement rocks from axial parts of the anticline. After subsidence and deposition of the upper Miocene rocks, renewed arching was accompanied or followed by uplift and erosion to reexpose the basement core.

Superjacent strata on the north flank of the Santa Monica Mountains dip gently to steeply northward or northeastward beneath Recent alluvium of the San Fernando Valley. The geologically diverse part of the Transverse Ranges province between the Santa Monica and San Gabriel Mountains and northwest of the Raymond Hill fault includes the Verdugo Mountains and adjacent lower hills and valleys. This tract consists of northwest-trending structural blocks. Eastern basement is exposed in some of the blocks, but in adjoining ones it is buried beneath hundreds to thousands of feet of middle Miocene to Quaternary sedimentary rocks.

\section{CONCLUSIONS}

At the onset of Late Cretaceous deposition in the Los Angeles basin, a widespread erosional surface of low relief had been formed on diverse kinds and ages of basement rocks. When this surface was transgressed and buried, it became an index of subsequent subsidence and deformation. The present structural relief of the basement floor of the basin. resulted chiefly from upper Miocene to lower Pleistocene differential sinking coupled with local uplift associated with folding and faulting. The basement surface of the deep part of the central block sank at least 9,500 feet more than at the Long Beach oil field, 12,500 feet more than beneath the south part of the Whittier Narrows, and 13,500 feet more than at Ballona Gap, southwest of the Inglewood oil field. Each of these differences in structural relief is due solely to the relatively rapid subsidence of the central deep during late Miocene and Pliocene time (pl. 2). Differential subsidence and deposition during Late Cretaceous and early Tertiary time produced some of the structural relief of the basement floor, particularly in the southeast part of the basin, where great thicknesses of Upper Cretaceous and lower Tertiary strata accumulated and are preserved.
Significant, but localized, Tertiary deformation is superposed on the great structural relief created by the differential subsidence. Such deformation produced about 4,000 feet of pre-upper Miocene throw on faults beneath the Long Beach oil field, the tremendous relief due to post-middle Miocene folding of the Anaheim nose, and pre-lower Pliocene deformation along the Coyote Hills uplift (sections $B-C$, $E-F, F-G$, pl. 4). In the San Joaquin Hills during a short interval of middle Miocene time, the Shady Canyon fault displaced early middle Miocene and older strata about 5,000 feet, diabasic rocks were intruded, the upthrown block was eroded, and the fault trace was transgressed by breccia from a western basement source.

Deformation of the Los Angeles basin has continued to modern times, as shown by warping of the Recent Series, relative uplift of highland areas, subsidence of lowland areas, and earthquakes. The Recent Series was warped or deformed at several localities along or near the Newport-Inglewood zone (Gilluly, 1949, p. 563; Parkin, 1948; Stevenson and Emery, 1958, p. 10; Fergusson and Libby, 1962, p. 113), as well as along the north margin of the Palos Verdes Hills (Woodring and others, 1946, p. 110). Relative uplift of some stations on highland areas such as the flanks of the Santa Monica Mountains, the south margin of the San Gabriel Mountains, and the south flank of the San Jose Hills has been between 4 and $6 \mathrm{~mm}$ per year for the last 25 years (Stone, 1962). Lowland parts of the basin generally continue to subside (in part owing to withdrawal of pore fluids), and the base of the Recent Series is below sea level over large parts of the basin (California Department of Water Resources, 1961). Numerous earthquakes recorded within the last 50 years in the basin area have been attributed to the Newport-Inglewood zone, the Norwalk fault (Richter, 1958), a fault exposed in the central Puente Hills (Richter and Gardner, 1960), and other faults.

\section{OIL IN THE BASIN}

\section{PRODUCTION}

In relation to its area, the Los Angeles basin is the most prolific of California's oil-producing districts and it is one of the most prolific in the world. Two fields in the basin have each produced more than 800 million barrels of oil. In 1961, the Wilmington oil field produced nearly 28 million barrels, and 18 fields had productions of more than 1 million barrels. Eighty years after the discovery of oil in the basin in 1880, this area was producing at the rate of more than 257,000 barrels per day. The cumulative production, 
TABLD 2.-Crude-oil production data and estimated reserves and ultimate recovery for the Los Angeles basin and for the State of California

[Data, in barrels, as of January 1, 1962]

\begin{tabular}{|c|c|c|}
\hline & $\begin{array}{c}\text { Los Angeles } \\
\text { basin 1 }\end{array}$ & California \\
\hline $\begin{array}{l}\text { Productlon tor } 1961 \\
\text { Cumulativo production: } \\
\quad \text { Total } \\
\quad \text { Average per proved acre } \\
\text { Estlmated reservos } \\
\text { Estlmated ultimate recovery }\end{array}$ & $\begin{array}{r}92,698,616 \\
5,035,443,286 \\
109,499 \\
1,035,203,000 \\
6,070,647,280\end{array}$ & $\begin{array}{r}288,523,356 \\
12,352,238,141 \\
57,359 \\
3,956,284,000 \\
16,308,522,141\end{array}$ \\
\hline
\end{tabular}

1 For 46 known fields; includes offshore areas of Wilmington and of Huntington Berch ofl felds and Bolmont oil feld. 2.5 miles southwest of Seal Beach oil fleld.

1 Productive areas of 45,986 and 284, 322 acres for Los Angeles basin and Caliormia rospectively, obtained from data in California Oll Fields, 1960, v. 46, no. 2, n. 110-117. All other data from 1961 Annual Review of California Crude Oil Production, Conservation Committee of California Oll Producers, Los Angeles.

and estimated reserves and ultimate recovery, for the Los Angeles basin and the State of California as of January 1, 1962, are given in table 2. These data justify the citation of the Los Angeles basin as an example of optimum geological conditions for the occurrence of oil (Barbat, 1958, p. 62).

\section{OCCURRENCE}

In the Los Angeles basin, oil is produced chiefly from lower Pliocene and upper Miocene strata; smaller amounts are recovered from middle Miocene and upper Pliocene strata and from breccia-conglomerate of schist basement rocks. Middle Miocene oil comes chiefly from the lowest producing zone in the Inglewood oil field. This oil is the only commercial production obtained in the basin today from strata of unequivocal middle Miocene age. This occurrence is unique in that the producing interval is overlain by volcanic rocks. Whether the oil is indigenous to the middle Miocene sandstones is uncertain. Oil is also produced in places from a zone of fractured, brecciated, and weathered schist as much as 400 feet thick at the top of Catalina Schist basement at the Wilmington, Playa del Rey, and El Segundo oil fields. In these fields the oil has migrated from onlapping upper Miocene strata into the older but structurally higher basement rocks. In the Yorba Linda field, some oil is produced from upper Pliocene pebble conglomerate and sandstone that occupies a channel cut into lower Pliocene strata. Table 3 shows production, estimated reserves, and estimated ultimate recovery for 46 known fields, by geologic age of reservoir rocks.

These data show that 57.8 percent of recovered oil has come from lower Pliocene rocks and 41.9 percent from upper Miocene rocks. As suggested by the respective percentages for 1961 production, 37.2 percent from the lower Pliocene and 61.8 percent from the upper Miocene, the present (early 1960's) intensive development in the northwest part of the basin may appreciably increase the proportion of ultimate recovery from the upper Miocene.

A nearly unique combination of factors and timing of events account for the productivity of the basin (Barbat, 1958). The petroliferous sediment accumulated rapidly in stagnant cool water more than 1,600 feet deep during the advancing and maximum phases of the last marine transgression (table 1 and fig. 13). The initially high organic content of the sediment was preserved because of poor circulation in the constricted basin and because of rapid filling. Great thicknesses of intercalated source and reservoir rocks include numerous permeable conduits, through which the fluid hydrocarbons were expelled by load compression toward preexisting and developing structural traps.

\section{RESERVES}

In the 80 years since oil was first discovered in the Los Angeles basin, intensive, but somewhat intermittent exploration has resulted in the present (1962) estimated ultimate recovery of more than 6 billion barrels from known fields in the onshore part of the basin. Upper Miocene and lower Pliocene strata have produced the bulk of Los Angeles basin oil and are still the most attractive sites for exploration if it is

TABLE 3.-Crude-oil production data and estimated reserves and ultimate recovery, by geologic age of reservoir rocks, for 46 known Los Angeles basin oil fields

\begin{tabular}{|c|c|c|c|c|c|}
\hline \multirow{2}{*}{ Reservoir rocks } & \multirow[b]{2}{*}{ Poolst } & \multicolumn{4}{|c|}{ Thousands of barrels } \\
\hline & & $\begin{array}{l}\text { Production } \\
\text { for } 1961\end{array}$ & $\begin{array}{l}\text { Cumulative } \\
\text { production, } \\
\text { Jan. 1, 1962 }\end{array}$ & $\begin{array}{c}\text { Estimated } \\
\text { rcserves, } \\
\text { Jan. 1, 1962 }\end{array}$ & $\begin{array}{l}\text { Estimated } \\
\text { ultimate } \\
\text { recovery }\end{array}$ \\
\hline $\begin{array}{l}\text { Late Pllocene } \\
\text { Early Pliocene } \\
\text { Late Miocene } \\
\text { Middle Mlocene } \\
\text { Pre-middlo Miocene }\end{array}$ & $\begin{array}{r}3 \\
95 \\
167 \\
2 \\
2\end{array}$ & $\begin{array}{r}701 \\
34,503 \\
57,330 \\
165 \\
0\end{array}$ & $\begin{array}{r}4,187 \\
2,913,565 \\
2,110,721 \\
6,966 \\
5\end{array}$ & $\begin{array}{r}8,396 \\
402,987 \\
622,772 \\
1,044 \\
4\end{array}$ & $\begin{array}{r}12,583 \\
3,316,552 \\
2,733,493 \\
8,010 \\
9\end{array}$ \\
\hline Total... & 269 & 92,699 & $5,035,444$ & $1,035,203$ & $6,070,647$ \\
\hline
\end{tabular}

1 Data from 1960 Annual Review of California Crude Oll Production, Conservation Committee of California Ofl Producers, Los Angeles.

2 Data from 1961 Annual Review of California Crude Oil Production, Conservation Committee of California Oil Producers, Los Angeles. 
assumed that economic incentive will continue to defray the high cost of subsurface exploration, leasing, drilling, and production in this densely populated area. The older sedimentary rocks are much less attractive, and the few tests of these strata provide little encouragement for additional exploration.

The upper Miocene and younger strata have been adequately tested in that part of the southwestern block that extends along the Newport-Inglewood zone from the Playa del Rey and Inglewood oil fields to the West Newport oil field. Local deep-pool extensions of known fields in this area are possible if suitable traps can be located. The area northwest of the Playa del Rey oil field, west of the Beverly Hills oil field, and south of the Santa Monica Mountains (fig. 5) is relatively untested and may offer considerable potential because it is almost certainly underlain by a thick section of young Tertiary strata. Offshore exploration has revealed an easterly extension of the Wilmington oil field; reserves of the undeveloped extension are estimated to be more than one billion barrels (Mayuga, 1963).

Upper Miocene and younger strata in the San Joaquin Hills, Santa Ana Mountains, Puente and Repetto Hills have been tested to varying degrees, and the results suggest that the possibility of finding appreciable new. reserves is small. The Mahala oil field, at the northeast margin of the Puente Hills, was discovered in 1955, and resulted in considerable drilling activity in the Chino basin to the northeast. Although several wells had encouraging oil shows, that area is not particularly attractive because of its attenuated stratigraphic section and its proximity to the late Miocene shoreline.

The alluviated San Gabriel basin northwest of the Puente Hills is one of the least explored areas in the Los Angeles basin. Gravity data suggest that the basement floor is about 12,000 feet subsea below the center of the San Gabriel basin, and drilling along the southern flank of the basin has indicated the presence of upper Miocene oil sands. It is not known how far northward these strata extend in the subsurface (fig. 10) nor whether traps may exist at depth. Additional geophysical work and exploratory drilling are needed to evaluate fully the petroleum potential of this area.

The deeper parts of the central synclinal area of the basin are essentially untested. The deepest well in the basin, drilled in 1959 on the southwest flank of the syncline about 3 miles northeast of the Dominguez oil feeld, was nonproductive, and regional stratigraphic and geophysical interpretations indicate that, at a total depth of almost 16,000 feet, this well did not penetrate through the Pliocene section. Because po- tential reservoir rocks are so deeply buried in this and similar areas, exploration is based chiefly on geophysical surveys, and the methods used to differentiate gravity anomalies due to structural highs from those due to excessively dense or excessively light sedimentary rocks in young formations at relatively shallow depths (see McCulloh, 1960, p. B324) assume considerable importance. The deeply buried flanks of the central syncline may possess considerable potential. Rapid downdip thickening of Pliocene strata along both flanks of the syncline suggest the possible existence of stratigraphic traps in this area, in addition to the possibility of concealed, structurally controlled traps. Successful testing for such traps depends on the accumulation and interpretation of more detailed geophysical, structural, and stratigraphic data than are now available.

Middle Miocene rocks are fairly widespread in the Los Angeles basin (fig. 9), but have been productive only in the Inglewood and Brea-Olinda oil fields where the oil may have migrated from younger strata. In the areas around the margins of the basin where middle Miocene strata have been tested, coarse clastic sediments and interbedded volcanic rocks are abundant and potential source beds are rare, except in the southern part of the basin. Moreover, porosity and permeability of the sandstone beds are low or negligible in most places. In the older Tertiary rocks the known subsurface area available for exploration becomes progressively smaller (figs. 7 and 8). In areas where these older rocks have been tested, no significant showings have been reported and potential source beds have not yet been found. However, further prospecting in these older rocks, particularly in the Eocene, may be justified in the lowland area between the San Joaquin Hills and the northwest end of the buried Anaheim nose. The section there is thick, it is in part marine, and its total porosity is considerably greater than elsewhere in the basin.

Known occurrences of Upper Cretaceous rocks are limited almost entirely to the southeast part of the Los Angeles basin (fig. 6). Exposures of thick fossiliferous dark siltstone in the Santa Ana Mountains may constitute adequate source beds for oil, but where the section has been drilled in the southeast part of the basin, porosities and permeabilities of these rocks are extremely low, and no significant shows have been found. The recently discovered and abandoned San Clemente and Cristianitos Creei oil fields, both a few miles east of the map area, are significant in that small amounts of high-gravity oil were produced from Upper Cretaceous rocks. Although these rocks have not been adequately tested throughout their known 
extent, future exploitation will require the location of traps beneath unconformities as well as of oil-saturated beds characterized by higher permeabilities and porosities.

\section{REFERENCES CITED}

Bailey, T. L., and Jahns, R. H., 1954, Geology of the Transverse Range province, southern California, in Jahns, R. H. ed., Geology of southern California: California Div. Mines Bull. 170, chap. 2, p. 83-106.

Barbat, W. F., 1958, The Los Angeles basin area, California, in A guide to the geology and oil fields of the Los Angeles and Ventura regions, Am: Assoc. Petroleum Geologists, Ann. Mtg., March 1958: p. 37-49. Also in Weeks, L. G. ed., Habitat of oil-a symposium : Tulsa, Okla., Am. Assoc. Petroleum Geologists, p. 62-77.

Bellemin, G. J., 1940, Petrology of Whittier conglomerates, southern California: Am. Assoc. Petroleum Geologists Bull., v. 24, no. 4, p. 649-671.

Bellemin, G. J., and Merriam, R. H., 1958, Petrology and ortgin of the Poway conglomerate, San Diego County, California: Geol. Soc. America Bull., v. 69, no. 2, p. 199-220.

Bruff, S. C., 1946, The paleontology of the Pleistocene molluscan fauna of the Newport Bay area, California: Californla Univ., Dept. Geol. Sci. Bull., v. 27, no. 6, p. 213-240.

California Department of Water Resources, 1961, Ground water geology, in Planned utilization of the ground water basins of the coastal plain of Los Angeles County: Callfornia Div. Water Resources Bull. 104, app. A, 191 p.

Clark, B. L., 1930, Tectonics of the Coast Ranges of middle Callfornia: Geol. Soc. America Bull., v. 41, no. 4, p. 747828.

Conrey, B. L., 1958, Depositional and sedimentary patterns of lower Pliocene-Repetto rocks in the Los Angeles basin [California], in $\mathbf{A}$ guide to the geology and oil fields of the Los Angeles and Ventura regions, Am. Assoc. Petroleum Geologists, Ann. Mtg., March 1958: p. 51-54.

Daviess, S. N., and Woodford, A. O.; 1949, Geology of the northwestern Puente Hills, Los Angeles County, California: U.S. Geol. Survey Oil and Gas Inv. Prelim. Map 83, scale 1 inch to 1,000 feet.

DeLong, J. H., Jr., 1941, The paleontology and stratigraphy of the Pleistocene at Signal Hill, Long Beach, California: San Diego Soc. Nat. History Trans., v. 9, no. 25, p. 229 250.

Driver, H. L., 1948, Genesis and evolution of Los Angeles basin, Callfornia: Am. Assoc. Petroleum Geologists Bull., v. 32, no. 1, p. 109-125.

Dudley, P. H., 1954, Geology of the Long Beach oil field, Los Angeles County, in Jahns, R. H., ed., Geology of southern California: Callfornia Div. Mines Bull. 170, map sheet 34.

Durham, D. L., and Yerkes, R. F., 1959, Geologic map of the eastern Puente Hills, Los Angeles basin, California: U.S. Geol. Survey Oil and Gas Inv. Map OM-195, scale $1: 24,000$. 1964, Geology and oil resources of the eastern Puente Hills, southern California: U.S. Geol. Survey Prof. Paper $420-B, 62$ p.

Durham, J. W., 1954, The marine Cenozoic of southern California, in Jahns, R. H., ed., Geology of southern California: Callfornia Div. Mines Bull. 170, chap. 3, p. 23-31.

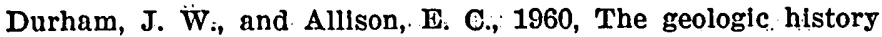
of Baja Callfornia and its marine faunas: Systematic Zoology, v. 9, no. 2, p. 47-91.
Durrell, Cordell, 1954, Geology of the Santa Monica Mountains, Los Angeles and Ventura Counties [California], in :Jahns, R. H., ed., Geology of southern California : California Div. Mines Bull. 170, map sheet 8.

Durrell, Cordell, 1956, Preliminary report on the geology of the Santa Monica Mountains, in Los Angeles Forum: Pacific Petroleum Geologist [News letter, Pacific Sec., Am. Assoc. Petroleum Geologists, Los Angeles, Calif.], v. 10, no. 4 , p. 1-3.

Eaton, G. P., 1958, Miocene volcanic activity in the Los Angeles basin [California], in A guide to the geology and oil fields of the Los Angeles and Ventura regions, Am. Assoc. Petroleum Geologists, Ann. Mtg., March 1958: p. 55-58.

Eckis, Rollin, 1928, Alluvial fans of the Cucamonga district, southern California: Jour. Geology, v. 36, no. 3, p. 224 247.

Edwards, E. C., 1934, Pliocene conglomerates of the Los Angeles basin and their paleogeographic significance: Am. Assoc. Petroleum Geologists Bull., v. 18, no. 6, p. 786-812.

Emery, K. O., 1960, The sea off southern California, a modern habitat of petroleum: New York, John Wiley \& Sons, Inc., $366 \mathrm{p}$.

English, W. A., 1926, Geology and oil resources of the Puente Hills region, southern California, with a section on the chemical character of the oil, by $P$. W. Prutzman: U.S. Geol. Survey. Bull. 768, 110 p.

Evernden, J. F., Curtis, G. H., Savage, D. E,, and James, G. T., 1964, Potassium-argon dates and the Cenozoic mammalian chronology of North America: Am. Jour. Scl., v. 262 no. 2 , p. 145-198.

Ferguson, R. N., and Willis, C. G., 1924, Dynamics of oil-field structure in southern California: Am. Assoc. Petroleum Geologists Bull., v. 8, no. 5, p .576-583.

Fergusson, G. J., and Libby, W. F., 1962, UCLA Radlocarbon dates I: Radiocarbon, v. 4, p. 109-114.

Gilluly, James, 1949, Distribution of mountain building in geologic time: Geol. Soc. America Bull., v. 60, no. 4, p. 561590.

Gilluly, James, and Grant, U. S., 4th, 1949, Subsidence in the Long Beach Harbor area, California: Geol. Soc. America Bull:, v. 60, no. 3, p. 461-529.

Hazenbush, G. C., and Allen, D. R., 1958, Huntington Beach oil field: California Oil Fields, v. 44, no. 1, p. 13-25.

Hill, M. L., 1954, Tectonics of faulting in southern California, in Jahns, R. H., ed., Geology of southern California : California Div. Mines Bull. 170, chap. 4, p. 5-13.

Hoots, H. W., 1931, Geology of the eastern part of the Santa Monica Mountains, Los Angeles County, California: U.S. Geol. Survey Prof. Paper 165-C, p. 83-134.

Howard, Hildegarde, 1960, Significance of carbon-14 dates for Rancho La Brea: S̉cience, v. 131, no. 3402, p. 712-714.

Imlay, R. W., 1963, Jurassic fossils from southern California: Jour. Paleontology, v. 37, no. 1, p. 97-107.

Irwin, W. P., 1957, Franciscan group in Coast Ranges and its equivalents in Sacramento Valley, California: Am. Assoc. Petroleum Geologists Bull., v. 41, no. 10, p. 2284-2297.

Jahnis, R. H., 1954, Geology of the Peninsular Range province, southern California and Baja California [Mexico], in Jahns, R. H., ed., Geology of southern Callfornia: Callfornia Div. Mines Bull. 170, chap. 2, p. 29-52.

Jenkins, O. P., 1938á, Geomorphic provinces of California as outlined on the new State geologic map [abs.] : Am. Assoc. Petroleum Geologists Bull., v. 22, no. 12, p. 1717. 
Jenkins, O. P., 1938b, Geologic map of California: California Div. Mines, scale $1: 500,000$.

Johnson, H. R., and Warren, V. C., 1927, Geological and structural conditions of the San Gabriel Valley region: California Div. Water Rights Bull. 5, p. 73-100.

Kanakoff, G. P., and Emerson, W. K., 1959, Late Pleistocene invertebrates of the Newport Bay area, California: Los Angeles County Mus. Contr. Sci. 31, $47 \mathrm{p}$.

Kleinpell, R. M., 1938, Miocene stratigraphy of California: Tulsa, Okla., Am. Assoc. Petroleum Geologists, 450 p.

Knapp, R. R., chm., and others, 1962, Cenozoic correlation sectlon across Los Angeles basin from Beverly Hills to Newport, California: Am. Assoc. Petroleum Geologists, Pacific Section [chart].

Kulp, J. L., Tryon, L. E., Eckelman, W. R., and Snell, W. A., 1952, Lamont natural radiocarbon measurements, [pt.] 2 : Science, v. 116, no. 3016, p. 409-414.

Kundert, C. J., 1952, Geology of the Whittier-LaHabra area, Los Angeles County, California: California Div. Mines Spec. Rept. 18, 22 p.

Larsen, E. S., Jr., 1948, Batholith and associated rocks of Corona, Elsinore, and San Luis Rey quadrangles, Southern California: Geol. Soc. America Mem. 29, 182 p.

Larsen, E. S., Jr., Gottfried, David, Jaffe, H. W., and Waring, C. L., 1958, Lead-alpha ages of the Mesozoic batholiths of western North America: U.S. Geol. Survey. Bull. 1070-B, p. 35-62.

Mallory, V. S., 1959, Lower Tertiary biostratigraphy of the California Coast Ranges: Tulsa, Okla., Am. Assoc. Petroleum Geologists, $416 \mathrm{p}$.

Mayuga; M. N., 1963, Geologic highlights-Easterly extension of the Wilmington oll field [abs.]: Am. Assoc. Petroleum Geologists Bull., v. 47, no. 9; p. 1774.

McCulloh, T. H., 1957, Simple Bouguer gravity and generalized geologic map of the northwestern part of the Los Angeles basịn, Callfornia: U.S. Geol. Survey Geophys. Inv. Map GP-149, scale $1: 48,000$.

1960, Gravity variations and the geology of the Los Angeles basin of California, in Short papers in the geological sciences: U.S. Geol. Survey Prof. Paper 400-B, p. B320-B325.

McLaughlin, R. P., and Waring, C. A., 1914, Petroleum industry of California: California Mining Bur. Bull. 69, 519 p., map folio.

Menard, H. W., 1955, Deformation of the northeastern Pacific basin and the west coast of North America: Geol. Soc. America Bull., v. 66, no. 9, p. 1149-1198.

Mendenhall, W. C., 1905, Development of underground waters in the eastern coastal-plain region of southern California : U.S. Geol. Survey Water-Supply Paper 137, 140 p.

Moody, J. D., and Hill, M. J., 1956, Wrench-fault tectonics: Geol. Soc. America Bull., v. 67, no. 9, p. 1207-1246.

Natland, M. L., and Rothwell, W. T., Jr., 1954, Fossil Foraminifera of the Los Angeles and Ventura regions, California, in Jahns, R. H., ed., Geology of southern California : Callfornia Div. Mines Bull. 170, chap. 3, p. 33-42.

Olmsted, F. H., 1950, Geology and oil prospects of western San Jose Hills, Los Angeles County, California : California Jour. Mines and Geology, v. 46, no. 2, p. 191-212.

Parkin, E. J., 1948, Vertical movement in the Los Angeles reglon, 1906-1946: Am. Geophys. Union Trans., v. 29, no. 1, p. 17-28.
Poland, J. F., Garrett, A. A., and Sinnott, Allen, 1959, Geology, hydrology, and chemical character of ground waters in the Torrance-Santa Monica area, California: U.S. Geol. Survey Water-Supply Paper 1461, 425 p.

Poland, J. F., Piper, A. M., and others, 1956, Ground-water geology of the coastal zone, Long Beach-Santa Ana area, California: U.S. Geol. Survey Water-Supply Paper 1109, $162 \mathrm{p}$.

Popenoe, W. P., 1942, Upper Cretaceous formations and faunas of southern California: Am. Assoc. Petroleum Geologists Bull., v. 26, no. 2, p. 162-187.

Popenoe, W. P., Imlay, R. W., and Murphy, M. A., 1960, Correlation of the Cretaceous formations of the Pacific Coast (United States and northwestern Mexico): Geol. Soc. America Bull., v. 71, no. 10, p. 1491-1540.

Richter, C. F., 1958, Elementary seismology: San Francisco, Calif., W. H. Freeman and Co., 768 p.

Richter, C. F., and Gardner, J. K., 1960, The Walnut, California, earthquakes of July-August, 1959: Seismol. Soc. America Bull., v. 50, no. 2, p. 181-185.

Rodda, P. U., 1957, Paleontology and stratigraphy of some marine Pleistocene deposits in northwest Los Angeles basin, California: Am. Assoc. Petroleum Geologists Bull., v. 41, no. 11, p. 2475-2492.

Rothwell, W. T., Jr., 1958, Western Los Angeles basin and Harbor area, in $\mathbf{A}$ guide to the geology and oll fields of the Los Angeles and Ventura regions, Am. Assoc. Petroleum Geologists, Ann. Mtg., March 1958: p. 65-73.

Savage, D. E., Downs, Theodore, and Poe, O. J., 1954, Cenozoic land life of southern California, in Jahns, R. H., ed., Geology of southern California: California Div. Mines Bull. 170 , chap. 3, p. $43-58$.

Schoellhamer, J. E., Kinney, D. M., Yerkes, R. F., and Vedder, J. G., 1954, Geologic map of the northern Santa Ana Mountains, Orange and Riverside Counties, California: U.S. Geol. Survey Oil and Gas Inv. Map OM-154, scale $1: 24,000$.

Schoellhamer; J. E., and Woodford, A. O., 1951, The floor of the Los Angeles basin, Los Angeles, Orange, and San Bernardino Counties, California: U.S. Geol. Survey Oll and Gas Inv. Map OM-117, scale 1 inch to 1 mile.

Schoellhamer, J. E., and Yerkes, R. F., 1961, Preliminary geologic map of the coastal part of the Malibu Beach quadrangle, Los Angeles County, California: U.S. Geol. Survey open-file map, scale $1: 12,000$.

Schoellhamer, J. E., Yerkes, R. F., and Campbell, R. H., 1962, Preliminary geologic map of the coastal part of the Point Dume quadrangle, Los Angeles County, California: U.S. Geol. Survey open-file map, scale $1: 12,000$.

Shelton, J. S., 1946, Geologic map of northeast margin of San Gabriel Basin, Los Angeles County, California: U.S. Geol. Survey Oil and Gas Inv. Prelim. Map 63, scale 1 inch to $2,000 \mathrm{ft}$.

1954, Miocene volcanism in coastal southern Callfornia, in Jahns, R. H., ed., Geology of southern California : Callfornia Div. Mines Bull. 170, chap. 7, p. 31-36. 1955, Glendora volcanic rocks, Los Angeles basin, Call. fornia: Geol. Soc. America Bull., จ. 66, no. 1, p. 45-89.

Shepard, F. P., and Emery, K. O., 1941, Submarine topography off the Callfornia coast-canyons and tectonic interpretation: Geol. Soc. America Spec. Paper 31, 171 p. 
Silberling, N. J., Schoellhamer, J. E., Gray, C. H., Jr., and Imlay, R. W., 1961, Upper Jurassic fossils from the Bedford Canyon Formation, southern California: Am. Assoc. Petroleum Geologists Bull., v. 45, no. 10, p. 1746-1748.

Silver, L. T., McKinney, C. R., Deutsch, Sarah, and Bolinger, Jane, 1963, Precambrian age determinations in the western San Gabriel Mountains, California: Jour. Geology, v. 71, no. 2, p. 196-214.

Smith, P. B., 1960, Foraminifera of the Monterey shale and Puente formation, Santa Ana Mountains and San Juan Capistrano area, California: U.S. Geol. Survey Prof. Paper 294-M, p. 463-495.

Soper, D. K., and Grant, U. S., 4th, 1932, Geology and paleontology of a portion of Los Angeles, California: Geol. Soc. America Bull., v. 43, no. 4, p. 1041-1067.

Stevenson, R. E., and Emery, K. O., 1958, Marshlands at Newport Bay, California : Allan Hancock Found. Sci. Research Occasional Paper 20, $109 \mathrm{p}$.

Stone, Robert, 1962, Geologic and engineering significance of changes in elevation revealed by precise leveling, Los Angeles area, California [abs.]: Geol. Soc. America Spec. Paper 68, p. 57-58.

Sullwold, H. H., Jr., 1960, Tarzana Fan, deep submarine fan of late Mlocene age, Los Angeles County, California: Am. Assoc. Petroleum Geologists Bull., v. 44, no. 4, p. 433-457.

Tieje, A. J., 1926, The Pliocene and Pleistocene history of the Baldwin Hills, Los Angeles County, California: Am. Assoc. Petroleum Geologists Bull., v. 10, no. 5, p. 502-512.

Valentine, J. W., 1956, Upper Pleistocene Mollusca from Potrero Canyon, Pacific Palisades, California: San Diego Soc. Nat. History Trans., v. 12, no. 10, p. 181-205.

1959, Faunule from Huntington Beach Mesa, California, [Pt.] 2 of Pleistocene molluscan notes: Nautilus, v. 73, no. 2, p. 51-57.

1961, Paleoecologic molluscan geography of the Californian Pleistocene: California Unir., Dept. Geol. Sci. Bull., จ. 34, no. 7, p. 309-442.

Vedder, J. G., 1960, Previously unreported Pliocene Mollusca from the southeastern Los Angeles basin in Short papers in the geological sciences: U.S. Geol. Survey Prof. Paper 400-B, p. B326-B328.

Vedder, J. G., and Norris, R. M., 1963, Geology of San Nicolas Island, California: U.S. Geol. Survey Prof. Paper 369 $65 \mathrm{p}$.

Vedder, J. G., Yerkes, R. F., and Schoellhamer, J. E., 1957, Geologic map of the San Joaquin Hills-San Capistrano area, Orange County, California: U.S. Geol. Survey Oil and Gas Inv. Map OM-193, scale 1:24,000.

Weaver, C. E., and others, 1944, Correlation of the marine Cenozolc formations of western North America: Geol. Soc. America Bull., v. 55, no. 5, chart 11, p. 569-598.
Willett, George, 1937, An upper Pleistocene fauna from the Baldwin Hills, Los Angeles County, California: San Diego Soc. Nat. History Trans., v. 8, no. 30, p. 379-406.

Willis, Bailey, 1938, San Andreas rift in southwestern California: Jour. Geology, v. 46, no. 8, p. 1017-1057.

Winterburn, Read, 1954, Geology of the Wilmington oil field. Los Angeles County [California], in Jahns, R. H., ed., Geology of southern California: California Div. Mines Bull. 170, map sheet 33 .

Wissler, S. G., 1943, Stratigraphic formations [relations] of the producing zones of the Los Angeles basin oil fields: California Div. Mines Bull. 118, p. 209-234.

Woodford, A. O., 1924, The Catalina metamorphic, facies of the Franciscan series: California Univ., Dept. Geol. Sci. Bull., v. 15, no. 3, p. 49-68.

1925, The San Onofre breccia; its nature and origin: California Univ., Dept. Geol. Sci. Bull., v. 15, no. 7, p. $159-280$.

- 1960, Bedrock patterns and strike-slip faulting in. southwestern California: Am. Jour. Sci., v. 258-A (Bradley volume), p. $400-417$.

Woodford, A. O., Shelton, J. S., and Moran, T. G., 1945, Geology and oil possibilities of Puente and San Jose Hills, California, 1944: U.S. Geol. Survey Oil and Gas Inv. Prelim. Map 23, scale approx. 1 inch to 1 mile.

Woodford, A. O., Moran, T. G., and Shelton, J. S., 1946, Miocene conglomerates of Puente and San Jose Hills, California: Am. Assoc. Petroleum Geologists Bull., v. 30, no. 4, p. 514-560.

Woodford, A. O., Schoellhamer, J. E., Vedder, J. G., and Yerkes, R. F., 1954, Geology of the Los Angeles basin [California], in Jahns, R. H., ed., Geology of southern California : California Div. Mines Bull. 170, chap. 2, p. 65-81.

Woodring, W. P., 1938, Lower Pliocene mollusks and echinoids from the Los Angeles basin, California, and their inferred environment: U.S. Geol. Survey Prof. Paper 190, 67 p.

Woodring, W. P., Bramlette, M. N., and Kew, W. S. W., 1946, Geology and paleontology of Palos Verdes Hills, California: U.S. Geol. Survey Prof. Paper 207, 145 p.

Woodring, W. P., and Popenoe, W. P., 1945, Paleocene and Eocene stratigraphy of the northwestern Santa Ana Mountains, Orange County, California: U.S. Geol. Survey Oil and Gas Inv. Prelim. Chart 12.

Yerkes, R. F., 1957, Volcanic rocks of the El Modeno area, Orange County, California: U.S. Geol. Survey Prof. Paper 274-L, p. 313-334.

1960, Preliminary geologic maps of the La Habra and Whittier quadrangles, Los Angeles basin, California: U.S. Geol. Survey open-file maps, scale $1: 24,000$. 